\title{
Parenting interventions for the prevention of unintentional injuries in childhood (Review)
}

\author{
Kendrick D, Mulvaney CA, Ye L, Stevens T, Mytton JA, Stewart-Brown S
}

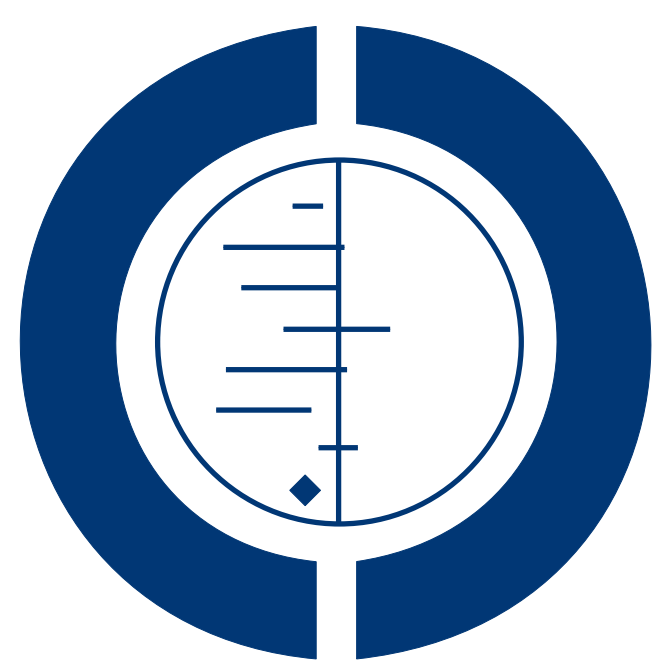

\section{THE COCHRANE COLLABORATION ${ }^{\circledR}$}

This is a reprint of a Cochrane review, prepared and maintained by The Cochrane Collaboration and published in The Cochrane Library 2013, Issue 3

http://www.thecochranelibrary.com

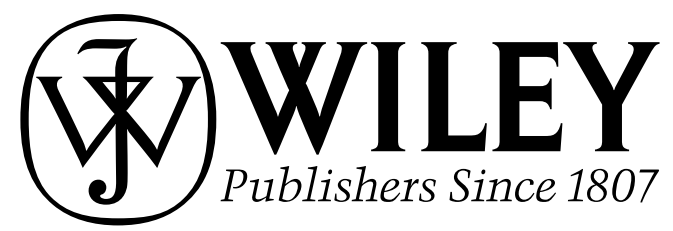

Parenting interventions for the prevention of unintentional injuries in childhood (Review)

Copyright $\odot 2013$ The Cochrane Collaboration. Published by John Wiley \& Sons, Ltd. 
TABLE OF CONTENTS

HEADER . . . . . . . . . . . . . . . . . . . . . . . . . . . . . . . . . . 1

ABSTRACT . . . . . . . . . . . . . . . . . . . . . . . . . . . . . . . . . . . . . . . . 1

PLAIN LANGUAGE SUMMARY . . . . . . . . . . . . . . . . . . . . . . . . . . . . . . . . . . . . . . . . . . . . .

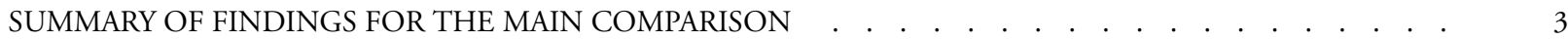

BACKGROUND . . . . . . . . . . . . . . . . . . . . . . . . . . . . . . . . . . . . . . . . . . 5

OBJECTIVES . . . . . . . . . . . . . . . . . . . . . . . . . . . . . . . . . . . . . . . . . . . . . . .

METHODS . . . . . . . . . . . . . . . . . . . . . . . . . . . . . . . . . . . . . . 5

RESUlTS . . . . . . . . . . . . . . . . . . . . . . . . . . . . . . . . . . . . . 8

Figure 1. . . . . . . . . . . . . . . . . . . . . . . . . . . . . . . . . . . . . 10

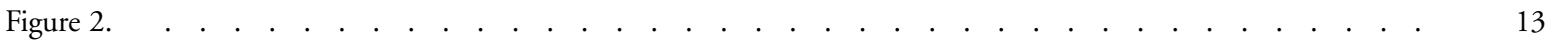

Figure 3. . . . . . . . . . . . . . . . . . . . . . . . . . . . . . . . . . . . . . 14

Figure $4 . \quad$. . . . . . . . . . . . . . . . . . . . . . . . . . . . . . . . . . . . . 15

DISCUSSION . . . . . . . . . . . . . . . . . . . . . . . . . . . . . . . . . . . . . . .

AUTHORS' CONCLUSIONS . . . . . . . . . . . . . . . . . . . . . . . . . . . . . . . . . . . . . .

ACKNOWLEDGEMENTS . . . . . . . . . . . . . . . . . . . . . . . . . . . . . . . . . 20

REFERENCES . . . . . . . . . . . . . . . . . . . . . . . . . . . . . . . . . . . . . . 20

CHARACTERISTICS OF STUDIES . . . . . . . . . . . . . . . . . . . . . . . . . . . . . . 25

DATA AND ANALYSES . . . . . . . . . . . . . . . . . . . . . . . . . . . . . . . . . . . . . . . . . . . . . . . . . . .

Analysis 1.1. Comparison 1 Intervention versus Control ( $\mathrm{n} / \mathrm{N}$ in clustered studies adjusted for clustering), Outcome 1

Medically attended or self-reported injuries - RCTs only. . . . . . . . . . . . . . . . . . . . . . . . . 58

Analysis 2.1. Comparison 2 Total HOME scores, Outcome 1 Total HOME scores. . . . . . . . . . . . . . . . . 59

ADDITIONAL TABLES . . . . . . . . . . . . . . . . . . . . . . . . . . . . . . . . . . . . . . . . . 59

APPENDICES . . . . . . . . . . . . . . . . . . . . . . . . . . . . . . . . . . . . . 68

WHAT'S NEW . . . . . . . . . . . . . . . . . . . . . . . . . . . . . . . . . . . . . . . . . . . . . .

CONTRIBUTIONS OF AUTHORS . . . . . . . . . . . . . . . . . . . . . . . . . . . . . . . . . . . 70

DECLARATIONS OF INTEREST . . . . . . . . . . . . . . . . . . . . . . . . . . . . . . . . . . . . . . . . .

SOURCES OF SUPPORT . . . . . . . . . . . . . . . . . . . . . . . . . . . . . . . . . . . . . . . . . . . . . . . . .

DIFFERENCES BETWEEN PROTOCOL AND REVIEW . . . . . . . . . . . . . . . . . . . . . . 71

INDEX TERMS . . . . . . . . . . . . . . . . . . . . . . . . . . . . . . . . . . . . . . . 72

Parenting interventions for the prevention of unintentional injuries in childhood (Review)

Copyright $\odot 2013$ The Cochrane Collaboration. Published by John Wiley \& Sons, Ltd. 


\title{
[Intervention Review] \\ Parenting interventions for the prevention of unintentional injuries in childhood
}

\author{
Denise Kendrick ${ }^{1}$, Caroline A Mulvaney ${ }^{1}$, Lily $\mathrm{Ye}^{1}$, Tony Stevens ${ }^{1}$, Julie A Mytton ${ }^{2}$, Sarah Stewart-Brown ${ }^{3}$ \\ ${ }^{1}$ Division of Primary Care, University of Nottingham, Nottingham, UK. ${ }^{2}$ Centre for Child and Adolescent Health, University of the \\ West of England at Bristol, Bristol, UK. ${ }^{3}$ Health Sciences Research Unit, Warwick Medical School, Coventry, UK \\ Contact address: Denise Kendrick, Division of Primary Care, University of Nottingham, Floor 13, Tower Building, University Park, \\ Nottingham, NG7 2RD, UK. denise.kendrick@nottingham.ac.uk.
}

Editorial group: Cochrane Injuries Group.

Publication status and date: New search for studies and content updated (conclusions changed), published in Issue 3, 2013.

Review content assessed as up-to-date: 31 January 2011.

Citation: Kendrick D, Mulvaney CA, Ye L, Stevens T, Mytton JA, Stewart-Brown S. Parenting interventions for the prevention of unintentional injuries in childhood. Cochrane Database of Systematic Reviews 2013, Issue 3. Art. No.: CD006020. DOI: 10.1002/14651858.CD006020.pub3.

Copyright (C) 2013 The Cochrane Collaboration. Published by John Wiley \& Sons, Ltd.

\begin{abstract}
A B S T R A C T
Background

Parent education and training programmes can improve maternal psychosocial health, child behavioural problems and parenting practices. This review assesses the effects of parenting interventions for reducing child injury.
\end{abstract}

\section{Objectives}

To assess the effects of parenting interventions for preventing unintentional injury in children aged under 18 years and for increasing possession and use of safety equipment and safety practices by parents.

\section{Search methods}

We searched CENTRAL, MEDLINE, EMBASE, BIOSIS Preview, PsycINFO, Sociological Abstracts, Social Science Citation Index, CINAHL, ProQuest Dissertations and Theses, ERIC, DARE, ASSIA, Web of Science, SIGLE and ZETOC. We also handsearched abstracts from the World Conferences on Injury Prevention \& Control and the journal Injury Prevention. The searches were conducted in January 2011.

\section{Selection criteria}

We included randomised controlled trials (RCTs), non-randomised controlled trials (non-RCTs) and controlled before and after studies (CBAs), which evaluated parenting interventions administered to parents of children aged 18 years and under, and reported outcome data on injuries for children (unintentional or unspecified intent), possession and use of safety equipment or safety practices (including the Home Observation for Measurement of the Environment (HOME) scale which contained an assessment of home safety) by parents. Parenting interventions were defined as those with a specified protocol, manual or curriculum aimed at changing knowledge, attitudes or skills covering a range of parenting topics.

\section{Data collection and analysis}

Studies were selected, data were extracted and quality appraised independently by two authors. Pooled relative risks (RR) were estimated using random effect models.

Parenting interventions for the prevention of unintentional injuries in childhood (Review)

Copyright @ 2013 The Cochrane Collaboration. Published by John Wiley \& Sons, Ltd. 


\section{Main results}

Twenty two studies were included in the review: 16 RCTs, two non-RCTs, one partially randomised trial which contained two randomised intervention arms and one non-randomised control arm, two CBA studies and one quasi randomised controlled trial. Seventeen studies provided interventions comprising parenting education and other support services; 15 of which were home visiting programmes and two of which were paediatric practice-based interventions. Two provided solely educational interventions. Nineteen studies recruited families who were from socio-economically disadvantaged populations, were at risk of adverse child outcomes or people who may benefit from extra support, such as single mothers, teenage mothers, first time mothers and mothers with learning difficulties. Ten RCTs involving 5074 participants were included in the meta-analysis, which indicated that intervention families had a statistically significant lower risk of injury than control families (RR 0.83, 95\% CI 0.73 to 0.94 ). Sensitivity analyses undertaken including only RCTs at low risk of various sources of bias found the findings to be robust to including only those studies at low risk of detection bias in terms of blinded outcome assessment and attrition bias in terms of follow up of fewer than $80 \%$ of participants in each arm. When analyses were restricted to studies at low risk of selection bias in terms of inadequate allocation concealment the effect size was no longer statistically significant. Several studies found statistically significant fewer home hazards or a greater number of safety practices in intervention families. Of ten studies reporting scores on the HOME scale, data from three RCTs were included in a meta-analysis which found no evidence of a difference in quality of the home environment between treatment arms (mean difference 0.57, $95 \%$ CI -0.59 to 1.72 ). Most of the studies reporting home safety practices, home hazards or composite home safety scores found statistically significant effects favouring intervention arm families. Overall, using GRADE, the quality of the evidence was rated as moderate.

\section{Authors' conclusions}

Parenting interventions, most commonly provided within the home using multi-faceted interventions are effective in reducing child injury. There is fairly consistent evidence that they also improve home safety. The evidence relates mainly to interventions provided to families from disadvantaged populations, who are at risk of adverse child health outcomes or whose families may benefit from extra support. Further research is required to explore mechanisms by which these interventions may reduce injury, the features of parenting interventions that are necessary or sufficient to reduce injury and the generalisability to different population groups.

\section{PLAIN LANGUAGE SUMMARY}

\section{Parenting programmes for the prevention of unintentional injuries in childhood}

This review looked at whether parent education and training programmes (called parenting programmes) help parents to provide a safer home environment and to reduce injuries in children. We undertook the review because there are several factors that can increase the risk of unintentional injury to children but that may be helped by parents attending parenting programmes, such as mothers' mental health and child behaviour problems. In addition, injuries are more likely to occur when parents are unable to predict a child's ability to perform tasks such as climbing furniture or opening locks. Parenting programmes may help parents develop realistic expectations of their child's behaviour for their age and stage of development. Therefore, we wanted to assess if parenting programmes reduced the risk of unintentional injuries in children and whether parents provided a safer home environment by using more safety equipment, such as stair gates, and adopted safe practices such as keeping medicines out of reach.

From searches of databases and web sites we found 22 randomised and non randomised studies that evaluated the effect of parenting programmes on childhood injuries or home safety. Fifteen of these were home visiting programmes which provided a range of support services as well as parent education or training. These were usually provided to families who were disadvantaged, whose children were considered to be at risk of poor health or those who may benefit from extra support.

We pooled the results from 10 randomised controlled trials which included a total of 5074 children and found that children from families who had received the parenting programmes had fewer injuries than those from families who had not had the programmes. We pooled the results from 3 randomized controlled trials which measured home safety using the Home Observation for Measurement of the Environment (HOME) tool. With a total of 368 children the results from these 3 studies found no difference in HOME scores between families receiving parenting programmes and those not receiving the programme. Overall, the quality of the studies was reasonable.

We conclude that parenting programmes are effective in reducing unintentional injury in children and can improve home safety, particularly in families who may be considered 'at risk', such as some teenage or single mothers. It would be worthwhile for health and social care providers to provide parenting programmes to families.

Parenting interventions for the prevention of unintentional injuries in childhood (Review)

Copyright $\odot 2013$ The Cochrane Collaboration. Published by John Wiley \& Sons, Ltd. 


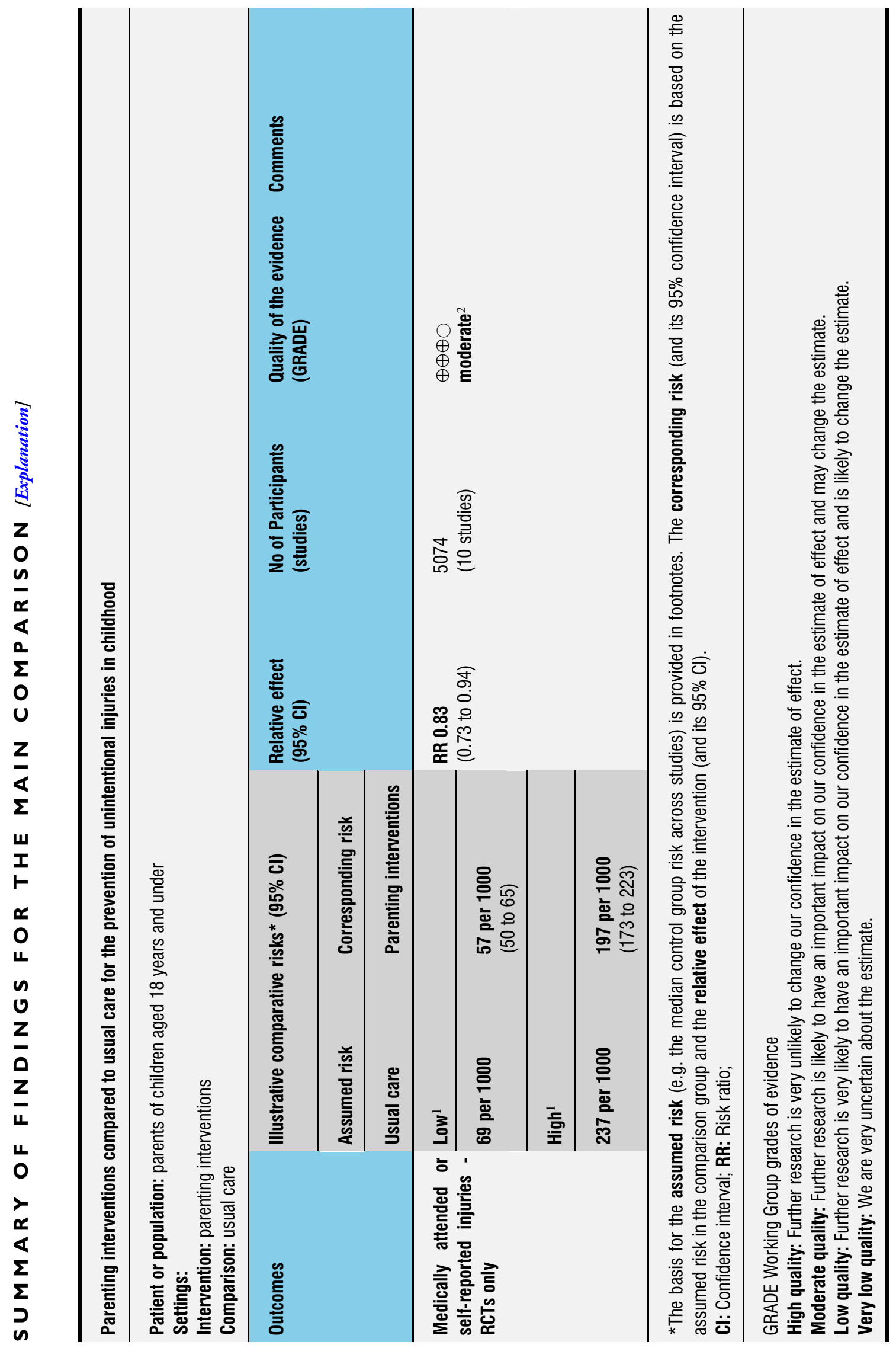

Parenting interventions for the prevention of unintentional injuries in childhood (Review)

Copyright $\odot 2013$ The Cochrane Collaboration. Published by John Wiley \& Sons, Ltd. 


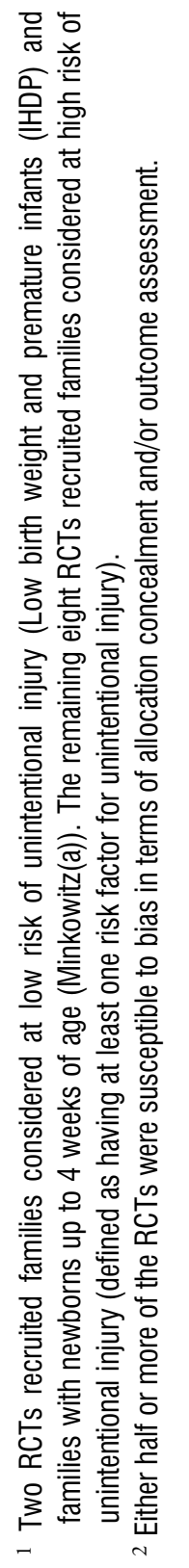

Parenting interventions for the prevention of unintentional injuries in childhood (Review)

Copyright () 2013 The Cochrane Collaboration. Published by John Wiley \& Sons, Ltd. 


\section{B A C K G ROU N D}

\section{Description of the condition}

In industrialised countries injuries are the leading cause of death in childhood, accounting for $40 \%$ all child deaths between the ages of one and 14 years (UNICEF 2001). In the UK more than 160 children die from an injury (ONS 2009) each year. In addition, more than 100,000 hospital admissions (The NHS Information Centre 2007) and more than two million attendances at accident and emergency departments resulting from child injuries occur each year (DTI 2003). There is a steep social class gradient in child injury mortality (Roberts 1997; Edwards 2006) and morbidity (Hippisley-Cox 2002); and some evidence that the gradient in injury mortality may be widening (Roberts 1996).

\section{Description of the intervention}

Parenting programmes are aimed at improving the quality of the parent-child relationship by improving parenting practices, aspects of parental functioning such as mental health, attributions and cognitions, the child's emotional and behavioural adjustment, and family functioning more generally. They can be provided in a variety of settings such as at home, in clinics and in other community venues. Several recent systematic reviews have shown that they are effective in improving behaviour problems in infants and toddlers (Barlow 2002), in 3 to 10 year old children (Barlow 2000) and also in improving maternal psychosocial health in the short term, including reducing scores measuring anxiety and depression and improving self-esteem (Barlow 2003) and self confidence. There is also evidence to show that they are effective in improving outcomes for both teenage mothers and their children (Coren 2002).

\section{How the intervention might work}

There are several mechanisms by which parenting programmes may impact on child injury rates. Firstly there is evidence that maternal psychological well being is associated with childhood unintentional injury. Higher unintentional injury rates have been found amongst children whose mothers are defined as having a psychiatric disorder (Brown 1978), suffering from depression (Beautrais 1981; Harris 1994; O’Connor 2000) or anxiety (Bradbury 1999), had experienced a higher number of life events, such as separation from their partner, recent bereavement or moving household (Beautrais 1982; O'Connor 2000) or who reported higher levels of stress (Harris 1994). A large US cohort study found depressed mothers were significantly less likely to engage in safety practices such as use of a child car seat or electric socket covers and were less likely to keep an emetic agent for the treatment of poisoning in the home (McLennan 2000). It is therefore possible that parenting programmes may be able to help re- duce childhood unintentional injury by improving maternal psychological health. Secondly, child behavioural problems including aggressive, overactive behaviour and ADHD (Miller 2004; Rowe 2004; Lam 2005) are associated with increased unintentional injury rates (Bijur 1986; Bijur 1988a; Bijur 1988b; Bussing 1996) and parenting programmes, through reducing child behavioural problems may help to reduce such injuries. Thirdly, injuries can occur when parents are unable to predict the child's ability to perform tasks such as climbing or opening locks, or parents expect them to understand and remember instructions aimed at keeping them safe from injury (Smithson 2011). Parenting programmes teach parents realistic expectations that are appropriate for a child's age and developmental stage thus potentially reducing the risk of injury (Sanders 2002; Hunt 2003). Data from a systematic review of home visiting programmes provide some evidence to support these suggested mechanisms as home visiting programmes were found to be effective in improving parenting, maternal psychosocial health, child behavioral problems and in reducing childhood unintentional injuries (Elkan 2000; Kendrick 2000). More recent work suggests that positive parenting (e.g. frequency of praise and of playing with children) is associated with a protective effect on injury rates (Schwebel 2004; Soubhi 2004). It is therefore possible that parenting programmes may help prevent childhood unintentional injury through the development of particular styles of parenting. We are therefore interested in assessing the effectiveness of parenting programmes in preventing childhood injury.

\section{Why it is important to do this review}

We were unable to find any systematic reviews examining the effect of parenting programmes on the prevention of childhood unintentional injury for the original review and thus this review was undertaken. A recent search has failed to find any more recent reviews published since our original Cochrane review.

\section{O B J E C T I VES}

The primary objective of the review is to evaluate the effectiveness of parenting programmes in preventing unintentional injury in childhood.

The secondary objective of the review is to evaluate the effectiveness of parenting programmes in increasing possession and use of home safety equipment and parental safety practices.

\section{METHODS}

\section{Criteria for considering studies for this review}




\section{Types of studies}

We included individually and cluster randomised controlled trials, non-randomised controlled trials and controlled before and after studies.

\section{Types of participants}

We included studies in which the intervention was provided for parents of children aged 18 years and under.

\section{Types of interventions}

Studies evaluating the effectiveness of individual and group-based parenting interventions were eligible for inclusion irrespective of the theoretical basis underpinning the programme. Parenting programmes are defined as interventions with a specified protocol, manual or curriculum aimed at changing knowledge, attitudes or skills covering a range of topics relevant to parenting. The control group in studies should not have a parenting intervention.

\section{Types of outcome measures}

Studies were eligible for inclusion if they reported the primary outcomes:

- self-reported or medically attended unintentional injury or injury of unspecified intent;

or secondary outcomes:

- possession and use of home safety equipment,

- safety practices (for example, storage of hazardous objects and substances, use of baby walkers, unsafe hot water temperature, etc and composite measures of safety practices including the Home Observation for Measurement of the Environment inventory. The Infant-Toddler HOME inventory, designed for use with children aged 0 to 3 years, consists of 6 subscales: emotional and verbal responsivity of the primary caregiver (items 1-11); avoidance of restriction and punishment (items 12-19); organisation of the physical and temporal environment (items 20-25) including "the child's play environment appears safe and free of hazards"; provision of appropriate play materials (items 26-34); parental involvement with the child (items 35-40) and opportunities for variety in daily stimulation (items 40-45) (Caldwell 2003; Totsika 2004). A higher score indicates a more appropriate home environment for child development.

Intentional injury outcomes were excluded as these are the focus of another Cochrane review (Barlow 2006). Parent training interventions for children with $\mathrm{ADHD}$ which are the subject of a protocol for a Cochrane review (Zwi 2011) were included as injury is not an outcome listed in the protocol.

\section{Search methods for identification of studies}

The search strategy was used to identify randomised and nonrandomised studies using terms to identify parenting programmes, and injuries, safety equipment and safety practices.

\section{Electronic searches}

We searched the following databases, without any language restriction, from the date of inception to January 2011 (from 2005 to 2011 for the update):

- Cochrane Central Register of Controlled Trials

(CENTRAL) issue 1, 2011;

- Cochrane Database of Systematic Reviews (CDSR);

- MEDLINE (Ovid SP) 1950 to January 2011;

- EMBASE (Ovid SP) 1980 to January 2011;

- BIOSIS Previews (was Biological Abstract) 1969 to January 2011;

- PsycINFO (Ovid) 1806 to January;

- Sociological Abstracts (was Sociofile) (CSA) 1952 January 2011;

- CINAHL (EBSCO) 1982 to January 2011;

- ProQuest Dissertations and Theses (was Dissertation Abstracts) 1743 to January 2011;

- ERIC 1966 to January 2011;

- Database of Abstracts of Reviews of Effectiveness 1994 to January 2011;

- ASSIA 1987 to January 2011;

- ISI Web of Science: Social Sciences Citation Index (SSCI) 1970 to January 2011,

- ISI Web of Science: Conference Proceedings Citation Index-Social Science \& Humanities (CPCI-SSH) -1990 to January 2011;

- SIGLE (ceased March 2005);

- ZETOC 1993 to January 2011.

We also searched a range of websites including:

- the Injury Prevention Research Center at the Centers for Disease Control (USA) (http://www.cdc.gov/injury/. Searched December 2010)

- the National Institute for Health and Clinical Excellence (NICE) (http://www.nice.org.uk/. Searched December 2010)

- Public Health website (UK) ( http://www.dh.gov.uk/en/ index.htm. Searched December 2010)

- the Children's Safety Network (USA) (http:// www.childrenssafetynetwork.org/. Searched December 2010)

- the International Society for Child and Adolescent Injury Prevention (International) (http://iscaip.net/iscaip/. Searched December 2010)

- the Child Accident Prevention Trust (UK) (http:// www.capt.org.uk/. Searched December 2010)

- the Injury Control Resource Information Network (USA) (http://www.injurycontrol.com/icrin/research.htm. Searched December 2010) 
- the National Injury Surveillance Unit (Australia) ( http://

www.nisu.flinders.edu.au/. Searched December 2010)

- the Injury Prevention Web and SafetyLit (USA) (http://

www.safetylit.org/. Searched December 2010)

- Barnado's Policy and Research Unit (UK) (http://

www.barnardos.org.uk/what_we_do/policy_research_unit.htm.

Searched December 2010)

- NCH (UK) (http://www.actionforchildren.org.uk/.

Searched December 2010)

- National Children's Bureau (UK) ( http://www.ncb.org.uk/. Searched December 2010)

- Children in Wales (UK) (http://

www.childreninwales.org.uk/index.html. Searched December 2010)

- Homestart (UK) (http://www.home-start.org.uk/

homepage. Searched December 2010)

\section{Searching other resources}

We handsearched abstracts from the $1^{\text {st }}$ to $10^{\text {th }}$ World Conferences on Injury Prevention and Control and the table of contents for Injury Prevention from first publication to January 2011. We also handsearched reference lists of articles identified through database searches and bibliographies of systematic and non-systematic reviews. As injuries, safety equipment or safety practices may have been secondary outcome measures in studies, we attempted to contact authors of studies excluded because of the outcomes they reported to ascertain if they had measured, but not reported, outcomes relevant for our review.

To identify unpublished studies we searched the following sources:

- The Cochrane Library

- Current Controlled Trials

- National Research Register (NRR) (up to September 2007, the date of its closure)

- UK Clinical Research Network Study Portfolio.

There were no restrictions by language or publication status.

\section{Data collection and analysis}

\section{Selection of studies}

A two stage screening process was undertaken. Two reviewers independently scanned titles and abstracts of articles to identify articles to retrieve in full. Where there was disagreement between reviewers, a decision was made by a third reviewer. The full article was retrieved for those articles retained at this stage. Two reviewers independently assessed selected articles using a standard form listing inclusion criteria, with disagreements dealt with by referral to a third reviewer.

\section{Data extraction and management}

Data extraction was undertaken independently by pairs of reviewers (DK, CM, TS, LY) using a pre-tested data extraction form. For each study we extracted data on the following: age of participants; country where study was set; whether participants were considered at risk of non-accidental injury; type of intervention (for example, group based, individual); aim of intervention in terms of changing parenting knowledge, parenting attitudes or parenting skills and in preventing non-accidental injury, improving child behaviour and improving maternal psychosocial health; who delivered the intervention and where; the number of contacts and sessions; length of each contact/session and over what time period. Data on the study population were extracted, such as living in deprived areas, age of mother, years/level of maternal education; single parenthood and ethnic group. We also extracted data on study design, the number of subjects recruited to with intervention or control groups, the number of intervention group parents who did not receive the intervention and the number completing the study.

In terms of the primary outcomes (medically attended injuries) and secondary outcomes (possessions and use of safety equipment) of interest, we extracted data on the number of participants in the intervention or control group, the number with the outcome of interest. For the primary outcome this data was extracted at either child, family or cluster level, as appropriate to the study design. Where data were presented as the mean number of injuries over a period of time $(\mathrm{m})$ we estimated the probability of a participant not having an injury assuming the occurrence of injuries followed a Poisson distribution using $\mathrm{e}^{m}{ }^{m}$ and from this estimated the number of children who did and who did not experience at least one injury".

For the secondary outcome HOME score, we extracted the mean score and SD for the intervention and control groups. For cluster randomised controlled trials we extracted the ICCs for the primary and secondary outcome measures if reported. We also extracted data on study outcomes we extracted data on the time period over which outcomes were measured.

If key data was not available in the published reports, we contacted study authors to obtain missing information.

\section{Assessment of risk of bias in included studies}

Critical appraisal of included studies was undertaken independently by two reviewers covering the following sources of bias for RCTs:

- random sequence generation (selection bias)

- allocation concealment (selection bias)

- blinding (performance bias and detection bias)

- blinding of participants and personnel (performance bias)

- blinding of outcome assessment (detection bias)

- incomplete outcome data (attrition bias)

- selective reporting (reporting bias)

- other bias

Parenting interventions for the prevention of unintentional injuries in childhood (Review) 
The following sources of bias were assessed for non-randomised studies:

- participant selection (selection bias)

- blinding (performance bias and detection bias)

- blinding of participants and personnel (performance bias)

- blinding of outcome assessment (detection bias)

- incomplete outcome data (attrition bias)

- selective reporting (reporting bias)

- risk of bias due to confounding: Was there an assessment of the distribution of confounders between treatment arms? If so, do treatment arms appear similar in terms of confounders?

- other bias.

Reviewers gave a brief description of possible sources of each type of bias and rated the risk of bias as high risk, low risk, unclear or unknown risk. Disagreement between reviewers was dealt with by referral to a third reviewer.

\section{Measures of treatment effect}

Pooled relative risks and $95 \%$ confidence intervals have been used for binary outcome measures and mean differences and 95\% confidence intervals for continuous outcome measures.

\section{Unit of analysis issues}

We adjusted the reported treatment effect in cluster allocated studies reporting binary outcomes as numerators and denominators, unadjusted for clustering, using the intra class correlation coefficient (ICC) of the study if available, otherwise using the ICC of similar cluster randomised studies. We adjusted numerators and denominators using the design effect which was calculated from the ICC and the average cluster size.

\section{Dealing with missing data}

We assessed missing data and dropouts for each included study and have reported the number of participants who are included in the final analysis as a proportion of all participants in each study. Reasons for missing data have been provided in the narrative summary, where available, and we have assessed the extent to which the results of the review could be altered by the missing data. Assessment was also made of the extent to which studies have conformed to an intention-to-treat analysis and the effects of this on the results.

\section{Assessment of heterogeneity}

Statistical tests of homogeneity were undertaken using chi-square tests (with significance defined as a $\mathrm{P}$ value of $<0.1$ ) and the Isquared statistic. The I-squared statistic describes the percentage of total variation across studies due to heterogeneity rather than chance. A value of $0 \%$ indicates no observed heterogeneity, and larger values show increasing heterogeneity; substantial heterogeneity is considered to exist when I-squared $>50 \%$ (Higgins 2005). Pooled relative risks (RR) and 95\% confidence intervals (CI) have been estimated for the binary outcome of occurrence of at least one self-reported or medically attended injury, using random effect models to allow for heterogeneity.

\section{Assessment of reporting biases}

Publication bias was assessed for the primary analysis using a funnel plot and Egger's test (using Stata version 11).

\section{Data synthesis}

Pooled relative risks and 95\% CI were estimated for occurrence of at least one self reported or medically attended injury using data from included RCTs. Pooled mean differences and 95\% CI were estimated for HOME scale scores using data from included RCTs. Random-effect models were used to allow for and quantify the degree of statistical heterogeneity present between individual studies. Where there were insufficient clinically homogenous studies to combine in a meta-analysis or where findings were from non RCTs, their results were combined in a narrative review. We produced a "summary of findings table" for the primary outcome of injuries and assessed the evidence using GRADE.

\section{Subgroup analysis and investigation of heterogeneity}

No sub-group analyses have been undertaken.

\section{Sensitivity analysis}

Sensitivity analyses have been undertaken including only RCTs considered to be at low risk of selection bias in terms of adequate allocation concealment, detection bias in terms of blinded outcome assessment and attrition bias due to follow up of fewer than $80 \%$ of participants in each arm. Sensitivity analyses have also been undertaken by (a) excluding one study where there was some uncertainty as to the extent to which the intervention was based on a protocol, manual or curriculum (Fergusson 2005) and (b) including longer term (seven years), but less complete follow up data from one study (Johnson 2000) whose short term follow up data (Johnson 1993) were included in the main analysis. Finally one study reported a range of injury types (bruises, burns, scratches and unspecified injury separately) and the most commonly reported outcome (bruises) was chosen for inclusion in the main analysis with sensitivity analyses undertaken for the other outcomes (Armstrong 2000).

\section{R E S U L T S}




\section{Description of studies}

See: Characteristics of included studies; Characteristics of excluded studies.

Twenty two studies from 30 articles were included in the review and are described in the table 'Characteristics of included studies' (Characteristics of included studies; Table 1). The process of study selection is documented in Figure 1 (Figure 1). Several authors report results from the same study at different follow-up time points in separate papers: two papers presented results from one RCT at child's first birthday (Johnson 1993) and at seven years follow up (Johnson 2000), two papers presented results from one RCT at 12 (Barlow 2007) and 36 months (Barlow 2008) post natally, two papers presented results from one RCT at two years (Olds 1986) and at 25 to 50 months follow-up (Olds 1994), two papers presented results from one RCT at four months (Armstrong 2000) and at 18 months (Fraser 2000) postnatally, two papers presented results from a non-RCT at one week and three months postpartum (Johnston 2004) and at 30 months postpartum (Johnston 2006) and two papers presented results from one RCT at two years (Duggan 1999) and three years (Duggan 2004) post recruitment. Similarly, several authors report results from the same study in more than one paper: results from one RCT collected at the time of the child's second birthday are presented in two papers (Caldera 2007)(Duggan 2007), results from one RCT collected at 1, 12 and 24 months post partum are presented in two papers (Kemp 2008; Kemp 2011) and results from one RCT collected annually on the child's birthday for five years are presented in two papers (St Pierre 1999) (Goodson 2000). One paper presents the results from both an RCT (Minkovitz 2003 (a)) and a CBA (Minkovitz 2003 (b)). 
Figure I. Quorum flow chart detailing process of study selection for all studies included in the review.

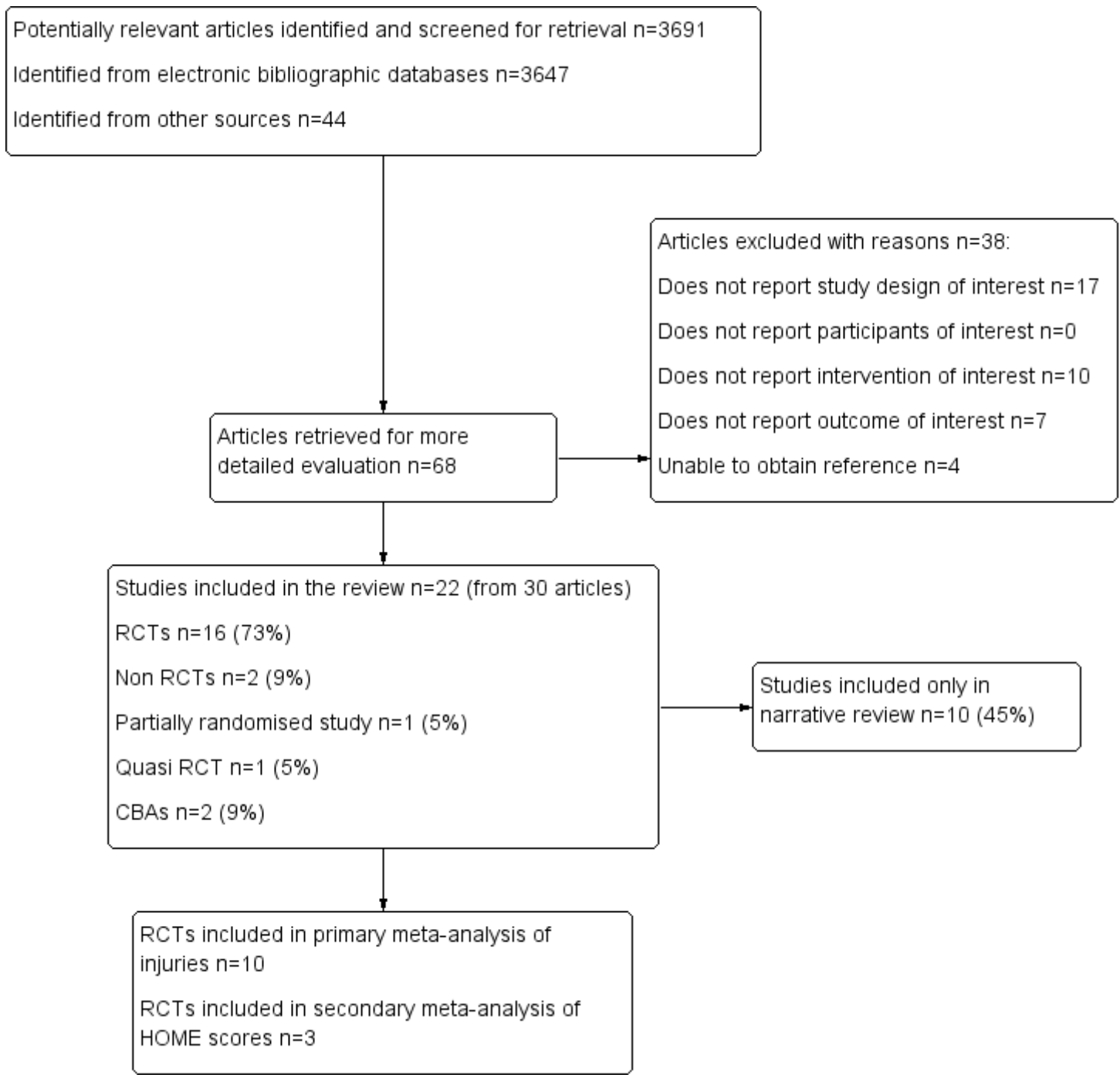

\section{Types of studies}

Sixteen (73\%) included studies were RCTs (Gutelius 1977; Olds 1986; IHDP 1990; Feldman 1992; Johnson 1993; Kitzman 1997; Duggan 1999; St Pierre 1999; Armstrong 2000; Koniak-Griffin 2003; Llewellyn 2003; Minkovitz 2003 (a); Fergusson 2005; Barlow 2007; Caldera 2007; Kemp 2011), two (9\%) were nonRCTs (Johnston 2004; Culp 2007), one (5\%) was a partially randomised study with two randomised intervention arms and one non-randomised control arm (Larson 1980), two (9\%) were CBA studies (Emond 2002; Minkovitz 2003 (b)) and one (5\%) was a quasi RCT (Hardy 1989). Four studies used clustered allocation (Emond 2002; Minkovitz 2003 (b); Johnston 2004; Culp 2007). Thirteen studies (59\%) were from the USA, three from Australia
(14\%), two (9\%) each from Canada and England, and one (5\%) each from Ireland and New Zealand.

\section{Types of participants}

Fifteen of the studies recruited socio-economically disadvantaged participants (Gutelius 1977; Larson 1980; Olds 1986; Hardy 1989; Johnson 1993; Kitzman 1997; Duggan 1999; St Pierre 1999; Armstrong 2000; Emond 2002; Koniak-Griffin 2003; Fergusson 2005; Barlow 2007; Caldera 2007; Kemp 2011), five of these studies specifically recruited participants considered to be at risk of child abuse or neglect (Olds 1986; Duggan 1999; Armstrong 2000; Barlow 2007; Caldera 2007) and two specifi- 
cally recruited young mothers (age 15 to 19 years of age) (Gutelius 1977; Koniak-Griffin 2003). Two studies recruited participants with a learning disability (Feldman 1992; Llewellyn 2003), one study recruited mothers who were considered at risk of poorer coping as a parent (Kemp 2011), one recruited mothers of low birth weight premature infants (IHDP 1990), two studies recruited first time mothers ( Johnson 1993; Culp 2007), and three studies recruited consecutive newborns from a range of paediatric practices (Minkovitz 2003 (a); Minkovitz 2003 (b); Johnston 2004).

\section{Types of interventions}

Seventeen studies evaluated multi-faceted home visiting programmes aimed at improving a range of child and often maternal health outcomes (Gutelius 1977; Larson 1980; Olds 1986; Hardy 1989; IHDP 1990; Johnson 1993; Kitzman 1997; Duggan 1999; St Pierre 1999; Armstrong 2000; Emond 2002; KoniakGriffin 2003; Fergusson 2005; Barlow 2007; Caldera 2007; Culp 2007; Kemp 2011). Three studies evaluated paediatric practicebased multi-faceted interventions, aimed at improving a range of child health outcomes, all of which included some home visits (Minkovitz 2003 (a); Minkovitz 2003 (b); Johnston 2004), but these were not the main method of delivery of the intervention. Two studies provided solely educational interventions in the home (Feldman 1992; Llewellyn 2003). The 20 studies evaluating multi-faceted interventions provided both parenting education and a range of other support services included 12 which helped the family with solving a variety of problems (Kitzman 1997; Larson 1980; IHDP 1990; Johnson 1993; St Pierre 1999; Emond 2002; Minkovitz 2003 (a); Minkovitz 2003 (b); Johnston 2004; Fergusson 2005; Barlow 2007; Kemp 2011) and 12 facilitated access to child health (Gutelius 1977; Larson 1980; Olds 1986; IHDP 1990; Kitzman 1997; Duggan 1999; Minkovitz 2003 (a); Minkovitz 2003 (b); Johnston 2004; Caldera 2007) or other community services (Olds 1986; Hardy 1989; Duggan 1999; Armstrong 2000).

All studies provided the intervention to individual parents but in addition four studies provided opportunities for peer support from other parents (St Pierre 1999; Minkovitz 2003 (a); Minkovitz 2003 (b); Kemp 2011) and one for enhanced informal support from family and friends (Olds 1986), and five studies provided parenting education to groups of parents (Gutelius 1977; IHDP 1990; St Pierre 1999; Koniak-Griffin 2003; Johnston 2004) which as a consequence would also provide opportunities for peer support. One of the two studies that provided solely educational interventions (Llewellyn 2003) included a control group that received home visits in which the visitor discussed parents' experiences of raising their children but without the educational intervention, so allowing the effect of the home visit as opposed to that of the education to be assessed (Llewellyn 2003).

\section{Types of outcome measures}

Sixteen studies reported medically attended or self-reported injury (Gutelius 1977; Larson 1980; Olds 1986; Hardy 1989; IHDP 1990; Johnson 1993; Kitzman 1997; Duggan 1999; Armstrong 2000; Emond 2002; Koniak-Griffin 2003; Minkovitz 2003 (a); Minkovitz 2003 (b); Fergusson 2005; Caldera 2007; Culp 2007). Of these, one did not provide numerators and denominators (Emond 2002). Data from one study (IHDP 1990) for use in the meta-analysis was taken from that reported in a systematic review (Roberts 1996b). Data from another study (Culp 2007) was calculated from non published data. Kitzman (Kitzman 1997) reports the incidence of five types of hospital encounters for injuries and ingestions including number of outpatient visits and number of hospitalizations; data on total number of health care encounters for injures and ingestions was used in the meta-analysis for this review.

One study presented maternal reports of medically attended injuries in the first and second years of life (Duggan 1999) and a separate paper from the same study reported hospitalisations in the first three years of life (Duggan 2004), which are not mutually exclusive outcomes. Data from the first two years of life were included in the meta-analysis as the number of events for this outcome was higher.

Seven studies reported a range of safety outcomes including use of socket covers (Emond 2002; Minkovitz 2003 (a); Minkovitz 2003 (b); Johnston 2006), stair gates (Emond 2002; Johnston 2006), lowering hot water heater temperature (Minkovitz 2003 (a); Minkovitz 2003 (b); Culp 2007), use of cabinet locks and knowing the number to call if a child ingests harmful substances (Minkovitz 2003 (a); Minkovitz 2003 (b); Johnston 2006), accessibility of poisons (Olds 1986), stickers on poisonous substances (Minkovitz 2003 (a); Minkovitz 2003 (b)), having a functional smoke alarm (Minkovitz 2003 (a); Minkovitz 2003 (b)), and sleep safety practices (Feldman 1992; Johnston 2004). Two studies reported a range of home hazards using different tools (Olds 1986; Llewellyn 2003) and one study reported use of a home safety index at 3 and 30 months (Johnston 2004; Johnston 2006) based on the presence of a functioning smoke alarm, regular and correct use of a car seat, absence of, or safe storage of firearms in the house and for the 3 month data collection only, the use of safe sleep practices (Johnston 2004).

Ten studies (Larson 1980; Olds 1986; Kitzman 1997; Duggan 1999; St Pierre 1999; Armstrong 2000; Koniak-Griffin 2003; Barlow 2007; Caldera 2007; Kemp 2011) measured the quality of the home environment using the HOME (Home Observation for Measurement of the Environment) inventory; one subscale of which measures organisation of the environment in relation to child development and safety. Of the ten studies, a total of eight reported total HOME scores, three reported "organisation of the home environment" subscale scores and two reported scores for subscales that were irrelevant to the outcomes of this review (Table 2). The HOME score was most commonly measured at 12 
months. One study measured the quality of the home environment using the Massachusetts Home Safety Questionnaire (Culp 2007).

\section{Risk of bias in included studies}

Studies were assessed for quality using the criteria described in the table 'Characteristics of included studies' (Characteristics of included studies). In terms of selection bias, 10 (63\%) of the 16 RCTs had a low risk due to adequate random sequence generation and seven (44\%) due to adequate allocation concealment (Figure 2; Figure 3). While 15 (94\%) of the 16 RCTs were judged to be at high risk of performance bias, only five (31\%) were judged to be at high risk of detection bias. Six (38\%) of the 16 RCTs had a high risk of attrition bias and 5 (31\%) were judged as being at high risk of selective reporting bias. 
Figure 2. Risk of bias summary: review authors' judgements about each risk of bias item for each included study.

\begin{tabular}{|c|c|c|c|c|c|c|c|c|c|}
\hline & 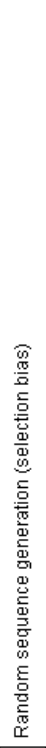 & 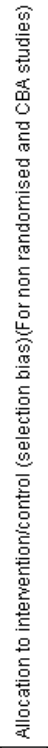 & 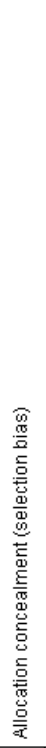 & 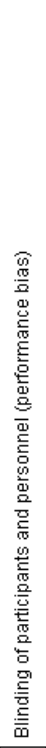 & 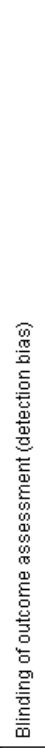 & 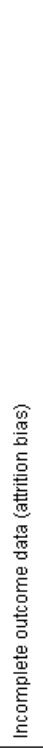 & 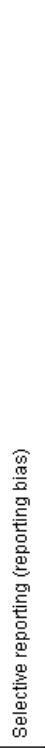 & 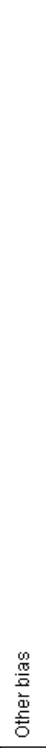 & 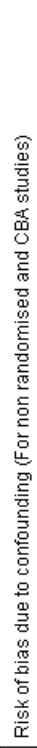 \\
\hline Armstrong 2000 & $\odot$ & & + & $\odot$ & + & + & $\odot$ & + & \\
\hline Barlow 2007 & $?$ & & $\odot$ & $\odot$ & $\odot$ & $\odot$ & $\odot$ & $\odot$ & \\
\hline Caldera 2007 & $\odot$ & & $?$ & $\odot$ & $\odot$ & $\odot$ & $\odot$ & $\odot$ & \\
\hline Culp 2007 & & $?$ & & - & $?$ & $\odot$ & + & $\odot$ & + \\
\hline Duggan 1999 & $\odot$ & & + & $\Theta$ & $\odot$ & $\odot$ & $\odot$ & $\odot$ & \\
\hline Emond 2002 & & - & & $\odot$ & $?$ & + & $\odot$ & $?$ & $\Theta$ \\
\hline Feldman 1992 & $?$ & & $\odot$ & - & + & + & $\odot$ & $?$ & \\
\hline Fergusson 2005 & $\odot$ & & $?$ & - & $\odot$ & $\odot$ & $\odot$ & $\odot$ & \\
\hline Gutelius 1977 & $?$ & & $?$ & & $\odot$ & $\odot$ & - & $?$ & \\
\hline Hardy 1989 & & $\odot$ & & $\odot$ & $?$ & $\odot$ & $\odot$ & $\odot$ & $\odot$ \\
\hline IHDP 1990 & $?$ & & $?$ & 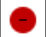 & $\odot$ & $\odot$ & $\odot$ & $?$ & \\
\hline Johnson 1993 & $\odot$ & & $\oplus$ & 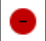 & $\odot$ & $\odot$ & $\odot$ & $?$ & \\
\hline Johnston 2004 & & $?$ & & & $?$ & $\odot$ & $\odot$ & $\odot$ & $\Theta$ \\
\hline Kemp 2011 & $?$ & & + & & $\theta$ & $\odot$ & 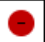 & + & \\
\hline Kitzman 1997 & $\odot$ & & $\odot$ & 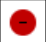 & $\odot$ & $\oplus$ & $\odot$ & $\odot$ & \\
\hline Koniak-Griffin 2003 & $\odot$ & & $?$ & ? & $\odot$ & $\odot$ & $\odot$ & $\odot$ & \\
\hline Larson 1980 & $?$ & $?$ & $?$ & $\odot$ & 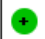 & $\odot$ & 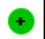 & $?$ & $\odot$ \\
\hline Llewellyn 2003 & $\odot$ & & $?$ & $\odot$ & $\odot$ & $\odot$ & $?$ & $?$ & \\
\hline Minkovitz 2003 (a) & $\odot$ & & $\odot$ & $\odot$ & $?$ & $\odot$ & $\odot$ & $\odot$ & \\
\hline Minkovitz 2003 (b) & & $?$ & & & $?$ & $\odot$ & $\odot$ & $\odot$ & \\
\hline Olds 1986 & $\odot$ & & $\odot$ & $\Rightarrow$ & $\odot$ & $\odot$ & - & $\odot$ & \\
\hline St Pierre 1999 & ? & & $?$ & $\odot$ & $?$ & $\odot$ & $\odot$ & $\odot$ & \\
\hline
\end{tabular}


Figure 3. Risk of bias graph: review authors' judgements about each risk of bias item presented as percentages across all 22 included studies.

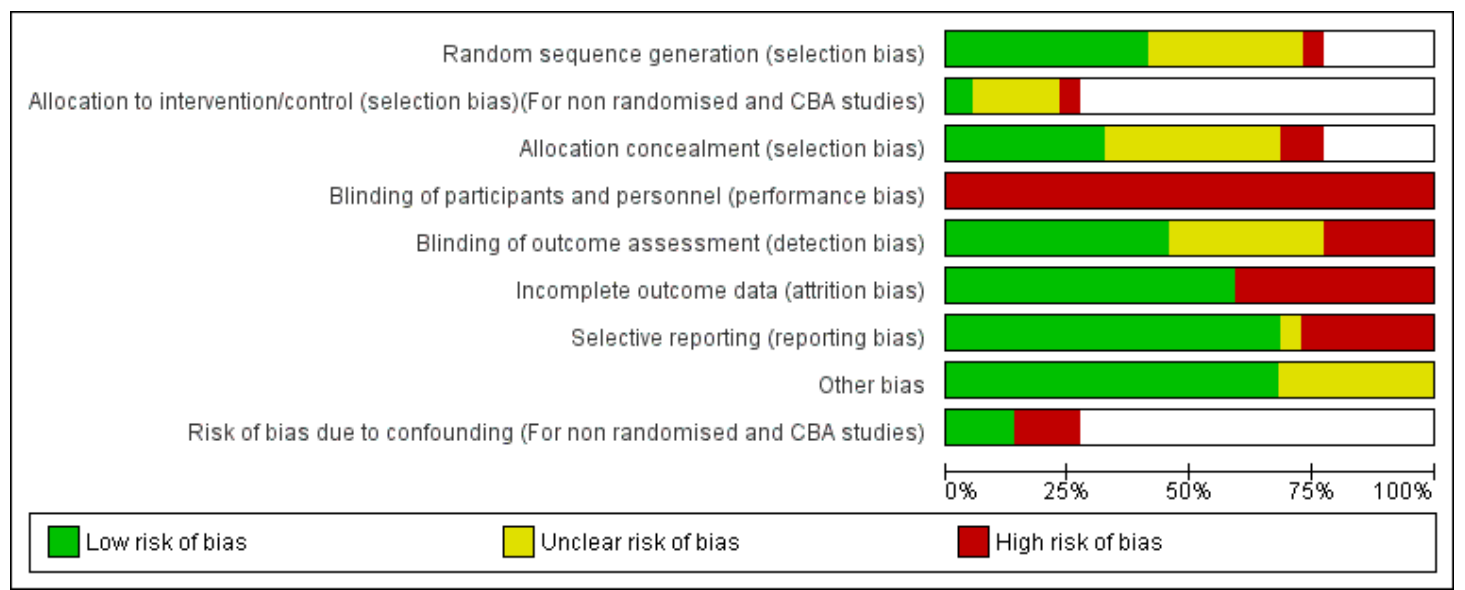

\section{Effects of interventions}

See: Summary of findings for the main comparison Parenting interventions compared to usual care for the prevention of unintentional injuries in childhood

\section{Medically attended or self-reported injury: RCTs}

Eleven RCTs reported medically attended or self-reported injury. One did not provide outcome by treatment group (Koniak-Griffin 2003) and thus results from ten RCTs were used in a meta-analysis. The findings from this (Analysis 1.1) show that the intervention arm families had a statistically significant lower risk of injury than control arm families (RR $0.83,95 \%$ CI 0.73 to 0.94 ; $\chi^{2}=9.23,9 \mathrm{df}, \mathrm{P}=0.42 ; \mathrm{I}^{2}=2 \%$ ). There did not appear to be any evidence of publication bias amongst the ten RCTs in the primary analysis (Egger's test regression coefficient $=-0.65(\mathrm{SE}$
0.49), $\mathrm{P}=0.22$ ) (Figure 4). The study reported by Duggan 2004 which measured maternal reports of medically attended injuries and medical records of hospitalisations for trauma found $1.5 \%$ of the 342 children in the intervention group hospitalised for trauma in the first three years of life compared to $1.7 \%$ of the 231 children in the control group (statistical significance not reported). One paper described two studies evaluating the same paediatric clinic based multi-faceted intervention (Minkovitz 2003 (a);Minkovitz 2003 (b)) using an RCT and a CBA. The randomised sites showed no statistically significant difference in emergency department use for injuries (OR $0.94,95 \%$ CI 0.65 to $1.34, \mathrm{P}=0.09$ ). While Koniak-Griffin 2003 reported number of visits to the ED by treatment group, the authors state that most of these visits were for illnesses and that while only 8 children were treated for injuries and accidents, this was not reported by treatment group. 
Figure 4. Funnel plot of comparison: I Intervention versus Control ( $\mathrm{n} / \mathrm{N}$ in clustered studies adjusted for clustering), outcome: I.I Medically attended or self-reported injuries - RCTs only.

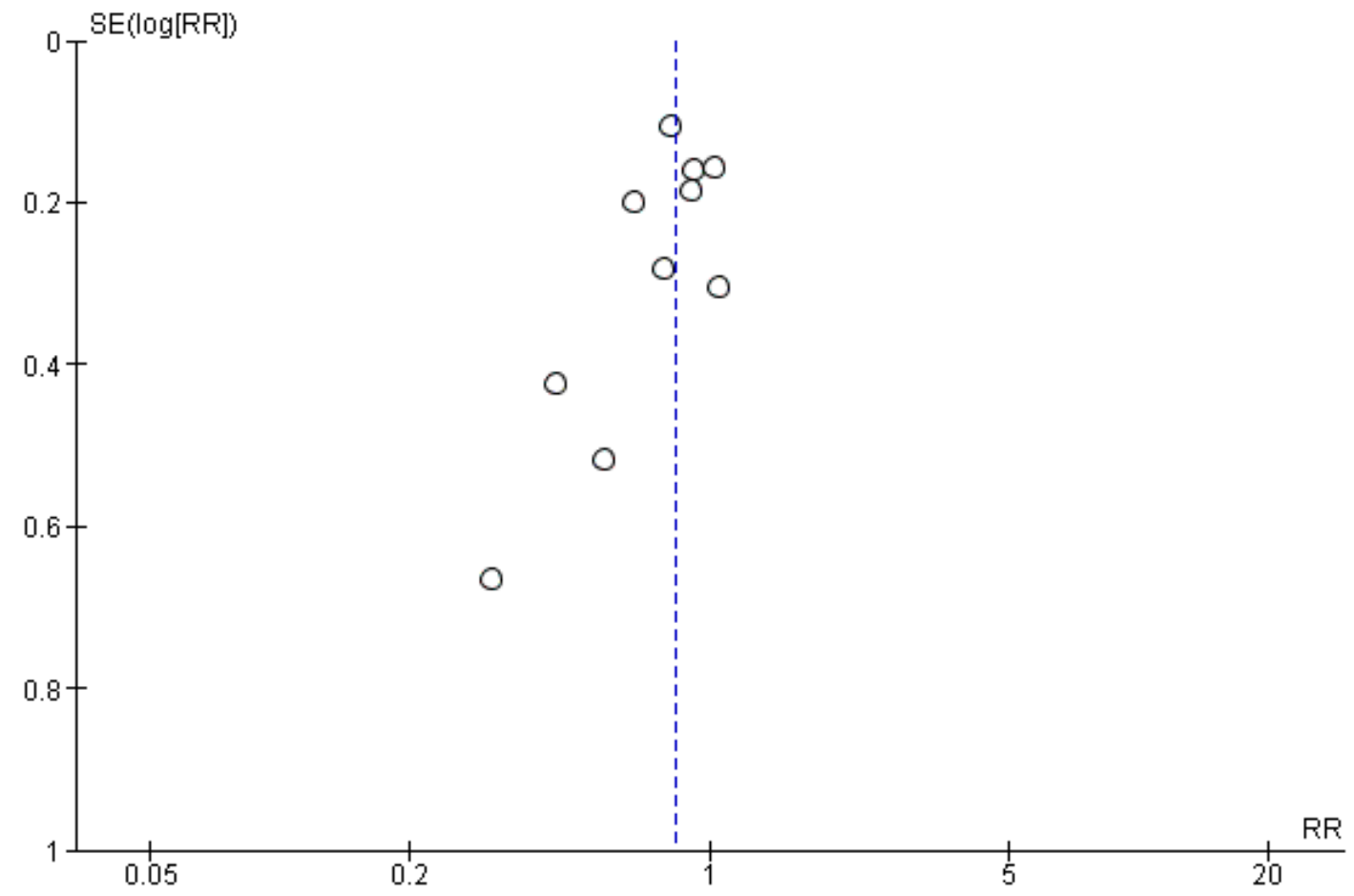

One study (Johnson 2000) reported medically attended injury at seven years follow-up from the Community Mothers trial by Johnson 1993. They reported that 10 children of 38 in the intervention group and 17 of 38 children from the control had had an accident requiring a visit to the hospital (RR 0.59, 95\% CI 0.31 to $1.11, \mathrm{P}=0.09)$. Unfortunately two thirds of participants had been lost to follow-up by seven years, but a sensitivity analysis was undertaken including the longer term but not shorter term results, as these were encompassed in the longer term results. The findings were robust to the use of the longer term results (RR 0.83 , $95 \%$ CI 0.74 to $0.94, \mathrm{P}=0.52$ ).

Sensitivity analyses were undertaken firstly using each of the injury outcomes reported by Armstrong 2000. The findings were robust to the varying definitions of injury (burns RR 0.85, 95\% CI 0.75 to 0.96 ; scratches RR $0.85,95 \%$ CI 0.75 to 0.96 ; unspecified injury RR $0.84,95 \%$ CI 0.74 to 0.95$)$. Findings were also robust (RR $0.85,95 \%$ CI 0.75 to 0.97 ) to excluding one study where the extent to which the intervention was based on a protocol, manual or curriculum was unclear (Fergusson 2005).

Finally sensitivity analyses were undertaken for the primary analysis including only RCTs at low risk of various sources of bias. The findings were robust to including only those studies at low risk of detection bias in terms of blinded outcome assessment (RR 0.83,
95\% CI 0.71 to 0.97) (Kitzman 1997; Duggan 1999; Armstrong 2000; Caldera 2007) and attrition bias in terms of follow up of fewer than $80 \%$ of participants in each arm (RR 0.80, 95\% CI 0.70 to 0.93) (Gutelius 1977; IHDP 1990; Johnson 1993; Kitzman 1997; Duggan 1999; Armstrong 2000; Fergusson 2005; Caldera 2007). When analyses were restricted to studies at low risk of selection bias in terms of inadequate allocation concealment (RR 0.83 , 95\% CI 0.67 to 1.04) (Johnson 1993; Kitzman 1997; Duggan 1999; Armstrong 2000; Minkovitz 2003 (a)) the relative risk was similar but the $95 \%$ CI were wider and the effect size was no longer statistically significant, possibly due to the small number of studies included in this sub group analysis. Overall, using GRADE, the quality of the evidence was rated as moderate (Summary of findings for the main comparison).

\section{Medically attended or self-reported injury: non RCTs}

Six non-RCTs reported medically attended or self-reported injury. Two of the non RCTS used clustered allocation (Minkovitz 2003 (b); Culp 2007) and reported numerators and denominators for emergency department use for injury-related causes allowing us to adjust for clustering using an intra-class correlation coefficient 
of 0.017 (Kendrick 1999) and these were rounded to the nearest integer. Two studies evaluating the same paediatric clinic based multi-faceted intervention (Minkovitz 2003 (a); Minkovitz 2003 (b)) using an RCT and a CBA, found a statistically significant reduction in emergency department use for injuries only in the CBA study sites (OR $0.67,95 \%$ CI 0.49 to $0.90, \mathrm{P}=0.02$ ). After adjusting for clustering there were 32 visits to $\mathrm{ED}$ for injury related causes for 368 children in the intervention arm and 40 reported for 342 children in the control arm (Minkovitz 2003 (b)). Larson 1980 found that 64 children in the intervention arm suffered 42 accidents compared to 32 accidents suffered by 41 children in the control arm, a statistically significant difference $(\mathrm{P}<0.1)$. A second study also found statistically significant fewer intervention arm mothers than mothers in the control arm reporting injuries to their children in the preceding 12 months after adjusting for confounding factors and for clustering (OR $0.54,95 \%$ CI 0.33 to $0.88, \mathrm{P}=0.022$ ) (Emond 2002). In contrast, Hardy 1989 reported $8(6 \%)$ observations of sustained closed head trauma for 131 children in the intervention arm and $15(11 \%)$ for 132 children in the control arm. This difference was not statistically significant. Similarly Culp 2007 did not find a statistically significant difference between the intervention and control arms. After adjusting for clustering 7 visits were made to the emergency department for 103 children in the intervention arm and 11 visits for 86 children in the control arm (statistical significance not reported).

\section{Home safety outcomes}

Studies reported home safety practices and hazards using a variety of methods and scales.

\section{Home observation for measurement of the environment (HOME) scores}

Ten studies reported total HOME or subscale scores (Table 2). One study (Duggan 1999) only reported results from subscales that were irrelevant to this review. Authors most often reported HOME scores at 12 months (six of ten studies) but frequently reported insufficient detail for the study data to be included in a metaanalysis. Data on total HOME scores at 12 months from three RCTs (Armstrong 2000; Koniak-Griffin 2003; Barlow 2007) were included in a meta-analysis. Data from one RCT (Koniak-Griffin 2003) was received in a personal communication. Results from the meta-analysis show that there was no statistically significant difference in total HOME scores between intervention and control arm families (mean difference $0.57,95 \%$ CI -0.59 to $1.72 ; \chi^{2}=0.41$, $2 \mathrm{df}, \mathrm{P}=0.82 ; \mathrm{I}^{2}=0 \%$ ) (a higher HOME score represents a more enriched home environment for the child.) Armstrong 2000 also reported organisation of the home environment subscale scores and found a statistically significant difference favouring the intervention arm (mean score intervention arm 5.70 (SD 0.77) versus mean score control arm 5.11 (SD 1.16), $\mathrm{P}<0.05$ ). Barlow 2008 reported that no statistically significant differences were found between the home visiting and control groups on the HOME Inventory scale at 36 months postnatally (mean score intervention arm $=24.76$ (no SD reported), mean score control arm at 36 months 23.45 (no SD reported), $\mathrm{P}=0.98$ ).

Of the six studies not included in the meta-analysis which reported total HOME scores or organisation of the environment subscale scores, two found statistically significant differences favouring intervention arm families (Larson 1980; Kitzman 1997). Kitzman 1997 found a statistically significant effect of the intervention on the overall HOME score at 24 months (total HOME score intervention arm 32.3 versus control arm 30.9 (SDs not reported), mean difference $-1.3,95 \% \mathrm{CI}-2.2$ to $-0.4, \mathrm{P}=0.003)$. Larson 1980 found that mothers in intervention group A (ante-natal and post-natal programme) had statistically significant higher overall HOME scores than those in group B (post-natal programme only) or the control arm at three of the four assessment points (mean group $\mathrm{A}$ at six weeks, six months, 12 months and 18 months; 29.3 ; 35.2; 40.1 ; 41.2 versus means group $B ; 25.8$; 33.7; 37.8; 38.6; versus means control arm; 26.7; 33.2; 37.8; 39.0; (no SD reported), P values $<0.001 ;<0.005 ;<0.017 ;<0.041)$.

Four studies found no statistically significant difference between treatment arms, with one study finding statistically significant differences only amongst distressed mothers (Kemp 2011). Caldera 2007 found no statistically significant difference in total HOME scores at 24 months follow up (mean score intervention arm 36.7 versus 35.9 control arm, ( $\mathrm{SD}$ not reported), $\mathrm{P}=0.10$ ). Fewer intervention than control families had extremely poor total HOME scores (i.e. less than or equal to 33$)(20 \%$ versus $31 \%, \mathrm{P}<0.001)$. Group scores did not differ statistically significantly on any HOME subscale. Kemp 2011 reported organisation of the home environment subscale scores and found no statistically significant difference between groups (mean score intervention arm 4.92 (SE 0.08 ), mean score control arm 4.84 (SE 0.08), mean difference $0.09,95 \%$ CI -0.13 to 0.30$) \mathrm{P}=0.43$ ). Kemp 2011 also reports scores for mothers with more than one risk factor (mean score intervention arm 4.96 (SE 0.10), mean score control arm 4.68 (SE 0.11 ), mean difference 0.27 ( $95 \% \mathrm{CI}-0.03$ to 0.57$), \mathrm{P}=0.07$ ) and for distressed mothers (mean score intervention arm $5.00(\mathrm{SE}=$ $0.10)$, mean score control arm $4.60(\mathrm{SE}=0.10)$, mean difference 0.40 (95\% CI 0.11 to 0.69 ), $\mathrm{P}=0.01$ ). It is not clear whether reported results were measured at 12 or 24 months. Olds 1994 reported no statistically significant differences in total HOME scores at both 34 (mean score intervention arm 39.08, mean score control arm 39.03 (mean difference $-0.05,95 \%$ CI -1.92 to 1.84 ) and 46 months (mean score intervention arm 39.66, mean score control arm 39.67 (no SD reported), mean difference $=0.01,95 \%$ CI -1.66 to 1.67). St Pierre 1999 present total HOME scores measured at four years and found no statistically significant difference between groups (mean score intervention arm mean 32.55, $\mathrm{SD}=$ 9.46, mean score control arm 33.03, $\mathrm{SD}=9.45$, P value reported only as "non significant"). 


\section{Safety practices}

Seven studies reported specific safety practices or use of items of safety equipment, with 5 finding effects favouring intervention arm families.

Olds 1994 found no effect of the intervention on the extent to which mothers reported that they kept poisonous substances out of reach of their children or used child restraints in cars. Feldman 1992 measured sleep safety but only reports findings for all childcare skills combined. The intervention arm had a statistically significant higher score for all child-care skills at follow up than the control arm (intervention arm mean $88.1 \%$ skills correct (no SD reported) versus control arm mean $60.6 \%$ skills correct (no SD reported), $\mathrm{P}<0.001$ ).Emond 2002 reported statistically significant more mothers in the intervention arm used electric socket covers (OR adjusted for confounders and clustering 1.92, 95\% CI 1.16 to $3.17, \mathrm{P}=0.019$ ) and safety gates (data not reported) than control arm mothers.

Johnston 2004 found no statistically significant difference in the use of safe-sleep practices a 3 months post partum between treatment groups (intervention arm $=80.1 \%$ versus control $\mathrm{arm}=$ $80.3 \%$, adjusted RR 1.02, 95\% CI 0.98 to 1.05 ). Johnston 2006 reporting on the same participants as Johnston 2004 at 30 months post partum found that intervention arm families were statistically significantly more likely to use stair gates than control arm families ( $\mathrm{I}=33.2 \%$ vs $\mathrm{C}=30.2 \%$, RR 1.19 ( 1.15 to 1.23 ), $\mathrm{P}<0.05$ ) and to have the local poison control centre number accessible (I= $95.8 \%$ vs. $\mathrm{C}=90.4 \%$, RR 1.08 (1.03 to 1.12$), \mathrm{P}<0.05)$ but were statistically significantly less likely to use safety latches on cabinets ( $\mathrm{I}=66.8 \%$ vs. $\mathrm{C}=77.9 \%$, RR 0.88 (0.83 to 0.93 ), $\mathrm{P}<0.05$ ). There was no statistically significant difference between groups for use of covers on electrical outlets (I=92.9\% vs $\mathrm{C}=92.3 \%$, RR1.00 (0.98 to 1.03$)$.

Minkovitz 2003 (a) reporting results from the RCT found no statistically significant difference in the proportion of families who lowered the temperature on water heaters (intervention arm = $64.4 \%$ versus control arm $=60.4 \%, P=0.11$ ) or used safety latches on cabinets (intervention arm $=63.3 \%$ versus control arm $=61.8 \%, \mathrm{P}=0.34)$. However there was a statistically significant difference in the proportion of families who used covers on electric sockets (intervention arm $=91.9 \%$ versus control arm $88.8 \%$, $\mathrm{P}=0.04$ ). Results from the CBA (Minkovitz 2003 (b)) found no statistically significant difference in the proportion of families who lowered the temperature on water heaters (intervention arm $=56.8 \%$ versus control arm $=56.3 \%, P=0.82$ ), used covers on electric sockets (intervention arm $=90.5 \%$ versus control arm $89.5 \%, \mathrm{P}=0.46$ ), used safety latches on cabinets (intervention arm $=63.5 \%$ versus control arm $=62.5 \%, P=0.62$ ). Culp 2007 reported that intervention arm families were more likely to have hot water adjusted to a safe temperature and electrical cords beyond a child's reach (figures and P values not reported).

\section{Home hazards}

Two studies reported measures of home hazards.

Olds 1994 reported statistically significant fewer observed hazards in the home at both 34 (mean intervention arm 0.22 versus control arm 0.38 (no SD reported), $\mathrm{P}=0.04$ ) and 46 months (mean intervention arm 0.21 versus control arm 0.46 (no SD reported), $\mathrm{P}=0.003$ ) amongst intervention arm families than control arm families.

Llewellyn 2003 compared the Home Learning Programme with home visits without parental education, with lesson only booklets without any face-face education and with usual care. They found that parents in the Home Learning Programme group identified statistically significant more dangers within the home (mean 76.25 (SD 10.64)) than those who had received home visits without parental education (mean 54.82 (SD 15.78)) or those who had received only usual care (two groups: mean first control group 55.70 (SD 8.06), mean second control group 57.33 (SD 19.22), $\mathrm{P}<0.001$ ); suggesting that the beneficial effects were attributable to the parenting intervention rather than the home visit, but care must be taken in interpreting this finding as it relates only to one study. Parents in the Home Learning Programme group also identified statistically significantly more dangers within the home (mean 76.27 (SD 13.67)) than those in the lesson booklet only group (mean 62.0 (SD 12.53), $\mathrm{P}<0.001$ ), suggesting a greater effect of face to face education than providing written information. The Home Learning Programme group also identified a statistically significant greater number of precautions to reduce the risk of injury (mean 78.85 (SD 17.24)) than those who had received home visits without parental education (mean 48.91 (SD 15.36)), or those who had received usual care (two groups, mean first control group 47.10 (SD 13.76), mean second control group 45.33 (SD 13.87), $\mathrm{P}<0.001$ ); again suggesting a beneficial effect of parental education above that achieved from the home visit. Parents in the Home Learning Programme group identified statistically significantly more precautions to reduce the risk of injury (mean 85.27 (SD 21.12)) than those in the lesson booklet only group (mean 54.29 (SD 17.06), $\mathrm{P}<0.001$ ), again suggesting greater effects of face-face education than providing written information. Finally, parents in the Home Learning Programme group implemented a statistically significantly greater number of precautions to reduce the risk of injury (mean 88.09 (SD 34.92)) than those in the lesson booklet only group (mean 57.50 (SD 11.48), $\mathrm{P}<0.001$ ); again suggesting face-to-face educational visits had a greater effect than providing written information.

\section{Composite home safety measures}

One study (Johnston 2004) reported a composite home safety measure, the Home Safety Index developed for the study, comprising the sum of binary responses to six items (maximum possible score 7) on car seat use, safe storage of firearms, functioning smoke detectors, scald prevention activities and safe infant sleep practices. 
At 3 months post-partum intervention arm families had a statistically significantly higher mean score (reflecting safer practices) than control arm families (intervention arm mean $=6.28$ ( $\mathrm{SD}=$ $0.89)$ vs control arm mean $=6.10(\mathrm{SD}=1.11)$, difference between the means $0.10,95 \%$ CI 0.02 to 0.17 ). This difference was mainly due to differences in gun storage practices.

Johnston 2006 reporting on the same families as Johnston 2004 but at 30 months post partum used the same tool minus the sleep safety practices. Intervention arm families were statistically significantly more likely to report safe practices for all items than control arm families (intervention arm $86.2 \%$ vs control arm $72.1 \%$, RR 1.19 (1.09 to 1.28$), \mathrm{P}<0.05)$.

Culp 2007 assessed home safety using the Massachusetts Home Safety Questionnaire. This scale assessed both safety practices and use of safety equipment. At 12 months, families in the intervention group had statistically significantly safer homes $(\mathrm{M}=38.1, \mathrm{SD}=$ 2.4) than the control group families $(M=36.9$, SD 2.6, $t(261)=$ 3.9, $\mathrm{P}=0.0001$ ).

\section{DISCUSSION}

\section{Principal findings}

We have found that parenting interventions, most commonly provided on a one to one basis in the home as part of multi-faceted interventions to improve a range of child (and often maternal health) outcomes during the first two years of a child's life, are effective in reducing self-reported or medically attended injury amongst young children. This finding was consistent across studies with little evidence of statistical heterogeneity between effect sizes. This finding was also robust to most aspects of study quality and study design. All but one of the studies contributing to this analysis evaluated multi-faceted home visiting programmes. However, one study in which the intervention was primarily provided in paediatric primary care, found a similar effect size to that from the home visiting programmes but this was confined to a non-randomised part of the study. Only two studies reported effects of parenting interventions comprising solely educational interventions; neither of which measured injury outcomes or was included in the metaanalyses.

in terms of home safety, parenting interventions appeared to have a greater effect on home safety practices and reduction of hazards than on HOME scores. Meta-analysis of HOME scores found no statistically significant difference between treatment arms. Only 3 studies were included in this meta-analysis. Three studies not included in the meta-analysis found statistically significant differences in total HOME scores or organisation of the environment subscale scores. Three studies reporting home safety using alternative composite scores found intervention arm families had statistically significantly safer homes. Five of the seven studies assessing home safety practices and use of safety equipment found statistically significant effects favouring intervention arm families. The two studies reporting home hazards found fewer hazards in the homes of intervention arm families. There is therefore fairly consistent evidence that parenting interventions can have a positive effect on both home safety and childhood injury rates. Only one study used a control group that received home visits but without also providing a parenting intervention (Llewellyn 2003), so allowing the effect of the intervention to be assessed above any effect of the home visit per se. Their findings suggested the beneficial effects were attributable to the parenting intervention rather than the home visit, but care must be taken in interpreting this finding as it relates only to one study

\section{Strengths and weaknesses of this systematic review}

Our search strategy included searching a large number of bibliographic databases, grey literature and handsearching some conference abstracts and journals. However, our search terms included injury and home safety outcome terms and as these may have been secondary outcomes in some studies, this may have led to some studies being missed by our searches. However, we attempted to contact the authors of all studies excluded on the basis of outcomes to ascertain if they had measured any outcomes relevant for our review. Of the seven papers excluded on the basis of lack of relevant outcomes, the authors of two confirmed that they did not assess unintentional injury, two authors were untraceable and three did not respond. There did not appear to be evidence of publication bias although the number of studies included in this assessment was fairly small (10), hence the funnel plot and Egger's test should be interpreted with caution. The analysis adjusted for cluster allocated studies and sensitivity analyses were undertaken testing assumptions regarding the potential for bias, uncertainty as to the extent to which the intervention was based on a protocol, manual or curriculum, follow-up period and injury type. The findings were robust to these assumptions.

The parenting interventions included in our review were complex interventions and only a minority of studies were explicit about the theoretical basis of the intervention or hypothesised about why it may have resulted in a reduction in childhood injuries (Olds 1986; Kitzman 1997; Minkovitz 2003 (a); Minkovitz 2003 (b); Johnston 2004). Meta-analyses for home safety outcomes other than for HOME scores was not possible due to the variety of tools and subscales used. The meta-analysis of HOME scores did not find a statistically significant difference between treatment arms, but only included 3 studies and hence will have had limited power. In addition, the meta-analysis was restricted to the total HOME score containing 6 domains, only one of which measured home safety.

The generalisability of the findings are limited by the study populations, which mainly comprised families considered to be 'at risk' of adverse child health outcomes. In addition, all included 
studies came from high income countries, so the findings may not be generalisable to low or middle income countries. All studies provided the intervention to individual parents, and whilst several also included some parents groups, none of the studies delivered the intervention primarily to groups of parents, hence findings may not be generalisable to group-based parenting interventions. Similarly most studies provided the intervention mainly within the home, so the findings may not be generalisable to parenting interventions provided outside the home.

\section{Strengths and weaknesses of included studies}

All reviews are dependent on the quality of reporting in the included studies and the availability and willingness of study authors to respond to requests for information. Unsurprisingly, the more recently published studies, especially RCTs, tended to be reported more comprehensively. The majority of studies described the content of the intervention in sufficient detail and described and reported injury outcomes enabling data to be extracted for meta-analysis. Three cluster allocated studies reported findings adjusted for clustering (Emond 2002; Minkovitz 2003 (b); Johnston 2004). Most studies used parental reports of injuries, which may be subject to biased reporting, particularly as blinding participants to treatment arm allocation is not possible with interventions such as these. However, there did not appear to be a consistent relationship between self-reported injury or that verified by medical records and effect size. Safety outcomes were reported less consistently, with a minority of studies reporting whether a statistically significant difference was found, but not reporting effect sizes for some safety outcomes (Olds 1986; Feldman 1992; Emond 2002; Culp 2007). Some studies reported overall Home Observation of the Environment scores but not the subscale most relevant to child safety (Larson 1980; Olds 1986; Kitzman 1997; St Pierre 1999; Armstrong 2000; Koniak-Griffin 2003; Barlow 2007; Caldera 2007), or an overall score for the Massachusetts Home Safety Questionnaire but subscale scores for safety practices and use of safety equipment (Culp 2007) or scores for all child care skills combined but not separate sleep safety scores (Feldman 1992). It is possible that improvements in the safety subscales were not reflected in improvements in overall scores (Armstrong 2000). The quality of studies was variable, with either half or more of the RCTs included in the meta-analysis being susceptible to bias in terms of allocation concealment and/or outcome assessment. However, despite this, sensitivity analyses demonstrated little impact of excluding studies without blinded outcome assessment on the results. Excluding studies without adequate allocation concealment resulted in a similar effect size but the effect was no longer statistically significant, possibly due to a lack of power. Only two studies included in the meta analysis reported high attrition rates.
Although there are no existing systematic reviews examining the effect of parenting interventions on child injury, our findings are consistent with those of two previous meta-analyses examining the effect of home visiting programmes on child injury (Roberts 1997; Elkan 2000).

\section{Potential explanations for the findings}

The authors of included studies suggest that a reduction in injuries may have occurred via a range of mechanisms including increasing the ability of parents to manage minor injuries without medical help (Kitzman 1997), improvements in the quality of child care provided (Olds 1986; Kitzman 1997), including parental 'guidance' (Olds 1986), home safety (Olds 1986; Culp 2007) and greater belief that children must be protected in order to 'succeed in school, work and mainstream society' (Olds 1986). Our review suggests that parenting interventions are likely to improve home safety, but there are also other plausible explanations for why parenting interventions may reduce childhood injuries. All studies included in the primary meta-analysis were aimed at improving a range of child (and often maternal) health outcomes. Six of these studies reported statistically significant improvements in child behaviour (Gutelius 1977; Olds 1986; IHDP 1990; Fergusson 2005; Johnston 2006; Caldera 2007), three reported statistically significant less punitive discipline practices amongst intervention group parents (Kitzman 1997; Duggan 1999; Fergusson 2005); five reported statistically significantly increased or improved mother-child interaction (Gutelius 1977; Olds 1986; Johnson 1993; Armstrong 2000; Johnston 2004) and two reported statistically significant improvements in maternal psychological wellbeing (Johnson 1993; Johnston 2004). It is therefore possible that the reduction in childhood injuries may result from improvements in child behaviour, more effective supervision or discipline practices or greater or more positive interactions between mother and child; all of which may be associated with improved maternal psychological wellbeing. A recent large systematic review of home safety education and the provision of safety equipment found strong evidence that these increased home safety practices and behaviours and some evidence that they reduced childhood injury (Kendrick 2012). None of the studies we included in our review specifically provided or fitted home safety equipment and it is plausible that combining parenting interventions with the provision and fitting of safety equipment may further enhance their effect on childhood injury.Understanding how parenting interventions work and which components of often complex interventions are necessary or sufficient to reduce childhood injury, is important for designing effective and efficient services for children and parents.

\section{Findings in relation to previous research}

\section{A U THORS' CONCLUSIONS}

Parenting interventions for the prevention of unintentional injuries in childhood (Review) 


\section{Implications for practice}

Parenting interventions, most commonly provided within the home as part of a multi-faceted intervention to improve a range of child (and often maternal health) outcomes are effective in reducing self-reported or medically attended unintentional injury. There is also fairly consistent evidence that they improve home safety. The evidence relates mainly to interventions provided to families 'at risk' of adverse child health outcomes including those 'at risk' of child abuse and neglect. Health and social care providers should provide home visiting programmes to such families as part of their injury prevention, and wider child and maternal health strategies. Such provision is also likely to have a range of other beneficial effects for maternal and child health.

\section{Implications for research}

There are a series of research questions which remain to be answered. Firstly whether parenting interventions delivered outside the home have positive effects on childhood injury; whether parenting educational interventions, as opposed to multi-faceted interventions, delivered within or outside the home and aimed at improving a range of parenting practices are effective in reducing childhood injury; whether group-based parenting interventions are effective in reducing childhood injury; whether providing home safety education and safety equipment provision further increase the effectiveness of parenting interventions in reducing child injury, and finally whether parenting interventions are effective in reducing child injury when delivered to families not considered to be 'at risk' of adverse child health outcomes.

\section{ACKNOWLEDGEMENTS}

We would like to thank A. Culp for providing us with unpublished data and J. Barlow for providing us with a copy of an unpublished report.

\section{R E F E R E N C E S}

\section{References to studies included in this review}

Armstrong 2000 \{published data only\}

Armstrong KL, Fraser JA, Dadds MR, Morris J. Promoting

a secure attachment, maternal mood and child health in

a vulnerable population: a randomized controlled trial.

Journal of Paediatrics and Child Health 2000;36:555-62.

Barlow 2007 \{published data only\}

Barlow J, Davis H, McIntosch E, Jarrett P, Mockford C, Stewart-Brown S. Role of home visiting in improving parenting and health in families at risk of abuse and neglect: results of a multicentre randomised controlled trial and economic evaluation. Archives of Disease in Childhood 2007; 92(3):229-33.

Caldera 2007 \{published data only\}

Caldera D, Burrell L, Rodriguez K, Crowne SS, Rodhe C, Duggan A. Impact of a statewide home visiting program on parenting and on child health and development. Child Abuse \& Neglect 2007;31:829-852.

Culp 2007 \{unpublished data only\}

Culp AM, Culp R, Anderson J, Carter S. Health and safety intervention with first-time mothers. Health Education Research 2007;22(2):285-94.

Duggan 1999 \{published data only\} Duggan AK, McFarlane EC, Windham AM, Rhode CA, Salkever DS, Fuddy L, et al.Evaluation of Hawaii's Healthy Start Program. Future of Children 1999;9(1):66-90.

Emond 2002 \{published data only\} Emond A, Pollock J, Deave T, Bonnell S, Peters TJ, Harvey I. An evaluation of the First Parent Health Visitor Scheme. Archives of Disease in Childhood 2002;86:150-7.
Feldman 1992 \{published data only\} Feldman MA, Case L, Sparks B. Effectiveness of a childcare training program for parents at-risk for child neglect. Canadian Journal of Behavioural Science 1992;24(1):14-28.

Fergusson 2005 \{published data only\} Fergusson DM, Grant H, Horwood LJ, Ridder EM. Randomized trial of the early start program of home visitation. Pediatrics 2005;116:803-9.

Gutelius 1977 \{published data only\} Gutelius MF, Kirsch AD, McDonald S, Riddick Brooks M, McErlan T. Controlled study of child health supervision: behaviour results. Pediatrics 1977;60(3):294-304.

Hardy 1989 \{published data only\}

Hardy JB, Streett R. Family support and parenting education in the home: an effective extension of clinicbased preventive health care services for poor children. Journal of Pediatrics 1989;115(6):927-31.

\section{IHDP 1990 \{published data only\}}

The Infant Health \& Development Program. Enhancing the outcomes of low-birth-weight, premature infants. A multisite, randomized trial. Journal of the American Medical Association 1990;263(22):3035-42.

Johnson 1993 \{published data only\}

Johnson Z, Howell F, Molloy B. Community mothers' programme: randomised controlled trial of non-professional intervention in parenting. British Medical Journal 1993;306 (6980):1449-52.

Johnston 2004 \{published data only\} Johnston B, Huebner CE, Tyll LT, Barlow WE, Thompson RS. Expanding developmental and behavioural services for newborns in primary care: effects on parental well being, 
practice and satisfaction. American Journal of Preventive Medicine 2004;26(4):356-66.

Kemp 2011 \{published data only\}

Kemp L, Harris E, McMahon C, Matthey S, Vimpani G, Anderson T, et al.Child and family outcomes of a long-term nurse home visitation programme: a randomised controlled trial. Archives of Diseases in Childhood 2011;96:533-540.

Kitzman 1997 \{published data only\}

Kitzman H, Olds DL, Henderson CR, Hanks C, Cole R, Tatelbaum R, et al.Effect of prenatal and infancy home visitation by nurses on pregnancy outcomes, childhood injuries, and repeated childbearing. A randomised controlled trial. Journal of the American Medical Association 1997;278(8):644-52.

Koniak-Griffin 2003 \{published data only\}

Koniak-Griffin D, Verzemnieks IL, Anderson NLR, Brecht M-L, Lesser J, Kim S, et al.Nurse visitation for adolescent mothers. Nursing Research 2003;52(2):127-136.

Larson 1980 \{published data only\}

Larson CP. Efficacy of prenatal and postpartum home visits on child health and development. Pediatrics 1980;66(2): 191-7.

Llewellyn 2003 \{published data only\}

Llewellyn G, McConnell D, Honey A, Mayes R, Russo D. Promoting health and home safety for children of parents with intellectual disability: a randomized controlled trial. Research in Developmental Disabilities 2003;24(6):405-31.

Minkovitz 2003 (a) \{published data only\} Minkovitz C, Hughart N, Strobino D, Scharfstein D, Grason $\mathrm{H}$, Hou W, et al.A practice-based intervention to enhance quality of care in the first 3 years of life. Journal of the American Medical Association 2003;293(23):3081-91.

Minkovitz 2003 (b) \{published data only\} Minkovitz C, Hughart N, Strobino D, Scharfstein D, Grason $\mathrm{H}$, Hou W, et al.A practice-based intervention to enhance quality of care in the first 3 years of life. Journal of the American Medical Association 2003;293(23):3081-91.

Olds 1986 \{published data only\}

Olds DL, Henderson CR, Chamberlain R Jr, Tatelbaum R. Preventing child abuse and neglect: a randomized trial of nurse home visitation. Pediatrics 1986;78(1):65-78.

St Pierre 1999 \{published data only\}

St Pierre R, Layzer JI. Using home visits for multiple purposes: the Comprehensive Child Development Program. The Future of Children 1999;1:134-151.

\section{References to studies excluded from this review}

Akinbami 2001 \{published data only\}

Akinbami LJ, Cheng TL, Kornfeld D. A review of teen-tot programs: comprehensive clinical care for young parents and their children. Adolescence 2001;36(142):381-93.

Babul 2007 \{published data only\}

Babul S, Olsen L, Janseen P, McIntee P, Raina P. A randomized trial to access the effectiveness of an infant home safety programme. Interntionational Journal of Injury Control and Safety Promotion 2007;14(2):109-17.

Baron-Epel 2006 \{published data only\}

Baron-Epel O, Hemmo-Lotem M, Mike-Doron R, EndyFindling L, Balin L. Injury prevention counselling of families with children hospitalized due to injuries: The "Personalized Injury Prevention" Program. 8th World conference on Injury Prevention and Safety Promotion. South Africa, 2006

Beirens 2006 \{published data only\} Beirens T. Effectiveness of standardized safety information provided through Dutch well-child clinics to parents of 1118 months old toddlers. World Safety Conference. 2006.

Bond 2006 \{published data only\} Bond LA, Burns CE. Mothers' beliefs about knowledge, child development and parenting strategies: expanding the goals of parenting programs. The Journal of Primary Prevention 2006;27(6):555-571.

Conroy 1994 \{published data only\}

Conroy M. Increasing agreement on safe parenting in twoparent families at risk for physical child abuse (Dissertation). University of San Francisco 1994.

Culp 1998 \{published data only\}

Culp AM, Culp RE, Blankmeyer M, Passmark L. Parent education home visitation program: adolescent and non adolescent mother comparison after 6 months of intervention. Infant Mental Health Journal 1998;19(2): 111-23.

Cupples 2011 \{published data only\} Cupples ME, Stewart MC, Percy A, Hepper P, Murphy C, Halliday HL. A RCT of peer-mentoring for first-time mothers in socially disadvantaged areas (The MOMENT study). Archives of Diseases in Childhood 2011;96:252-8.

Dawson 1989 \{published data only\} Dawson P, Van Doorninck WJ, Robinson JL. Effects of home based, informal social support on child health. Developmental and Behavioral Pediatrics 1989;10(2):63-7.

Donnellan 1981 \{published data only\} Donnellan GJ, others. Prevention Service Programs for infants of mentally-ill mothers: Progress report. Annual Meeting of the.American Psychological Association 89th. 1981; Vol. Los Angeles, CA. August 24-28.

Ertem 2006 \{published data only\} Ertem IO, Atay G, Bingoler BE, Dogan DG, Bayhan A, Sarica D. Promoting child development at sick-child visits: a controlled trial. Pediatrics 2006;118(1):124-131.

Feldman 2004 \{published data only\} Feldman MA. Self-directed learning of child-care skills by parents with intellectual disabilities. Infants and Young Children 2004;17(1):17-31.

Fitzpatrick 1997 \{published data only\} Fitzpatrick P, Molloy B, Johnson Z. Community mothers' programme: extension to the travelling community in Ireland. Journal of Epidemiology \& Community Health 1997; 51(3):299-303. 
Gershater-Molko 2002 \{published data only\}

Gershater Molko RM, Lutzker JR, Wesch D. Project

SafeCare: Improving Health, Safety, and Parenting Skills in Families Reported for, and At-Risk for Child Maltreatment. Journal of Family Violence 2003;18(6):377-86.

Gershater-Molko 2003 \{published data only\} Gershater-Molko RM. A comprehensive evaluation of project Safecare: Health, safety, bonding and recidivism in families reported for, and at risk for, child maltreatment, and finishing treatment (Dissertation). University of Kansas 2002.

Gray 1979 \{published data only\}

Gray JD, Cutler CA, Dean JG, Kempe CH. Prediction and prevention of child abuse and neglect. Journal of Social Issues 1979;35(2):127-39.

Guyer 2000 \{published data only\}

Guyer B, Hughart N, Strobino D, Jones A, Scharfstein D. Assessing the impact of pediatric-based developmental services on infants, families and clinicians: challenges to evaluating the Healthy Steps Program. Pediatrics 2000;105 (3):E33.

Hedges 2005 \{published data only\}

Hedges S, Simmes D, Martinez A, Linder C, Brown S. A home visitation program welcomes home first-time moms and their infants. Home Healthcare Nurse 2005;23(5): 286-9.

Hemmo-Lotom 2006 \{published data only\} Hemmo-Lotom, M. Parental knowledge, attitudes and practice concerning prevention of children's falls. 8th World conference on Injury Prevention and Safety Promotion. South Africa, 2006.

Huxley 1993 \{published data only\}

Huxley P, Warner R. Primary prevention of parenting dysfunction in high-risk cases. American Journal of Orthopsychiatry 1993;63(4):582-8.

Jackson 2009 \{published data only\} Jackson C, Dickinson DM. Developing parenting programs to prevent child health risk behaviours: a practice model. Health Education Research 2009;24(6):1029-1042.

Johnson 2009 \{published data only\}

Johnson S, Whitelaw A, Glazebrook C, Israel C, Turner R, White IR, et al.Randomized trial of a parenting intervention for very preterm infants: outcome at 2 years. The Journal of Pediatrics 2009;155(4):488-494.

\section{Jordaan 2006 \{published data only\}}

Jordaan E. The usefulness of a new instrument, developed to measure the prevention effect of the home visitation programme, focussing on unintentional home injuries in young children in a low income South African setting. 8th World conference on Injury Prevention and Safety Promotion. South Africa. 2006.

Jouriles 2010 \{published data only\} Jouriles EN, McDonald R, Rosenfiled D, Norwood WD, Spiller L, Stephens N, et al.Improving parenting in families referred for child maltreatment: a randomized controlled trial examining effects of project support. Journal of Family Psychology 2010;24(3):328-338.

Kluger 2000 \{published data only\} Kluger MP, Alexander G, Curtis PA. (Editors). What Works in Child Welfare. CWLA, USA., 2000.

Lealman 1983 \{published data only\} Lealman GT, Haigh D, Phillips JM, Stone J, Ord-Smith C. Prediction and prevention of child abuse - an empty hope. The Lancet 1983;1(8339):1423-4.

McAuley 2004 \{published data only\} McAuley C, Knapp M, Beecham J, McCurry N, Sleed M. Young families under stress. Outcomes and costs of home start support. York: Joseph Rowntree Foundation, 2004.

Odendall 2009 \{published data only\}

Odendall W. The impact of a home visitation programme on household hazards associated with unintentional childhood injuries: a randomised controlled trial. Accident Analysis and Prevention 2009;41(1):182-90.

Powell 2004 \{published data only\}

Powell C, Baker-Henningham H, Walker S, Gernay J, Grantham-McGregor S. Feasibility of integrating early stimulation into primary care for undernourished Jamaican children: cluster randomised controlled trial. British Medical Journal 2004;329(7457):89-93.

Quraishi 2005 \{published data only\} Quraishi AY, Mickalide AD, Cody BE. Follow the leader: a national study of safety role modelling among parents and children. Washington (DC): National SAFE KIDS Campaign; April 2005.

Sharma 2006 \{published data only\}

Sharma G. Educational intervention in changing knowledge of mothers of under five children in reducing injuries among Nepalese children. 8th World conference on Injury Prevention and Safety Promotion. South Africa. 2006.

Smith 1984 \{published data only\}

Smith JE, Rachman SJ. Non-accidental injury to childrenII. A controlled evaluation of a behavioural management programme. Behaviour Research and Therapy 1984;22(4): 349-66.

Subhi 2009 \{published data only\}

Subhi, B. Community orientation and promotion and home injuries prevention among Arab children is Israel. BASPCAN Seventh National Congress. Swansea, 2009.

Swart 2008 \{published data only\} Swart L, Van Niekerk A, Seedat M, Jorddann E. Paraprofessional home visitation program to prevent childhood unintentional injuries in low-income communities: a cluster randomized controlled trial. Injury Prevention 2008;14(3):164-9.

Taban 2001 \{published data only\}

Taban N, Lutzker JR. Consumer evaluation of an ecobehavioural program for prevention and intervention of child maltreatment. Journal of Family Violence 2001;16(3): 323-30. 
Trudeau 2010 \{published data only\}

Trudeau J, Stephens Stidhams S, Istre GR, Weir C, Johnson

$\mathrm{U}$. Using lay home educators to provide safety messages in Dallas, TX, USA. 10th World Conference on Injury Prevention and Safety Promotion. London, 2010.

Tsoumakas 2009 \{published data only\}

Tsoumakas K, Dousis E, Mavridi F, Gremou A, Matziou V. Parent's adherence to children's home-accident preventive measures. International Nursing Review 2009;56(3): 369-374.

Van As, 2006 \{published data only\}

Van As A. Creating a safer environment for children: the need for an integrative family approach. 8th World conference on Injury Prevention and Safety Promotion. South Africa. South Africa, 2006.

\section{Additional references}

\section{Barlow 2000}

Barlow J, Stewart-Brown S. Behavior problems and groupbased parent education programs. Journal of Developmental and Behavioral Pediatrics 2000;21(5):356-70.

\section{Barlow 2002}

Barlow J, Coren E, Stewart-Brown S. Meta-analysis of parenting programmes in improving maternal psychosocial health. British Journal of General Practice 2002;52:223-33.

Barlow 2003

Barlow J, Parsons J. Group-based parent-training programmes for improving emotional and behavioural health adjustment in 0-3 children. Cochrane Database of Systematic Reviews 2003, Issue 2. [DOI: 10.1002/ 14651858.CD003680]

\section{Barlow 2006}

Barlow J, Johnston I, Kendrick D, Polnay L, Stewart-Brown $S$. Individual and group-based parenting programmes for the treatment of physical abuse and neglect. Cochrane Database of Systematic Reviews 2006, Issue 3. [DOI: 10.1002/14651858.CD005463.pub2]

Barlow 2008

Barlow J, Davis H, McIntosh E, Kirkpatrick E, Peters R, Jarrett P, et al.The Oxfordshire Home Visiting study. Unpublished report 2008.

Beautrais 1981

Beautrais AL, Fergusson DM, Shannon FT. Accidental poisoning in the first three years of life. Australian Paediatric Journal 1981;17(2):104-9.

Beautrais 1982

Beautrais AL, Fergusson DM, Shannon FT. Life events and childhood morbidity: a prospective study. Pediatrics 1982; 70(6): $935-40$.

\section{Bijur 1986}

Bijur PE, Stewart-Brown S, Butler N. Child behavior and accidental injury in 11,966 preschool children. American Journal of Diseases of Children 1986;140(5):487-92.

\section{Bijur 1988a}

Bijur P, Golding J, Haslum M, Kurzon M. Behavioral predictors of injury in school-age children. American Journal of Diseases of Children 1988;142(12):1307-12.

Bijur 1988b

Bijur PE, Golding J, Haslum M. Persistence of occurrence of injury: can injuries of preschool children predict injuries of school-aged children?. Pediatrics 1988;82(5):707-12.

Bradbury 1999

Bradbury K, Janicke DM, Riley AW, Finney JW. Predictors of unintentional injuries to school-age children seen in pediatric primary care. Journal of Pediatric Psychology 1999; 24(5):423-33.

\section{Brown 1978}

Brown GW, Davidson S. Social class, psychiatric disorder of mother, and accidents to children. Lancet 1978;1(8060): 378-81.

\section{Bussing 1996}

Bussing R, Menvielle E, Zima B. Relationship between behavioral problems and unintentional injuries in US children. Findings of the 1988 National Health Interview Survey. Archives of Pediatrics \& Adolescent Medicine 1996; 150(1):50-6.

\section{Caldwell 2003}

Caldwell BM, Bradley RH. Home Observation for Measurement of the Environment. Administration manual. Arizona: Tempe, AZ: Family \& Human Dynamics Research Institute, Arizona State University, 2003.

\section{Coren 2002}

Coren E, Barlow J, Stewart-Brown S. Systematic review of the effectiveness of parenting programmes for teenage parents. Journal of Adolescence 2002;26(1):79-103.

\section{DTI 2003}

Department of Trade and Industry. 24th (final) report of the Home and Leisure Accident Surveilance System 2000, 2001, 2002 data. Department of Trade and Industry, London 2003.

\section{Duggan 2004}

Duggan A, McFarlane E, Fuddy L, Burrell L, Higman SM, Windham $A$, et al.Randomized trial of a statewide home visiting program: impact in preventing child abuse and neglect. Child Abuse and Neglect 2004;28:597-622.

\section{Duggan 2007}

Duggan A, Caldera D, Rodriguez K, Burrell L, Rohde C, Crowne SS. Impact of a statewide home visiting program to prevent child abuse. Child Abuse and Neglect 2007;31: $801-827$.

\section{Edwards 2006}

Edwards P, Green J, Roberts I, Lutchmun S. Deaths from injury in children and employment status in family: analysis of trends in class specific death rates. British Medical Journal 2006;333:119-21.

\section{Elkan 2000}

Elkan R, Kendrick D, Hewitt M, Robinson JJ, Tolley $\mathrm{K}$, Blair $\mathrm{M}$, et al.The effectiveness of domiciliary health 
visiting: a systematic review of international studies and a selective review of the British literature. Health Technology Assessment 2000;4(13):1-339.

\section{Fraser 2000}

Fraser JA, Armstrong KL, Morris JP, Dadds MR. Home visiting intervention for vulnerable families with newborns: follow-up results of a randomized controlled trial. Child Abuse and Neglect 2000;24(11):1399-1429.

\section{Goodson 2000}

Goodson BD, Layzer JI, St. Pierre RG, Bernstein L, Lopez M. Effectiveness of a comprehensive, five-year family support program for low-income children and their families: findings from the Comprehensive Child Development Program. Early Childhood Research Quarterly 2000;15(1): 5-39.

\section{Harris 1994}

Harris MJ, Kotch JB. Unintentional infant injuries: sociodemographic and psychosocial factors. Public Health Nursing 1994;11(2):90-7.

\section{Higgins 2005}

Higgins JPT, Green S, Editors. Cochrane Handbook for Systematic Reviews of Interventions 4.2.5 [updated May 2005]. http://www.cochrane.org/resources/handbook/ hbook.htm.

\section{Hippisley-Cox 2002}

Hippisley-Cox J, Groom L, Kendrick D, Coupland C, Webber E, Savelyich B. Cross-sectional survey of socioeconomic variations in severity and mechanism of childhood injuries in Trent 1992-7. British Medical Journal 2002;324:1132-4.

Hunt 2003

Hunt C. The parenting puzzle - how to get the best out of family life. The parenting puzzle - how to get the best out of family life. Oxford: Family Links, 2003.

\section{Johnson 2000}

Johnson Z, Molloy B, Scallan E, Fitzpatrick P, Rooney B, Keegan T, et al.Community Mothers programme - seven year follow-up of a randomized controlled trial of nonprofessional intervention in parenting. Journal of Public Health Medicine 2000;22(3):337-342.

\section{Johnston 2006}

Johnston BD, Huebner CE, Anderson ML, Tyll LT, Thompson RS. Healthy Steps in an in integrated delivery system. Child and parent outcomes at 30 months. Archives of Pediatric and Adolescent Medicine 2006;160:793-800.

\section{Kemp 2008}

Kemp L, Harris E, McMahon C, Matthey S, Vimpani G, Anderson T, et al.Miller Early Childhood Sustained Home-visiting (MESCH) trial: design, method and sample description. BMC Public Health 2008;8:424-435.

\section{Kendrick 1999}

Kendrick D, Marsh P, Fielding K, Miller P. Preventing injuries in children: cluster randomised controlled trial in primary care. British Medical Journal 1999;318:980-3.

\section{Kendrick 2000}

Kendrick D, Elkan R, Hewitt M, Dewey M, Blair M, Robinson J, et al.Does home visiting improve parenting and the quality of the home environment? A systematic review and meta analysis. Archives of Disease in Childhood 2000;82 (6):443-51

\section{Kendrick 2012}

Kendrick D, Young B, Mason-Jones AJ, Ilyas N, Achana FA, Cooper NJ, et al.Home safety education and provision of safety equipment for injury prevention. Cochrane Database of Systematic Reviews 2012, Issue 9. [DOI: 10.1002/ 14651858.CD005014.pub3]

\section{Lam 2005}

Lam LT. Attention deficit disorder and hospitalisation owing to intra- and interpersonal violence among children and young adolescents. Journal of Adolescent Health 2005; 36(1):19-24.

\section{McLennan 2000}

McLennan JD, Kotelchuck M. Parental prevention practices for young children in the context of maternal depression. Pediatrics 2000;105(5):1090-5.

\section{Miller 2004}

Miller AR, Brehaut JC, Raina P, McGrail KN, Armstrong RW. Use of medical services by methlyphenidate-treated children in the general population. Ambulatory Pediatrics 2004; $4(2): 174-80$.

\section{O'Connor 2000}

O'Connor TG, Davies L, Dunn J, Golding J. Distribution of accidents, injuries, and illnesses by family type. ALSPAC Study Team. Avon Longitudinal Study of Pregnancy and Childhood. Pediatrics 2000;106(5):E68.

\section{Olds 1994}

Olds DL, Henderson Jr CR, Kitzman H. Does prenatal and infancy nurse home visitation have enduring effects on qualities of parental caregiving and child health at 25 to 50 months of life?. Pediatrics 1994;93(1):89-98.

\section{ONS 2009}

Office for National Statistics. Mortality statistics: deaths registered in 2008 DDRR “ 0078. Review of the National Statistician on deaths in England and Wales, 2008. http:// www.statistics.gov.uk/downloads/theme health/DR2008/ DR 08.pdf. (Accessed 9.12.10).. London: Office for National Statistics, 2009.

\section{Roberts 1996}

Roberts I, Power C. Does the decline in child injury mortality vary by social class? A comparison of class specific mortality in 1981 and 1991. British Medical Journal 1996; 313:784-6.

\section{Roberts 1996b}

Roberts I, Kramer MS, Suissa S. Does home visiting prevent childhood injury? A systematic review of randomised controlled trials. British Medical Journal 1996;312:29-33.

\section{Roberts 1997}

Roberts I. Cause specific social class mortality differentials for child injury and poisoning in England and Wales. 
Journal of Epidemiology \& Community Health 1997;51: 334-5.

Rowe 2004

Rowe R, Maughan B, Goodman R. Childhood psychiatric disorder and unintentional injury: findings from a national cohort study. Journal of Pediatric Psychology 2004;29(2): 119-30.

\section{Sanders 2002}

Sanders M, Markie-Dadds C, Turner KMT, BrechmanToussaint M. Triple P: A guide to the system. Queensland: Triple P International, 2002.

\section{Schwebel 2004}

Schwebel DC, Brezausek CM, Ramey SL, Ramey CT. Interactions between child behavior patterns and parenting: implications for children's unintentional injury risk. Journal of Pediatric Psychology 2004;29:93-104.

\section{Smithson 2011}

Smithson J, Garside R, Pearson M. Barriers to, and facilitators of, the prevention of unintentional injury in children in the home: a systematic review and synthesis of qualitative research. Injury Prevention 2011;17(2):119-26.

\section{Soubhi 2004}

Soubhi H. The social context of childhood injury in Canada: integration of the NLSCY findings. American Journal of Health Behavior 2004;28 (Suppl 1):S38-S50.

\section{The NHS Information Centre 2007}

The NHS Information Centre. Hospital Episode Statistics (HES). www.hesonline.nhs.uk (Accessed 9.12.10) 2007.

\section{Totsika 2004}

Totsika V, Sylva K. The Home Observation for Measurement of the Environment Revisited. Child and Adolescent Mental Health 2004;9(1):25-35.

\section{UNICEF 2001}

UNICEF. A league table of child deaths by injury in rich nations. Innocenti report card Issue no. 2. Florence: Unicef. Innocenti Research Centre, February 2001.

\section{Zwi 2011}

Zwi M, Jones H, Thorgaard C, York A, Dennis JA. Parent training interventions for Attention Deficit Hyperactivity Disorder (ADHD) in children aged 5 to 18 years. Cochrane Database of Systematic Reviews 2011, Issue 12. [DOI: 10.1002/14651858.CD003018.pub3]

* Indicates the major publication for the study 


\title{
CHARACTERISTICS OF STUDIES
}

\section{Characteristics of included studies [ordered by study ID]}

\author{
Armstrong 2000
}

\begin{tabular}{|c|c|}
\hline Methods & Randomised controlled trial. \\
\hline Participants & $\begin{array}{l}\text { Families of newborns at inner-city obstetric hospital, with English literacy skills sufficient } \\
\text { to complete study questionnaire and any one of: } \\
\text { physical domestic violence, child abuse of either parent, single parent, ambivalence to } \\
\text { pregnancy; or } 3 \text { or more of: maternal age }<18 \text { years, } 3 \text { or more household moves in last } 2 \\
\text { years, financial stress, }<10 \text { years maternal education, low income, social isolation, history } \\
\text { of mental health disorder, drug or alcohol abuse in either parent, domestic violence other } \\
\text { than physical abuse }\end{array}$ \\
\hline Interventions & $\begin{array}{l}\text { Intervention arm: Home visits weekly for first } 6 \text { weeks, } 2 \text { weekly from } 6 \text { weeks to } 3 \\
\text { months of age, monthly from } 3 \text { to } 6 \text { months of age. Home visits comprised manualised } \\
\text { programme aimed at enhancing parent's relationship with the infant and positively in- } \\
\text { fluencing ability to provide a safer more nurturing and healthier environment for their } \\
\text { child. Focus of home visits was to establish trust with family, enhancing parental self- } \\
\text { esteem and confidence, providing anticipatory guidance for normal child development } \\
\text { problems such as sleeping or crying behaviour problems, promoting preventive child } \\
\text { health care and facilitating access to community services. In addition brief social work } \\
\text { intervention was offered to families experiencing partnership or grief difficulties. Home } \\
\text { visits provided by child health nurse. } \\
\text { Control arm: conventional community child health services, which includes offer of one } \\
\text { home visit from child health nurse and child health centre visits by appointment }\end{array}$ \\
\hline Outcomes & $\begin{array}{l}\text { Parental reported injury including bruises, scratches, burns and unspecified injury. } \\
\text { HOME inventory including subscales "organization of the home environment" and } \\
\text { "provision of play materials" }\end{array}$ \\
\hline Notes & $\begin{array}{l}\text { Allocation concealment: by clerical officer not involved in determining eligibility for } \\
\text { study using computer generated random number list. } \\
\text { Detection bias: outcome assessors blinded to treatment arm allocation. } \\
\text { Attrition bias: } \\
\text { At start of study: } \\
\text { Intervention arm } n=90 \\
\text { Control arm } n=91 \\
\text { At } 4 \text { months follow up: } \\
\text { Intervention arm } n=80 / 90(88.9 \%) \\
\text { Control arm } n=80 / 91(87.9 \%) \\
\text { Data from } 12 \text { month follow up reported in Fraser } 2000\end{array}$ \\
\hline
\end{tabular}




\begin{tabular}{|c|c|c|}
\hline $\begin{array}{l}\text { Random sequence generation (selection } \\
\text { bias) }\end{array}$ & Low risk & "A random number table was computer generated" \\
\hline Allocation concealment (selection bias) & Low risk & $\begin{array}{l}\text { Allocation was by "a clerical officer not involved in de- } \\
\text { termining eligibility to determine intervention status." }\end{array}$ \\
\hline $\begin{array}{l}\text { Blinding of participants and personnel } \\
\text { (performance bias) } \\
\text { All outcomes }\end{array}$ & High risk & Unable to blind participants and study personnel \\
\hline $\begin{array}{l}\text { Blinding of outcome assessment (detection } \\
\text { bias) } \\
\text { All outcomes }\end{array}$ & Low risk & $\begin{array}{l}\text { "Data collected by a researcher naive to the intervention } \\
\text { status of the participants" }\end{array}$ \\
\hline $\begin{array}{l}\text { Incomplete outcome data (attrition bias) } \\
\text { All outcomes }\end{array}$ & Low risk & Attrition rate of $12 \%$ \\
\hline Selective reporting (reporting bias) & Low risk & All outcomes reported \\
\hline Other bias & Low risk & $\begin{array}{l}\text { Not reported whether intention to treat analysis under- } \\
\text { taken. Appears to be free of other biases }\end{array}$ \\
\hline
\end{tabular}

Barlow 2007

\begin{tabular}{|c|c|}
\hline Methods & Randomised controlled trial \\
\hline Participants & $\begin{array}{l}\text { Vulnerable women who were identified during pregnancy by community midwives at- } \\
\text { tached to one of } 40 \text { participating GP practices using a range of demographic and socio- } \\
\text { economic criteria (i.e. risk factors) such as mental health problems, domestic violence, } \\
\text { drug and alcohol abuse and housing problems }\end{array}$ \\
\hline Interventions & $\begin{array}{l}18 \text { months of weekly visits starting during the second trimester of pregnancy from } \\
\text { a Health Visitor trained in understanding the process of helping, skills of relating to } \\
\text { parents effectively and methods of promoting parent-infant interaction using the Family } \\
\text { Partnership Model } \\
\text { Parents in both control and intervention group received the standard help that was } \\
\text { available to such families. Women not wanting to be randomised or without a working } \\
\text { understanding of English were excluded }\end{array}$ \\
\hline Outcomes & $\begin{array}{l}\text { Home Observation for Measurement of the Environment (HOME) Inventory was used } \\
\text { to measure the quality of the home environment at } 12 \text { and } 36 \text { months postnatal }\end{array}$ \\
\hline Notes & $\begin{array}{l}\text { Attrition bias: } \\
\text { At the start of the study: } \\
\text { Intervention group } n=68 \\
\text { Control group } n=63 \\
\text { At } 12 \text { months } \\
\text { Intervention group } n=62(91 \%)\end{array}$ \\
\hline
\end{tabular}


Control group $\mathrm{n}=58(92 \%)$

Later follow up data reported in Barlow 2008 (unpublished)

At 36 months

Intervention group $\mathrm{n}=51(77 \%)$

Control group $\mathrm{n}=46(72 \%)$

\section{Risk of bias}

\begin{tabular}{|c|c|c|}
\hline Bias & Authors' judgement & Support for judgement \\
\hline $\begin{array}{l}\text { Random sequence generation (selection } \\
\text { bias) }\end{array}$ & Unclear risk & Not reported \\
\hline Allocation concealment (selection bias) & Low risk & Use of "sequentially numbered sealed opaque envelopes" \\
\hline $\begin{array}{l}\text { Blinding of participants and personnel } \\
\text { (performance bias) } \\
\text { All outcomes }\end{array}$ & High risk & $\begin{array}{l}\text { Participants and those delivering intervention not } \\
\text { blinded }\end{array}$ \\
\hline $\begin{array}{l}\text { Blinding of outcome assessment (detection } \\
\text { bias) } \\
\text { All outcomes }\end{array}$ & Low risk & $\begin{array}{l}\text { "Data were collected, coded and analysed by researchers } \\
\text { who had not been involved in recruitment and were } \\
\text { therefore blind to the intervention group" }\end{array}$ \\
\hline $\begin{array}{l}\text { Incomplete outcome data (attrition bias) } \\
\text { All outcomes }\end{array}$ & Low risk & $\begin{array}{l}\text { Low risk at } 12 \text { months with attrition }<10 \% \text {, high risk at } \\
3 \text { years with attrition } 26 \%\end{array}$ \\
\hline Selective reporting (reporting bias) & Low risk & All outcomes reported \\
\hline Other bias & Low risk & $\begin{array}{l}\text { Intention to treat analysis undertaken. Appears to be free } \\
\text { of other biases }\end{array}$ \\
\hline
\end{tabular}

\section{Caldera 2007}

\begin{tabular}{ll}
\hline Methods & Randomised controlled trial \\
\hline Participants & $\begin{array}{l}\text { Families identified as being at-risk according to a protocol. Families who screen positive } \\
\text { are assessed for risk using Kempe's Family StressChecklist and those scoring greater than } \\
\text { or equal to } 25 \text { are eligible for the HFAK. Half the families are identified prenatally and } \\
\text { half at the time of the child's birth. To be eligible for inclusion participants could not } \\
\text { have previously enrolled in HFAK and had to speak English well enough to complete } \\
\text { study activities }\end{array}$ \\
\hline Interventions & $\begin{array}{l}\text { Voluntary intensive, long term (3 to } 5 \text { years) home visiting. Visits are offered weekly } \\
\text { for the first } 6 \text { to } 9 \text { months with the frequency of visits decreasing as family function- } \\
\text { ing improves. Home visitors are to provide information, make referrals to community } \\
\text { resources,help parents prepare for developmental milestones, screen and refer for devel- } \\
\text { opmental delay, and promote child environmental safety. They are to support positive } \\
\text { parent-child interaction via role modelling and reinforcement of positive interaction and }\end{array}$ \\
\hline
\end{tabular}


Caldera 2007 (Continued)

parental empathy. Use of parenting curricula is encouraged but no specific curriculum is required. Home visitors are to encourage parents to establish a medical home for child health care and to support parents in crises. They are encouraged to use the Individual Family Support Plan (IFSP) as a tool for teaching problem solving around family initiated goals

Outcomes

Home Observation for Measurement of the Environment (HOME) Inventory was used to measure the quality of the home environment

Number of injuries requiring medical care.

\begin{tabular}{ll} 
Notes & Attrition bias: \\
& At the start of the study: \\
& Intervention= 162 \\
& Control=163 \\
& At 24 months, interviews obtained with : \\
Intervention $=138(85 \%)$ & Control=140 $(86 \%)$ \\
For number of injuries, data only available for those with complete medical records \\
Intervention=131 \\
Control=137 \\
\hline
\end{tabular}

Risk of bias

\begin{tabular}{|c|c|c|}
\hline Bias & Authors' judgement & Support for judgement \\
\hline $\begin{array}{l}\text { Random sequence generation (selection } \\
\text { bias) }\end{array}$ & Low risk & Use of "table of random numbers" \\
\hline Allocation concealment (selection bias) & Unclear risk & Not reported \\
\hline $\begin{array}{l}\text { Blinding of participants and personnel } \\
\text { (performance bias) } \\
\text { All outcomes }\end{array}$ & High risk & $\begin{array}{l}\text { Participants and those delivering intervention not } \\
\text { blinded }\end{array}$ \\
\hline $\begin{array}{l}\text { Blinding of outcome assessment (detection } \\
\text { bias) } \\
\text { All outcomes }\end{array}$ & Low risk & $\begin{array}{l}\text { "Trained research staff blinded to family group assign- } \\
\text { ment" collected baseline and follow-up data }\end{array}$ \\
\hline $\begin{array}{l}\text { Incomplete outcome data (attrition bias) } \\
\text { All outcomes }\end{array}$ & Low risk & Attrition rate less than $20 \%$ \\
\hline Selective reporting (reporting bias) & Low risk & No evidence \\
\hline Other bias & Low risk & $\begin{array}{l}\text { Intention to treat analysis undertaken. Appears to be free } \\
\text { of other biases }\end{array}$ \\
\hline
\end{tabular}


Culp 2007

\begin{tabular}{|c|c|}
\hline Methods & Non-randomised controlled trial \\
\hline Participants & First time mothers recruited prior to 28 th week of pregnancy \\
\hline Interventions & $\begin{array}{l}\text { Home visitors provided information, made referrals to community services, screened } \\
\text { and referred for developmental delay and promoted child environmental safety. Home } \\
\text { visiting used an individualized manualised curriculum delivered by professional home } \\
\text { visitors with college degrees in child development. The three major foci were maternal } \\
\text { health, child health and safety and family functioning and parenting. Mothers received } \\
\text { weekly home visits during the first month after enrolment, biweekly for the remainder } \\
\text { of their pregnancy, weekly for the first } 3 \text { months post partum and biweekly for months } \\
3 \text { to } 12 \text { post partum. The health curriculum during the prenatal phase included a min- } \\
\text { imum of four visits sharing information on nutrition, alcohol, smoking, foetal growth } \\
\text { and development, labour and delivery and family planning. The health curriculum from } \\
\text { birth to } 12 \text { months focused on effects of second hand smoke on infant's growth and } \\
\text { development, family planning, immunisations, infant nutrition and health food prepa- } \\
\text { ration. A special emphasis was placed on teaching household safety when the infants } \\
\text { were crawling through the end of the intervention period at } 12 \text { months }\end{array}$ \\
\hline Outcomes & $\begin{array}{l}\text { Massachusetts Home Safety Questionnaire - } 42 \text { items } \\
\text { Number of hospital visits and emergency room visits }\end{array}$ \\
\hline Notes & $\begin{array}{l}\text { Attrition bias: } \\
\text { At start of study } \\
\text { Intervention=205 } \\
\text { Control=150 } \\
\text { At } 12 \text { months } \\
\text { Intervention= } 156(76 \%) \\
\text { Control=107 }(71 \%)\end{array}$ \\
\hline
\end{tabular}

Risk of bias

\begin{tabular}{l|l|l}
\hline Bias & Authors' judgement & Support for judgement \\
\hline $\begin{array}{l}\text { Allocation to intervention/control (selec- } \\
\text { tion bias)(For non randomised and CBA } \\
\text { studies) }\end{array}$ & Unclear risk & $\begin{array}{l}\text { Control sites selected from counties with similar risk } \\
\text { and demographic characteristics }\end{array}$ \\
\hline $\begin{array}{l}\text { Blinding of participants and personnel } \\
\text { (performance bias) } \\
\text { All outcomes }\end{array}$ & High risk & $\begin{array}{l}\text { Participants and those delivering intervention not } \\
\text { blinded }\end{array}$ \\
\hline $\begin{array}{l}\text { Blinding of outcome assessment (detection } \\
\text { bias) } \\
\text { All outcomes }\end{array}$ & Unclear risk & Not reported \\
\hline
\end{tabular}

\begin{tabular}{l|l|l} 
Incomplete outcome data (attrition bias) & High risk & Attrition rate of $26 \%$
\end{tabular}

All outcomes

Parenting interventions for the prevention of unintentional injuries in childhood (Review) 
Culp 2007 (Continued)

\begin{tabular}{l|l|l}
\hline Selective reporting (reporting bias) & Low risk & Appears to report all outcomes \\
\hline Other bias & Low risk & $\begin{array}{l}\text { Intention to treat analysis undertaken. Appears to be } \\
\text { free of other biases }\end{array}$ \\
\hline $\begin{array}{l}\text { Risk of bias due to confounding (For non } \\
\text { randomised and CBA studies) }\end{array}$ & Low risk & $\begin{array}{l}\text { There was an assessment of maternal characteristics } \\
\text { at recruitment and the treatment arms appear similar }\end{array}$ \\
\hline
\end{tabular}

Duggan 1999

Methods

Participants

Interventions

Outcomes

Notes
Randomised controlled trial.

Families with newborns identified as at risk for child abuse or neglect using the Family Stress Checklist which included items such as substance use, poor mental health, domestic violence, history of abuse as a child, unrealistic expectations of child, unwanted pregnancy and other risk of poor bonding

Intervention arm: Home visiting programme for 3-5 years designed to help families cope with the challenges of child rearing (the "Healthy Start Programme"). Programme is aimed at improving family functioning, preventing child abuse and promoting child health. Programme commences with weekly visits which reduce in frequency as family functioning improves. Intervention included helping families to identify and build on strengths to improve family functioning, role modelling of problem solving skills, linking families with needed services, providing parenting education and modelling effective parent-child interaction. Programme sites were allowed flexibility in which parenting curricula they delivered.

Control arm: no "Healthy Start Programme".

Parental reported injury requiring medical care in first 2 years of life.

Hospitalisations for trauma in first 3 years of life.

Selection bias: allocation using predetermined table of random numbers

Detection bias: outcome assessors blinded to treatment group allocation.

Attrition bias:

At start of study:

Intervention arm $\mathrm{n}=373$

Control arm $n=270$

At 2 years follow up:

Intervention arm $\mathrm{n}=309(82.8 \%)$

Control arm $\mathrm{n}=225$ (83.3\%)

Data from 3 years follow up published in Duggan et al. 2004

At 3 years follow up:

Intervention arm $\mathrm{n}=342(92 \%)$

Control arm n=231 (86\%)

Risk of bias

Bias

Authors' judgement

Support for judgement

Parenting interventions for the prevention of unintentional injuries in childhood (Review)

Copyright @ 2013 The Cochrane Collaboration. Published by John Wiley \& Sons, Ltd. 


\section{Duggan 1999 (Continued)}

\begin{tabular}{|c|c|c|}
\hline $\begin{array}{l}\text { Random sequence generation (selection } \\
\text { bias) }\end{array}$ & Low risk & "Table of random numbers" \\
\hline Allocation concealment (selection bias) & Low risk & "Evaluation staff informed EID worker" \\
\hline $\begin{array}{l}\text { Blinding of participants and personnel } \\
\text { (performance bias) } \\
\text { All outcomes }\end{array}$ & High risk & Not blinded \\
\hline $\begin{array}{l}\text { Blinding of outcome assessment (detection } \\
\text { bias) } \\
\text { All outcomes }\end{array}$ & Low risk & Interviewers did not know group status \\
\hline $\begin{array}{l}\text { Incomplete outcome data (attrition bias) } \\
\text { All outcomes }\end{array}$ & Low risk & $\begin{array}{l}\text { Attrition rate } 18 \% \text { at } 2 \text { year follow-up and } 11 \% \text { at } 3 \\
\text { years follow up }\end{array}$ \\
\hline Selective reporting (reporting bias) & Low risk & Does not appear to \\
\hline Other bias & Low risk & $\begin{array}{l}\text { Intention to treat analysis undertaken. Does not appear } \\
\text { to be other biases }\end{array}$ \\
\hline
\end{tabular}

Emond 2002

\begin{tabular}{ll} 
Methods & Controlled before-and-after study (cluster allocated). \\
\hline Participants & First time parents in disadvantaged areas. \\
\hline Interventions & $\begin{array}{l}\text { Intervention arm: Home visits by specially trained health visitor antenatally, at } 10 \text { days } \\
\text { and } 3 \text { weeks post-natally and every } 5 \text { weeks until } 8 \text { months of age. Home visiting pro- } \\
\text { gramme comprised part of the "Child Development Programme" which is based on the } \\
\text { principles of empowerment and is aimed at improving the health and development of } \\
\text { young children by supporting and advising mothers during first phase of parenting using } \\
\text { specially designed written materials and cartoons (First Parent Health Visitor Scheme } \\
\text { (FPHVS). } \\
\text { Control arm: conventional health visiting. }\end{array}$ \\
\hline
\end{tabular}
health visiting bases matched on social, economic and demographic profiles were chosen as comparison bases. Only data from prospective part of study included in this review. Detection bias: unclear if outcome assessors were blinded to treatment group allocation. Attrition bias:

At start of study:

Intervention arm $=205$

Control arm $=254$

At 2 years follow up:

$\mathrm{n}=368(80 \%)$. Number not given by treatment arm but authors repot no significant 
Emond 2002 (Continued)

difference found in attrition rate between arms

Risk of bias

\begin{tabular}{|c|c|c|}
\hline Bias & Authors' judgement & Support for judgement \\
\hline $\begin{array}{l}\text { Allocation to intervention/control (selec- } \\
\text { tion bias)(For non randomised and CBA } \\
\text { studies) }\end{array}$ & High risk & $\begin{array}{l}\text { Intervention areas already } \\
\text { receiving FPHVS. Control areas chosen to } \\
\text { closely match intervention areas on be key } \\
\text { demographic variables }\end{array}$ \\
\hline $\begin{array}{l}\text { Blinding of participants and personnel } \\
\text { (performance bias) } \\
\text { All outcomes }\end{array}$ & High risk & Not blinded \\
\hline $\begin{array}{l}\text { Blinding of outcome assessment (detection } \\
\text { bias) } \\
\text { All outcomes }\end{array}$ & Unclear risk & Not clear \\
\hline $\begin{array}{l}\text { Incomplete outcome data (attrition bias) } \\
\text { All outcomes }\end{array}$ & Low risk & Attrition rate of $20 \%$ \\
\hline Selective reporting (reporting bias) & High risk & Does not report all outcomes \\
\hline Other bias & Unclear risk & Intention to treat analysis not reported \\
\hline $\begin{array}{l}\text { Risk of bias due to confounding (For non } \\
\text { randomised and CBA studies) }\end{array}$ & High risk & $\begin{array}{l}\text { There was an assessment of the distribution } \\
\text { of confounders between treatment arms. } \\
\text { There were some differences between arms } \\
\text { on confounders }\end{array}$ \\
\hline
\end{tabular}

Feldman 1992

\begin{tabular}{ll}
\hline Methods & Randomised controlled trial. \\
\hline Participants & Low IQ mothers at risk of child neglect, with children aged 1-23 months of age \\
\hline Interventions & $\begin{array}{l}\text { Intervention arm: Home based weekly parent training programme focussing on teaching } \\
\text { basic child care skills (e.g. preparing feeds, bottle feeding, crib safety, sleep safety and } \\
\text { toilet training). Training consisted of verbal instruction, specially designed picture books } \\
\text { depicting each stage of the child care task, modelling of each step by trainer, feedback } \\
\text { on mothers performance, plus coupons for small gift items when mothers demonstrated } \\
80 \% \text { of trained skills correctly. Mean duration of training } 7.7 \text { weeks. Training provided } \\
\text { by psychology or early childhood education graduates, trained to deliver the programme. } \\
\text { Control arm: no training }\end{array}$ \\
\hline
\end{tabular}

Outcomes

Demonstrated sleep safety tasks.

Parenting interventions for the prevention of unintentional injuries in childhood (Review) 
Feldman 1992 (Continued)

\begin{tabular}{ll}
\hline Notes & Selection bias: allocation to treatment group by picking numbers out of a hat \\
& Detection bias: outcome assessors not blinded to treatment group allocation. \\
Attrition bias: \\
At start of study: \\
intervention arm $n=11$ \\
Control arm $\mathrm{n}=11$ \\
At follow up (immediately post training or at next home visit): \\
Intervention arm $\mathrm{n}=11(100 \%)$ \\
Control arm $\mathrm{n}=11(100 \%)$ \\
\hline
\end{tabular}

\section{Risk of bias}

\begin{tabular}{|c|c|c|}
\hline Bias & Authors' judgement & Support for judgement \\
\hline $\begin{array}{l}\text { Random sequence generation (selection } \\
\text { bias) }\end{array}$ & Unclear risk & "Randomly assigned" but no reports on how generated \\
\hline Allocation concealment (selection bias) & High risk & $\begin{array}{l}\text { "Made up slips of paper with numbers on them, folded } \\
\text { them and put then into a hat, shook the hat, reached in } \\
\text { the hat (without looking) and picked a slip out" }\end{array}$ \\
\hline $\begin{array}{l}\text { Blinding of participants and personnel } \\
\text { (performance bias) } \\
\text { All outcomes }\end{array}$ & High risk & Not blinded \\
\hline $\begin{array}{l}\text { Blinding of outcome assessment (detection } \\
\text { bias) } \\
\text { All outcomes }\end{array}$ & Low risk & $\begin{array}{l}\text { "Primary observers and reliability checkers were not told } \\
\text { of the between group experimental design" }\end{array}$ \\
\hline $\begin{array}{l}\text { Incomplete outcome data (attrition bias) } \\
\text { All outcomes }\end{array}$ & Low risk & $\begin{array}{l}\text { For immediate post test attrition was } 0 \% \text {. For later fol- } \\
\text { low-up attrition rate of } 28 \%\end{array}$ \\
\hline Selective reporting (reporting bias) & Low risk & No evidence \\
\hline Other bias & Unclear risk & $\begin{array}{l}\text { Intention to treat analysis not reported. Does not appear } \\
\text { to be other biases }\end{array}$ \\
\hline
\end{tabular}

Fergusson 2005

\begin{tabular}{l|l}
\hline Methods & Randomised controlled trial. \\
\hline Participants & $\begin{array}{l}\text { Families with children aged under } 3 \text { months facing stress and difficulty defined as having } \\
2 \text { or more risk factors identified from screening tool covering parental age, planning of } \\
\text { pregnancy, social support, substance use, financial situation and family violence }\end{array}$ \\
\hline Interventions & $\begin{array}{l}\text { Intervention arm: Home visiting programme (the "Early Start Program"), number of } \\
\text { visits not specified, provided for a mean of } 24 \text { months. Intervention involved use of a } \\
\text { social learning model approach which included assessment of family needs, development }\end{array}$ \\
\hline
\end{tabular}

Parenting interventions for the prevention of unintentional injuries in childhood (Review)

Copyright $\odot 2013$ The Cochrane Collaboration. Published by John Wiley \& Sons, Ltd. 
Fergusson 2005 (Continued)

of positive partnership between family support worker and client, collaborative problem solving to devise solutions to family challenges, provision of support and mentoring and advice to assist families to mobilise their strengths and resources. Home visits provided by family support workers (nurses or social workers). Degree to which the intervention involved the use of a protocol, manual or curriculum is unclear.

Control arm: no "Early Start Program".

Outcomes

Hospital attendance for accident/injury or accidental poisoning in first 3 years of life, obtained from medical records

Notes

Selection bias: allocation using computer generated random number list

Detection bias: unclear if outcome assessors not blinded to treatment group allocation. Attrition bias:

At start of study:

Intervention arm $\mathrm{n}=220$

Control arm $\mathrm{n}=223$

At 36 months follow up:

Intervention arm $=184(84 \%)$

Control arm $=207(93 \%)$

Risk of bias

Bias

Authors' judgement

Support for judgement

Random sequence generation (selection Low risk bias)

“Computer generated sequence of random numbers"

$\begin{array}{lll}\text { Allocation concealment (selection bias) Unclear risk } & \text { Not reported }\end{array}$

Blinding of participants and personnel High risk Not blinded

(performance bias)

All outcomes

Blinding of outcome assessment (detection High risk bias)

"Research interviewers were aware of the treatment

All outcomes group to which the family was assigned"

Incomplete outcome data (attrition bias) Low risk

Follow up rate of $88 \%$

All outcomes

Selective reporting (reporting bias) Low risk $\quad$ Does not appear so

$\begin{array}{lll}\text { Other bias } & \text { Low risk Intention to treat analysis undertaken }\end{array}$ 


\begin{tabular}{|c|c|}
\hline Methods & Randomised controlled trial. \\
\hline Participants & Unmarried primigravidas aged $15-18$ years in low income areas \\
\hline Interventions & $\begin{array}{l}\text { Intervention arm: Extensive child health supervision with emphasis on counselling and } \\
\text { anticipatory guidance (based on "Baby and well child care" by Benjamin Spock), plus well } \\
\text { child care provided by paediatrician and nurse using mobile coach which visited child's } \\
\text { home making } 9,6 \text { and } 4 \text { visits in } 1 \text { st, } 2 \text { nd and } 3 \text { rd year of life. Cognitive stimulation } \\
\text { programme provided by nurse home visits ( } 10,8 \text { and } 6 \text { visits in } 1 \text { st, } 2 \text { nd and } 3 \text { rd years } \\
\text { of life). Programme covered age appropriate forms of visual, auditory, tactile and motor } \\
\text { types of stimulation with particular emphasis on language development. Group sessions } \\
\text { for parents ( } 16 \text { over } 1 \text { year) to discuss child rearing practices and other child and family } \\
\text { problems. } \\
\text { Control arm: conventional care including one home visit by nurse and paediatrician in } \\
\text { neonatal period and referral to well-baby clinic }\end{array}$ \\
\hline Outcomes & Number of toxic ingestions in first 3 years of life. \\
\hline Notes & $\begin{array}{l}\text { Selection bias: assigned using random numbers. } \\
\text { Detection bias: outcome assessors not blinded to treatment group allocation. } \\
\text { At start of study: } \\
\text { Intervention arm } n=47 \\
\text { Control arm } n=48 \\
\text { At } 3 \text { years follow up: } \\
\text { Intervention arm } n=44(94 \%) \\
\text { Control arm } n=45(94 \%)\end{array}$ \\
\hline
\end{tabular}

\section{Risk of bias}

\begin{tabular}{l|l|l}
\hline Bias & Authors' judgement & Support for judgement \\
\hline $\begin{array}{l}\text { Random sequence generation (selection } \\
\text { bias) }\end{array}$ & Unclear risk & $\begin{array}{l}\text { “Assigned by a series of random numbers" but it is not } \\
\text { clear how it is generated }\end{array}$ \\
\hline $\begin{array}{l}\text { Allocation concealment (selection bias) } \\
\begin{array}{l}\text { Blinding of participants and personnel } \\
\text { (performance bias) } \\
\text { All outcomes }\end{array}\end{array}$ & High risk & Potearticipants and personnel not blinded \\
\hline
\end{tabular}

\begin{tabular}{|c|c|c|}
\hline $\begin{array}{l}\text { Blinding of outcome assessment (detection } \\
\text { bias) } \\
\text { All outcomes }\end{array}$ & High risk & $\begin{array}{l}\text { Project nurse and paediatrician collected information on } \\
\text { control and experimental series }\end{array}$ \\
\hline
\end{tabular}

All outcomes

\begin{tabular}{l|l} 
Incomplete outcome data (attrition bias) & Low risk $\quad$ Attrition rate of $6 \%$
\end{tabular}

All outcomes

\begin{tabular}{l|ll} 
Selective reporting (reporting bias) & High risk & Mainly significant findings reported
\end{tabular} 
Gutelius 1977 (Continued)

Other bias

Unclear risk

Intention to treat analysis not reported. Does not appear to be other bias

Hardy 1989

\begin{tabular}{|c|c|}
\hline Methods & Quasi randomised controlled trial \\
\hline Participants & Inner-city black mothers aged 18 years and older with infants weighing $>2000 \mathrm{~g}$ \\
\hline Interventions & $\begin{array}{l}\text { Intervention arm: } 10 \text { home visits from } 7-10 \text { days to } 24 \text { months of age. Curriculum, plus } \\
\text { single-issue pamphlets aimed at developing parenting and child care skills, including } \\
\text { topics such as well child care, sick child care, feeding, clothing, safety. Anticipatory guid- } \\
\text { ance was given, developmental milestones discussed and suggestions made for enhancing } \\
\text { development. } \\
\text { Referral to social worker or educator for psychosocial issues. } \\
\text { Home visits provided by specially trained local ex-resident working under supervision } \\
\text { of education specialist and social worker. } \\
\text { Control arm: conventional medical, developmental and social assessments with referral } \\
\text { to other services as indicated. No home visits or attendances at child development centres } \\
\text { or at parent groups }\end{array}$ \\
\hline Outcomes & Closed head trauma, obtained from maternal report verified by hospital records \\
\hline Notes & $\begin{array}{l}\text { Selection bias: alternate allocation based on odd (intervention arm) and even (control } \\
\text { arm) medical record numbers } \\
\text { Detection bias: unclear whether outcome assessors were blinded to treatment group } \\
\text { allocation. } \\
\text { Risk of bias due to confounding: treatment arms comparable in terms of \% families } \\
\text { eligible for Medicaid and \% noted to be at "high risk" of illness, developmental problems, } \\
\text { neglect or abuse in medical records. Authors state that age range of children similar in } \\
\text { both groups, but no figures given. } \\
\text { Attrition bias: } \\
\text { At start of study: } \\
\text { Intervention arm } n=143 \\
\text { Control arm } n=147 \\
\text { At } 23 \text { months follow up: } \\
\text { Intervention arm } n=131(92 \%) \\
\text { Control arm } n=132(90 \%)\end{array}$ \\
\hline
\end{tabular}

Risk of bias

Bias

Authors' judgement

Support for judgement

Allocation to intervention/control (selec- Low risk tion bias)(For non randomised and CBA studies)

Based on odd/even medical record number. "Infants whose medical history numbers ended in even digits served as control subjects"

Parenting interventions for the prevention of unintentional injuries in childhood (Review) 
Hardy 1989 (Continued)

\begin{tabular}{l|l|l}
\hline $\begin{array}{l}\text { Blinding of participants and personnel } \\
\text { (performance bias) } \\
\text { All outcomes }\end{array}$ & High risk & Participants and personnel not blinded \\
\hline $\begin{array}{l}\text { Blinding of outcome assessment (detection } \\
\text { bias) } \\
\text { All outcomes }\end{array}$ & Unclear risk & Not reported \\
\hline $\begin{array}{l}\text { Incomplete outcome data (attrition bias) } \\
\text { All outcomes }\end{array}$ & Low risk & Attrition rate of 9\% \\
\hline $\begin{array}{l}\text { Selective reporting (reporting bias) } \\
\text { Other bias }\end{array}$ & Low risk & Low risk \\
\hline $\begin{array}{l}\text { Risk of bias due to confounding (For non } \\
\text { randomised and CBA studies) }\end{array}$ & Low risk & $\begin{array}{l}\text { Antention to treat analysis undertaken. Appears to } \\
\text { be free of other biases }\end{array}$ \\
\hline
\end{tabular}

IHDP 1990

\begin{tabular}{|c|c|}
\hline Methods & Randomised controlled trial. \\
\hline Participants & Low birth weight $(<=2500 \mathrm{~g})$ premature $(<=37$ weeks gestation) infants \\
\hline Interventions & $\begin{array}{l}\text { Intervention arm: Weekly home visits in first year of life and } 2 \text { weekly visits from } 1 \text { to } 3 \\
\text { years of age. Home visits focused on } 2 \text { curricula: } \\
\text { (a) curriculum emphasising cognitive, linguistic and social development and } \\
\text { (b) curriculum designed to provide a systematic approach to help parents manage self } \\
\text { identified problems. Home visits provided by non-professionals. Plus attendance at child } \\
\text { development centres from age } 12 \text { to } 36 \text { months and } 2 \text { monthly parent groups from age } \\
12 \text { months providing information on child rearing, health and safety as well as parent } \\
\text { support (the "Infant Health Development Program"). } \\
\text { Control arm: usual care. }\end{array}$ \\
\hline Outcomes & Maternal reports of injuries not requiring hospital care. \\
\hline Notes & $\begin{array}{l}\text { Selection bias: allocation by independent computer programme } \\
\text { Detection bias: outcome assessors not blinded to treatment arm allocation. } \\
\text { At start of study: } \\
\text { Intervention arm } n=377 \\
\text { Control arm } n=608 \\
\text { At } 24 \text { months follow up; } \\
\text { Intervention arm } n=345(92 \%) \\
\text { Control arm } n=551(91 \%)\end{array}$ \\
\hline
\end{tabular}

\section{Risk of bias}

Parenting interventions for the prevention of unintentional injuries in childhood (Review) 
IHDP 1990 (Continued)

\begin{tabular}{l|ll}
\hline Bias & Authors' judgement & Support for judgement \\
\hline $\begin{array}{l}\text { Random sequence generation (selection } \\
\text { bias) }\end{array}$ & Unclear risk & Not reported \\
\hline $\begin{array}{l}\text { Allocation concealment (selection bias) } \\
\text { Blinding of participants and personnel }\end{array}$ & High risk & $\begin{array}{l}\text { Not clear, reportedly performed by the National Study } \\
\text { Office }\end{array}$ \\
\hline $\begin{array}{l}\text { All outcomes } \\
\text { Blinding of outcome assessment (detection } \\
\text { bias) } \\
\text { All outcomes }\end{array}$ & High risk & Not blinded \\
\hline $\begin{array}{l}\text { Incomplete outcome data (attrition bias) } \\
\text { All outcomes }\end{array}$ & Low risk & $\begin{array}{l}\text { Blinded for cognitive, behavioural and growth assess- } \\
\text { ments }\end{array}$ \\
\hline \begin{tabular}{l} 
Selective reporting (reporting bias) \\
\hline $\begin{array}{l}\text { Other bias }\end{array}$
\end{tabular} & Low risk & Follow up rate of 91\% \\
\hline
\end{tabular}

\section{Johnson 1993}

\begin{tabular}{|c|c|}
\hline Methods & Randomised controlled trial. \\
\hline Participants & First time mothers living in a deprived area. \\
\hline Interventions & $\begin{array}{l}\text { Intervention arm: Monthly home visits by community mother to provide support and } \\
\text { encouragement to first time parents in rearing children using the "Child Development } \\
\text { Programme", including modules on educational development, language development } \\
\text { and cognitive development. } \\
\text { Control arm: conventional public health nurse input including home visits at birth and } \\
\text { six weeks and at other times as required }\end{array}$ \\
\hline Outcomes & Maternal reports of injuries. \\
\hline Notes & $\begin{array}{l}\text { Selection bias: randomisation using sealed opaque envelopes. } \\
\text { Detection bias: outcome assessors not blinded to treatment group allocation. } \\
\text { Attrition bias: } \\
\text { At start of study: } \\
\text { Intervention arm } n=141 \\
\text { Control arm } n=121 \\
\text { At } 12 \text { months follow up: } \\
\text { Intervention arm } n=127(90 \%) \\
\text { control arm } n=105(87 \%) \\
\text { Later follow up data reported in Johnson } 2000\end{array}$ \\
\hline
\end{tabular}


Johnson 1993 (Continued)

At 7 years follow up:

Intervention arm $\mathrm{n}=38(27 \%)$

Control arm n=38 (31\%)

Risk of bias

\begin{tabular}{|c|c|c|}
\hline Bias & Authors' judgement & Support for judgement \\
\hline $\begin{array}{l}\text { Random sequence generation (selection } \\
\text { bias) }\end{array}$ & Low risk & Table of random numbers \\
\hline Allocation concealment (selection bias) & Low risk & "Cards were sealed in consecutively marked envelopes" \\
\hline $\begin{array}{l}\text { Blinding of participants and personnel } \\
\text { (performance bias) } \\
\text { All outcomes }\end{array}$ & High risk & Not blinded \\
\hline $\begin{array}{l}\text { Blinding of outcome assessment (detection } \\
\text { bias) } \\
\text { All outcomes }\end{array}$ & High risk & Not blinded \\
\hline $\begin{array}{l}\text { Incomplete outcome data (attrition bias) } \\
\text { All outcomes }\end{array}$ & Low risk & Follow up rate of $89 \%$ \\
\hline Selective reporting (reporting bias) & Low risk & Appears to report all outcomes \\
\hline Other bias & Unclear risk & $\begin{array}{l}\text { Intention to treat analyses not reported. Does not appear } \\
\text { to be other biases }\end{array}$ \\
\hline
\end{tabular}

Johnston 2004

Methods

Participants

Interventions

\section{Non-randomised controlled trial.}

Pregnant women of less than 22 weeks gestation receiving care from a participating clinic, younger than 45 years, English speaking and planning to use a study clinic for paediatric care

Intervention: Healthy Steps for Young Children programme (HS) beginning prenatally (PP $+\mathrm{HS})$ or postnatally (HS). HS consists of risk reduction activities and universal components including developmental screening, anticipatory guidance and follow-up services offered to all families receiving care. HS participants received postnatal home visits, developmental advice and parent-initiated telephone support, developmental assessments conducted in tandem with scheduled well-child care, the Reach Out and Read literacy program and other risk based screening services and parenting classes delivered by HS specialists. PP participants also received 3 home visits when they were approximately 20, 27 and 34 weeks gestation. PP participants received home visits to help parents create a safe, knowing and welcoming environment for their newborn, and screening and intervention for targeted risk factors such as smoking, depression and domestic violence Control: usual paediatric care. 
Outcomes
Safety practices including safe sleep practices and Home Safety Index comprising items on car seat use, safe storage of firearms, functioning smoke detector, scald prevention activities and safe infant sleeping practices. Results at 3 months post partum

Selection bias: allocation to treatment groups not described

Detection bias: unclear if outcome assessors were blinded to treatment group

Attrition bias:

At start of study:

Intervention arm $\mathrm{n}=304(\mathrm{PP}+\mathrm{HS}=151, \mathrm{HS}=152)$

Control arm $\mathrm{n}=136$

At 3 months follow up:

Intervention arm $\mathrm{n}=275(\mathrm{PP}+\mathrm{HS}=139(92.7 \%), \mathrm{HS}=136(90.1 \%))$

Control arm n=121 (89.7\%)

Later follow up described in Johnston 2006

At 30 month follow up, follow up of

intervention arm PP + HS = $122(81 \%), \mathrm{HS}=117(77 \%)$

control arm $=104(76 \%)$

\section{Risk of bias}

\section{Bias} tion bias)(For non randomised and CBA studies)

\section{Support for judgement}

Does not report how intervention and treatment clinics chosen

Participants and personnel not blinded. Participants may have been unaware of control/intervention clinics as clinics geographically distant

Not reported
Blinding of participants and personnel High risk (performance bias)

All outcomes
Unclear risk

Blinding of outcome assessment (detection Unclear risk bias)

All outcomes

Incomplete outcome data (attrition bias) Low risk

All outcomes

\begin{tabular}{l|l}
\hline Selective reporting (reporting bias) & Low risk \\
\hline Other bias & Low risk \\
\hline $\begin{array}{l}\text { Risk of bias due to confounding (For non } \\
\text { randomised and CBA studies) }\end{array}$ & High risk \\
\hline
\end{tabular}

Follow up rate of $91 \%$ at 3 months. At 30 month follow up, follow up of intervention arm $\mathrm{PP}+\mathrm{HS}=122(81 \%), \mathrm{HS}=117$ $(77 \%)$ control arm $=104(76 \%)$

Does not appear selective reporting

Intention to treat analysis undertaken

There was an assessment of the distribution of confounders between treatment arms and there were significant differences between arms on maternal education and age 


\begin{tabular}{|c|c|}
\hline Methods & Randomised controlled trial \\
\hline Participants & $\begin{array}{l}\text { Mothers reporting one or more of the following risk factors: aged under } 19 \text { years, current } \\
\text { probable distress (assessed as an Edinbugh Dpression Scale (EDS) score of } 10 \text { or more) } \\
\text {, lack of emotional and practical support, late antenatal care (after } 20 \text { weeks gestation) } \\
\text {, major stressors in the past } 12 \text { months, current substance misuse, current or history of } \\
\text { mental health problem or disorder, history of abuse in mother's own childhood, and } \\
\text { history of domestic violence }\end{array}$ \\
\hline Interventions & $\begin{array}{l}\text { Women received an average of } 16.3 \text { (range } 0-52 \text { ) visits, each of } 60-90 \text { min duration } \\
\text { by a child health nurse commencing at on average } 26 \text { weeks gestation (range 12-40) } \\
\text { and continuing to their child's second birthday (average duration of participation in the } \\
\text { programme to child age } 57.0 \text { weeks (range } 0-122 \text { ): } 82 \% \text { visited prenatally, } 95 \% \text { visited } \\
\text { in the first year postnatally and } 53 \% \text { visited in the second year } \\
\text { All women received usual antenatal midwifery, obstetric and birthing services }\end{array}$ \\
\hline Outcomes & $\begin{array}{l}\text { HOME score at } 12 \text { and } 24 \text { months. Subscale data provided on "organisation of envi- } \\
\text { ronment" and provision of appropriate play materials". Data collected at baseline and 1, } \\
6,1218 \text { and } 24 \text { months postnatally }\end{array}$ \\
\hline Notes & $\begin{array}{l}\text { Attrition bias: } \\
\text { At baseline: } \\
\text { intervention arm } \mathrm{n}=111 \\
\text { control arm } \mathrm{n}=97 \\
\text { At } 1 \text { month follow-up } \\
\text { intervention arm } \mathrm{n}=111(100 \%) \\
\text { control arm } \mathrm{n}=97(100 \%) \\
\text { At } 12 \text { month follow-up } \\
\text { intervention arm } \mathrm{n}=89(80 \%) \\
\text { control arm } \mathrm{n}=80(83 \%) \\
\text { At } 18 \text { month follow-up } \\
\text { intervention arm } \mathrm{n}=86(78 \%) \\
\text { control arm } \mathrm{n}=75(77 \%) \\
\text { At } 24 \text { month follow-up } \\
\text { intervention arm } \mathrm{n}=85(77 \%) \\
\text { control arm } \mathrm{n}=69(71 \%) \\
\text { Further data published in Kemp et al. } 2008 \\
\text { At } 36 \text { month follow-up } \\
\text { intervention arm } \mathrm{n}=72(65 \%) \\
\text { control arm } \mathrm{n}=58(60 \%)\end{array}$ \\
\hline
\end{tabular}

Risk of bias

Bias

Random sequence generation (selection Unclear risk bias)

\section{Support for judgement}

A permuted block design was used to randomly allocate mothers to the intervention or comparison group. Blocks varied in size from 0 to 6 . Within each weekly block, a random selection of cases to receive intervention was 
Kemp 2011 (Continued)

made using SPSS

\begin{tabular}{|c|c|c|}
\hline Allocation concealment (selection bias) & Low risk & $\begin{array}{l}\text { Women were given " a sealed envelope that contained } \\
\text { information advising them of their group assignment" }\end{array}$ \\
\hline $\begin{array}{l}\text { Blinding of participants and personnel } \\
\text { (performance bias) } \\
\text { All outcomes }\end{array}$ & High risk & Not possible \\
\hline $\begin{array}{l}\text { Blinding of outcome assessment (detection } \\
\text { bias) } \\
\text { All outcomes }\end{array}$ & High risk & $\begin{array}{l}\text { Outcome data was collected by an RA who was initially } \\
\text { blind to group allocation however, commonly partici- } \\
\text { pants would reveal their group allocation during the data } \\
\text { collection process }\end{array}$ \\
\hline $\begin{array}{l}\text { Incomplete outcome data (attrition bias) } \\
\text { All outcomes }\end{array}$ & High risk & $\begin{array}{l}\text { At } 12 \text { months, follow-up rate of } 82 \% \\
\text { At } 24 \text { months, follow-up rate of } 74 \%\end{array}$ \\
\hline Selective reporting (reporting bias) & High risk & $\begin{array}{l}\text { Unclear which data point HOME scores were used for } \\
\text { the analysis }\end{array}$ \\
\hline Other bias & Low risk & Intention to treat analysis \\
\hline
\end{tabular}

Kitzman 1997

\begin{tabular}{l|l}
\hline Methods & Randomised controlled trial. \\
\hline Participants & $\begin{array}{l}\text { Primiparous African-American women }<29 \text { weeks gestation, with at least two of the } \\
\text { following: unmarried, }<12 \text { years education, unemployed }\end{array}$ \\
\hline Interventions & $\begin{array}{l}\text { Intervention arm } 1: \text { Free transportation to pre-natal care visits. } \\
\text { Intervention arm } 2: \text { Intervention arm } 1+\text { developmental screening and referral services } \\
\text { for child at } 6,12 \text { and } 24 \text { months of age (this group acted as the control group for assessing } \\
\text { the effect of post-natal home visiting). } \\
\text { Intervention arm 3: Intervention arm } 2+\text { pre-natal home visits }+1 \text { hospital }+1 \text { home } \\
\text { post-partum visit } \\
\text { Intervention arm 4: Intervention arm } 3+26 \text { post-natal home visits from birth to } 2 \text { years } \\
\text { of age. programme. (This group acted as the intervention group for assessing the effect } \\
\text { of post-natal home visiting). } \\
\text { Home visits comprised (a) specific curriculum covering parental education regarding un- } \\
\text { derstanding infants communication signals, enhancing interest in playing with children } \\
\text { in ways that promote emotional and cognitive development and creating households that } \\
\text { are safer for children. Help also provided to mothers to clarify goals and solve problems } \\
\text { relating to completing education, finding work and planning future pregnancies. Home } \\
\text { visits provided by nurses }\end{array}$ \\
\hline
\end{tabular}

Outcomes

Total number of health care encounters ascertained from medical records, for injuries/ ingestions.

HOME inventory. 
Kitzman 1997 (Continued)

\begin{tabular}{ll}
\hline Notes & Selection bias: allocation by independent computer programme \\
Detection bias: outcome assessors blinded to treatment arm allocation. \\
Data from intervention arms 2 (control) and 4 (intervention) used in paper to evaluate \\
effect of home visits and has been used in meta-analyses. \\
Attrition bias: \\
At start of study: \\
Control arm $\mathrm{n}=515$ \\
Intervention arm $\mathrm{n}=228$ \\
At 24 months follow up; \\
Control arm $\mathrm{n}=481(93 \%)$ \\
Intervention arm $\mathrm{n}=216(95 \%)$ \\
\hline
\end{tabular}

Risk of bias

\begin{tabular}{|c|c|c|}
\hline Bias & Authors' judgement & Support for judgement \\
\hline $\begin{array}{l}\text { Random sequence generation (selection } \\
\text { bias) }\end{array}$ & Low risk & $\begin{array}{l}\text { Use of "computer program that randomized individual } \\
\text { women" }\end{array}$ \\
\hline Allocation concealment (selection bias) & Low risk & $\begin{array}{l}\text { Performed remotely to participants and study person- } \\
\text { nel. Allocation "procedure concealed the randomization } \\
\text { from individuals directly involved with participants" }\end{array}$ \\
\hline $\begin{array}{l}\text { Blinding of participants and personnel } \\
\text { (performance bias) } \\
\text { All outcomes }\end{array}$ & High risk & Not possible. \\
\hline $\begin{array}{l}\text { Blinding of outcome assessment (detection } \\
\text { bias) } \\
\text { All outcomes }\end{array}$ & Low risk & $\begin{array}{l}\text { "Interviews and abstractions of medical and social ser- } \\
\text { vice records were conducted by staff members who were } \\
\text { unaware of the women's treatment assignment" }\end{array}$ \\
\hline $\begin{array}{l}\text { Incomplete outcome data (attrition bias) } \\
\text { All outcomes }\end{array}$ & Low risk & Attrition rate of $6 \%$ \\
\hline Selective reporting (reporting bias) & Low risk & Reports all outcomes \\
\hline Other bias & Low risk & $\begin{array}{l}\text { Intention to treat analysis undertaken. Appears to be free } \\
\text { of other biases }\end{array}$ \\
\hline
\end{tabular}

Koniak-Griffin 2003

\begin{tabular}{l|l}
\hline Methods & Randomised controlled trial \\
\hline Participants & $\begin{array}{l}\text { Adolescents aged } 14 \text { to } 19 \text { years of age at } 26 \text { weeks gestation or less, having their first } \\
\text { child and planning to keep the infant }\end{array}$
\end{tabular}




\begin{tabular}{|c|c|c|}
\hline Interventions & \multicolumn{2}{|c|}{$\begin{array}{l}\text { Early Intervention Program (IEP) provided to young mothers through home visits by } \\
\text { public health nurses and designed to influence maternal and child health. Included a } \\
\text { maximum of } 17 \text { home visits: } 2 \text { prenatal and } 15 \text { postpartum, } 1.5 \text { to } 2 \text { hours each. The } \\
\text { mean number of visits prenatally was } 2.13(\mathrm{SD}=0.77) \text { and postnatally } 10.35 \text { ( } \mathrm{SD}=3.04) \\
\text { Control mothers received Traditional Public Health Nursing Care which consisted of } 1 \\
\text { home visit prenatally and } 1 \text { visit postnatally. The mean number of visits prenatally was } \\
1.02(\mathrm{SD}=0.26 \text { ) and postnatally } 1.09(\mathrm{SD}=0.42)\end{array}$} \\
\hline Outcomes & \multicolumn{2}{|c|}{$\begin{array}{l}\text { Emergency room visits for injury but not reported by treatment. group. Total HOME } \\
\text { scores. Data collected at intake, } 6 \text { weeks after the birth, and } 6,12,18 \text { and } 24 \text { months } \\
\text { postpartum for all outcomes except for HOME score which was assessed at } 12 \text { and } 24 \\
\text { months post partum }\end{array}$} \\
\hline Notes & \multicolumn{2}{|c|}{$\begin{array}{l}\text { Attrition bias: } \\
\text { Mothers enrolled: } \\
\text { Intervention arm (EIP) } n=56 \\
\text { Control arm (TPHNC) } n=45 \\
\text { No information on } 43 \text { drop outs (excluded from numbers above) } \\
\text { Data on SD for HOME scores received from a personal communication (15th April } \\
2012 \text { ) }\end{array}$} \\
\hline \multicolumn{3}{|l|}{ Risk of bias } \\
\hline Bias & Authors' judgement & Support for judgement \\
\hline $\begin{array}{l}\text { Random sequence generation (selection } \\
\text { bias) }\end{array}$ & Low risk & "Using a computer-based program" \\
\hline Allocation concealment (selection bias) & Unclear risk & Not reported \\
\hline $\begin{array}{l}\text { Blinding of participants and personnel } \\
\text { (performance bias) } \\
\text { All outcomes }\end{array}$ & High risk & Participants and nurses not blinded \\
\hline $\begin{array}{l}\text { Blinding of outcome assessment (detection } \\
\text { bias) } \\
\text { All outcomes }\end{array}$ & Low risk & $\begin{array}{l}\text { Interviews conducted by Public Health Nurses who were } \\
\text { not involved in the intervention and were blind to group } \\
\text { assignment }\end{array}$ \\
\hline $\begin{array}{l}\text { Incomplete outcome data (attrition bias) } \\
\text { All outcomes }\end{array}$ & High risk & $\begin{array}{l}\text { No data on } 43 \text { dropouts. Data only given on } 101 \text { who } \\
\text { took part }\end{array}$ \\
\hline Selective reporting (reporting bias) & High risk & Does not report all data for injuries or HOME scores \\
\hline Other bias & Low risk & Appears to be free of other biases \\
\hline
\end{tabular}


Methods

Participants
Partially randomised controlled trial.

Pregnant women, aged 18-35 years, income below poverty line, high school education or less, no significant illness in pregnancy, no history of psychiatric hospitalisation and normal delivery of full term infant discharged from hospital within 5 days with no major congenital defects

Group A: pre-natal home visit, plus post-natal hospital visit, plus 9 post-natal home visits from 6 weeks to 15 months of age. Home visits followed protocol consisting of counselling and advice relating to general caretaking (e.g. feeding, sleeping, clothing, bathing, accident prevention, encouragement to take part in well-child care), motherinfant interaction (e.g. encouragement of frequent reciprocal interaction), social status (reviewing mother's relationship with child's father, support systems and any areas of exceptional stress and concern) and child development (e.g. reviewing child's developmental competence and suggesting activities to promote child's capabilities). Home visits provided by psychology graduates.

Group B: Post-natal home visits as for group A (10 visits from 6 weeks to 15 months of age).

Group C: No home visits.

Outcomes

Cumulative accident rates obtained from maternal reports.

HOME inventory.

Notes

Selection bias: allocation to groups $\mathrm{B}$ and $\mathrm{C}$ by random assignment. Allocation to group A sequential following random assignment to groups $\mathrm{B}$ and $\mathrm{C}$

Detection bias: outcome assessors blinded to treatment arm allocation.

Risk of confounding: authors state no significant difference between treatment groups in terms of sex, parity, income, parental education, marital status, planned pregnancy, prenatal care, presence of father at delivery or use of private medical care

Attrition bias:

At start of study:

Group A n=35

Group B $\mathrm{n}=36$

Group C $n=44$

Follow up when child 18 months of age:

Group A=26 (74\%)

Group B=27 (75\%)

Group C=37 (84\%).

For the purposes of meta-analysis groups $\mathrm{A}$ and $\mathrm{B}$ were combined as the intervention group as had a parenting programme during the post-natal period. Group C was used as the control group

\section{Risk of bias}

\section{Bias}

Random sequence generation (selection Unclear risk bias)
Authors' judgement
Support for judgement

Not reported 
Larson 1980 (Continued)

\begin{tabular}{|c|c|c|}
\hline $\begin{array}{l}\text { Allocation to intervention/control (selec- } \\
\text { tion bias)(For non randomised and CBA } \\
\text { studies) }\end{array}$ & Unclear risk & Not reported \\
\hline Allocation concealment (selection bias) & Unclear risk & Not reported \\
\hline $\begin{array}{l}\text { Blinding of participants and personnel } \\
\text { (performance bias) } \\
\text { All outcomes }\end{array}$ & High risk & Not blinded \\
\hline $\begin{array}{l}\text { Blinding of outcome assessment (detection } \\
\text { bias) } \\
\text { All outcomes }\end{array}$ & Low risk & Home observers were blinded \\
\hline $\begin{array}{l}\text { Incomplete outcome data (attrition bias) } \\
\text { All outcomes }\end{array}$ & High risk & Attrition rate of $22 \%$ \\
\hline Selective reporting (reporting bias) & Low risk & Appears complete \\
\hline Other bias & Unclear risk & Intention to treat analysis not reported \\
\hline $\begin{array}{l}\text { Risk of bias due to confounding (For non } \\
\text { randomised and CBA studies) }\end{array}$ & Low risk & $\begin{array}{l}\text { There was an assessment of the distribution of } \\
\text { confounders between treatment arms and the } \\
\text { arms appear similar }\end{array}$ \\
\hline
\end{tabular}

Llewellyn 2003

\begin{tabular}{ll}
\hline Methods & Randomised controlled trial. \\
\hline Participants & $\begin{array}{l}\text { Parents with intellectual disability whose first language was English, who were the primary } \\
\text { carers of children under } 5 \text { years of age }\end{array}$ \\
\hline Interventions & $\begin{array}{l}\text { groups with } 3 \text { intervention phases: } \\
\text { Group } 1 \text { : Home Learning Programme comprising } 10 \text { lessons with accompanying book- } \\
\text { lets provided by parent educator at home covering understanding sickness and health, } \\
\text { when to call the doctor, how to take a child's temperature and check respiration, common } \\
\text { life threatening emergencies, home safety. HLP delivered in intervention phase } 1 . \\
\text { Group 2: Home visits to discuss everyday experiences of raising children without educa- } \\
\text { tional input, delivered in intervention phase 1. HLP delivered in intervention phase } 2 . \\
\text { Group 3: Usual care delivered in intervention phase 1. Mailed lesson booklets + telephone } \\
\text { contact with parent educators to check progress with reading booklets and implementing } \\
\text { information in booklets without any face-face education, delivered in intervention phase } \\
\text { 2. HLP delivered in intervention phase 3. } \\
\text { Group 4. Standard community services delivered in intervention phase } 1 . \text { HLP delivered } \\
\text { in intervention phase } 2\end{array}$
\end{tabular}

Parenting interventions for the prevention of unintentional injuries in childhood (Review) 


\section{Llewellyn 2003 (Continued)}

Outcomes
Number of home dangers identified; number of precautions identified to deal with home dangers; total number of precautions taken by parents to deal with home dangers observed using checklist

Selection bias: allocation by project manager using table of random numbers.

Detection bias: outcome assessors blinded to treatment group allocation.

Attrition bias:

At start of study:

$\mathrm{n}=57$ not specified by treatment arm

At 3 months follow up;

Group $1 \mathrm{n}=20$

Group $2 \mathrm{n}=11$

Group $3 \mathrm{n}=10$

Group $4 \mathrm{n}=4$

\section{Risk of bias}

\begin{tabular}{|c|c|c|}
\hline Bias & Authors' judgement & Support for judgement \\
\hline $\begin{array}{l}\text { Random sequence generation (selection } \\
\text { bias) }\end{array}$ & Low risk & "Table of random numbers" \\
\hline Allocation concealment (selection bias) & Unclear risk & Not reported \\
\hline $\begin{array}{l}\text { Blinding of participants and personnel } \\
\text { (performance bias) } \\
\text { All outcomes }\end{array}$ & High risk & Not blinded \\
\hline $\begin{array}{l}\text { Blinding of outcome assessment (detection } \\
\text { bias) } \\
\text { All outcomes }\end{array}$ & Low risk & $\begin{array}{l}\text { "Trained parents assessors who were blind to each par- } \\
\text { ent's group" }\end{array}$ \\
\hline $\begin{array}{l}\text { Incomplete outcome data (attrition bias) } \\
\text { All outcomes }\end{array}$ & High risk & Attrition rate of $29 \%$ \\
\hline Selective reporting (reporting bias) & Unclear risk & Does not appear so \\
\hline Other bias & Unclear risk & $\begin{array}{l}\text { Intention to treat analysis not reported. Does not appear } \\
\text { to be other biases }\end{array}$ \\
\hline
\end{tabular}

Minkovitz 2003 (a)

\begin{tabular}{l|l}
\hline Methods & Randomised controlled trial \\
\hline Participants & $\begin{array}{l}\text { Families with newborns up to } 4 \text { weeks of age. Families were excluded if the newborn was } \\
\text { to be adopted, fostered or was too ill to make an office visit in the first } 4 \text { weeks of life, } \\
\text { if mother did not speak English or Spanish or the family intended to leave the practice } \\
\text { within } 6 \text { months }\end{array}$
\end{tabular}


Minkovitz 2003 (a) (Continued)

\begin{tabular}{|c|c|}
\hline Interventions & $\begin{array}{l}\text { Intervention arm: "Healthy Steps Programme" for the first } 3 \text { years of life which included } \\
\text { extended well-child office visits (average } 11 \text { in first } 2.5 \text { years of life) to address questions } \\
\text { and concerns about child development and behaviour and promotion of positive parent- } \\
\text { child interactions, home vitis (average }<2 \text { in first } 2.5 \text { years of life) to inform parents about } \\
\text { fostering intellectual and emotional development, telephone line to answer questions } \\
\text { about child development, parent groups to offer social support and interactive learning } \\
\text { sessions and practice in problem solving, written information for parents emphasising } \\
\text { importance of prevention and health promotion. Programme delivered by paediatricians } \\
\text { and Healthy Steps Specialists (nurses, nurse practitioners, social workers and early child- } \\
\text { hood educators). Programme planned, implemented and process evaluated using the } \\
\text { PRECEDE/PROCEED model. } \\
\text { Control arm: conventional paediatric care. }\end{array}$ \\
\hline Outcomes & $\begin{array}{l}\text { Maternal reports of emergency department use in last year for injury-related causes. } \\
\text { Safety practices including lowered temperature on water heater, use of socket covers, } \\
\text { use of cabinet safety catches, functional smoke detectors, placed stickers on bottles of } \\
\text { poisonous substances, knew number to call if child swallowed something harmful }\end{array}$ \\
\hline Notes & $\begin{array}{l}\text { These are the results from the randomisation sites from the Minkovitz } 2003 \text { study } \\
\text { Selection bias: allocation using computer generated assignment sequence and sealed } \\
\text { opaque envelopes. Detection bias: unclear if outcome assessors blinded to treatment } \\
\text { group allocation. } \\
\text { Attrition bias: } \\
\text { At start of study (randomised part) } \\
\text { Intervention arm } n=1133 \\
\text { control arm } n=1102 \\
\text { At } 30-33 \text { months follow up (randomised part ): } \\
\text { Intervention arm } n=832(73 \%) \\
\text { Control arm } n=761(69 \%)\end{array}$ \\
\hline
\end{tabular}

Risk of bias

\begin{tabular}{l|l|l}
\hline Bias & Authors' judgement & Support for judgement \\
\hline $\begin{array}{l}\text { Random sequence generation (selection } \\
\text { bias) }\end{array}$ & Low risk & “Computer-generated assignment" \\
\hline $\begin{array}{l}\text { Allocation concealment (selection bias) } \\
\text { Blinding of participants and personnel } \\
\text { (performance bias) } \\
\text { All outcomes }\end{array}$ & High risk risk & "Concealed in sealed envelopes" \\
\hline $\begin{array}{l}\text { Blinding of outcome assessment (detection } \\
\text { bias) } \\
\text { All outcomes }\end{array}$ & Unclear risk & Not reported \\
\hline $\begin{array}{l}\text { Incomplete outcome data (attrition bias) } \\
\text { All outcomes }\end{array}$ & High risk & Attrition rate of 29\% \\
\hline $\begin{array}{l}\text { Parenting interventions for the prevention of unintentional injuries in childhood (Review) } \\
\text { Copyright } \odot \text { 2013 The Cochrane Collaboration. Published by John Wiley \& Sons, Ltd. }\end{array}$
\end{tabular}


Minkovitz 2003 (a) (Continued)

\begin{tabular}{|c|c|c|}
\hline Selective reporting (reporting bias) & Low risk & Reporting appears complete \\
\hline Other bias & Low risk & $\begin{array}{l}\text { Intention to treat analysis undertaken. Does not appear } \\
\text { to be other biases }\end{array}$ \\
\hline
\end{tabular}

Minkovitz 2003 (b)

Methods

Participants

Outcomes

Notes

Risk of bias

Bias
Controlled before and after study (cluster allocated).

Families with newborns up to 4 weeks of age. Families were excluded if the newborn was to be adopted, fostered or was too ill to make an office visit in the first 4 weeks of life, if mother did not speak English or Spanish or the family intended to leave the practice within 6 months

Intervention arm: "Healthy Steps Programme" for the first 3 years of life which included extended well-child office visits (average 11 in first 2.5 years of life) to address questions and concerns about child development and behaviour and promotion of positive parentchild interactions, home vitis (average $<2$ in first 2.5 years of life) to inform parents about fostering intellectual and emotional development, telephone line to answer questions about child development, parent groups to offer social support and interactive learning sessions and practice in problem solving, written information for parents emphasising importance of prevention and health promotion. Programme delivered by paediatricians and Healthy Steps Specialists (nurses, nurse practitioners, social workers and early childhood educators). Programme planned, implemented and process evaluated using the PRECEDE/PROCEED model.

Control arm: conventional paediatric care.

Maternal reports of emergency department use in last year for injury-related causes.

Safety practices including lowered temperature on water heater, use of socket covers, use of cabinet safety catches, functional smoke detectors, placed stickers on bottles of poisonous substances, knew number to call if child swallowed something harmful

These are the results from the CBA sites reported in the same paper as for Minkovitz 2003 (a)

Attrition bias:

At start of study

Intervention arm $\mathrm{n}=1830$

Control arm $\mathrm{n}=1500$

At 30-33 months follow up

Intervention arm $\mathrm{n}=1189(65 \%)$

Control arm n=955 (64\%) 
Minkovitz 2003 (b) (Continued)

Allocation to intervention/control (selec- Unclear risk tion bias)(For non randomised and CBA

studies)
Does not describe how sites were chosen

Blinding of participants and personnel High risk

Not blinded

(performance bias)

All outcomes

Blinding of outcome assessment (detection Unclear risk

Not reported

bias)

All outcomes

Incomplete outcome data (attrition bias) High risk

Attrition rate of $64 \%$

All outcomes

\begin{tabular}{l|ll}
\hline Selective reporting (reporting bias) & Low risk & Reporting appears complete \\
\hline Other bias & Low risk & $\begin{array}{l}\text { Intention to treat analysis undertaken. } \\
\text { Does not appear to be other biases }\end{array}$ \\
\hline
\end{tabular}

Risk of bias due to confounding (For non High risk randomised and CBA studies)

There was an assessment of the distribution of confounders between treatment arms and arms differ on a number of potential confounding variables

Olds 1986

\begin{tabular}{ll}
\hline Methods & Randomised controlled trial. \\
\hline Participants & $\begin{array}{l}\text { Primiparous women }<30 \text { weeks gestation, and at least one of the following: } \\
\text { aged }<19 \text { years, single parents, low socio-economic status. }\end{array}$ \\
\hline Interventions & $\begin{array}{l}\text { Intervention arm } 1: \text { usual care }+ \text { free transportation to pre-natal and well child visits. } \\
\text { Intervention arm } 2: \text { Intervention arm } 1+9 \text { home visits during pregnancy. }\end{array}$ \\
$\begin{array}{l}\text { Intervention arm } 3: \text { Intervention arm } 2+\text { post-natal home visits weekly from birth to } \\
6 \text { weeks of age; } 2 \text { weekly visits from } 6 \text { weeks to } 4 \text { months of age; } 3 \text { weekly from } 4 \text { to }\end{array}$ \\
$\begin{array}{l}14 \text { months of age; } 4 \text { weekly from } 14 \text { to } 20 \text { months of age and } 6 \text { weekly from } 20 \text { to } 24 \\
\text { months of age. }\end{array}$ \\
$\begin{array}{l}\text { Home visits comprised (a) detailed } \\
\text { curriculum covering parental education regarding infant development aimed at improv- } \\
\text { ing parental behaviour that affects the child's well-being (e.g. understanding infants tem- } \\
\text { perament, crying behaviour, need for responsive care-giving, physical health care needs, } \\
\text { managing common health problems) } \\
\text { (b) enhancing informal support through encouraging family and friends to help with } \\
\text { household responsibilities and child care, and } \\
\text { (c) linking family with community health and social care services (e.g. well-child care, } \\
\text { vocational training programmes, mental health counselling, legal aid, nutritional sup- } \\
\text { plementation programmes etc).Home visits provided by nurses. }\end{array}$
\end{tabular}

Parenting interventions for the prevention of unintentional injuries in childhood (Review) 
Olds 1986 (Continued)

Control arm: usual care, no transportation to pre-natal or well-child visits, no home visits

Outcomes

Emergency department visits for injuries or ingestions.

Home hazards assessed by observers at 34 and 46 months (included chipped or flaking paint, sharp objects, danger of burns, dangerously placed objects posing a risk of falls).

Self-reported presence and accessibility of poisonous substances and use of child car restraints

Notes

Selection bias: allocation using deck of cards, drawn by participants

Detection bias: outcome assessors blinded to treatment arm allocation

During the study the control arm and intervention arm 1 were combined to form the control arm when no differences were found in use of routine pre-natal and well child care. Data from intervention arm 3 and the combined control arm used in paper to evaluate effect of home visits and has been used in the meta-analyses.

Attrition bias:

At start of study:

Control arm $\mathrm{n}=184$

Intervention arm $\mathrm{n}=116$

At 1 year follow up:

Control arm $\mathrm{n}=136(74 \%)$

Intervention arm $\mathrm{n}=87(75 \%)$.

At 2 years follow up:

Control arm $\mathrm{n}=121(66 \%)$

Intervention arm $\mathrm{n}=75(65 \%)$

Later follow up described in Olds 1994:

Assessed at 25 to 50 months

At 25-50 months follow up:

Control arm $\mathrm{n}=137(74 \%)$

Intervention arm $\mathrm{n}=84(72 \%)$

Risk of bias

Bias

Authors' judgement

Support for judgement

Random sequence generation (selection High risk Unclear

bias)

Allocation concealment (selection bias) High risk

"Women drew their treatment assignments from a deck of cards", some deviations

Blinding of participants and personnel High risk

Unable to blind participants and study personnel (performance bias)

All outcomes

Blinding of outcome assessment (detection Low risk bias)

All outcomes

"Except in a small number of cases in which participating women inadvertently disclosed their treatment assignments, all interview and medical record data were collected by staff members who were unaware of the 
Olds 1986 (Continued)

families' treatment assignments"

\begin{tabular}{l|ll}
\hline $\begin{array}{l}\text { Incomplete outcome data (attrition bias) } \\
\text { All outcomes }\end{array}$ & High risk & "Attrition varied from 15\% to 21\%" \\
\hline Selective reporting (reporting bias) & High risk & Data not reported \\
\hline Other bias & Low risk & $\begin{array}{l}\text { Intention to treat analyses not reported. Appears to be } \\
\text { free of other biases }\end{array}$ \\
\hline
\end{tabular}

St Pierre 1999

\begin{tabular}{ll}
\hline Methods & Randomised controlled trial \\
\hline Participants & $\begin{array}{l}\text { Families with incomes below the federal poverty level and with unborn children or } \\
\text { children under age one year }\end{array}$ \\
\hline Interventions & $\begin{array}{l}\text { The Comprehensive Child Development Programme was not conceived as a home vis- } \\
\text { iting program but it used home visits as the primary means for delivering case manage- } \\
\text { ment and early childhood education. Short and long term program effects were expected } \\
\text { for children and parents through the delivery of educational, health and social services } \\
\text { tailored to each family. Case managers were expected to conduct home visits to each } \\
\text { family at least twice per month and to last for } 1 \text { hour. In practice visits were conducted } \\
3 \text { to } 4 \text { times a month and lasted } 30 \text { to } 90 \text { minutes depending on the family's needs. } \\
\text { The model called for services to be provided to all families continuously from the time } \\
\text { the family entered the program, before the child was } 1 \text { year old, until the child entered } \\
\text { school }\end{array}$ \\
\hline
\end{tabular}

Outcomes

Data was collected mainly at the child's 2 nd, 3rd, 4th and 5th birthday with some data collected at 18 and 30 months of age

HOME score assessed at 18 or 24 months of age and at 36 months, however, results only given for 4 year follow up

$\begin{array}{ll}\text { Notes } & \text { Attrition bias: } \\ & \text { At the start of the study: } \\ & \text { Intervention arm } \mathrm{n}=2213 \\ & \text { Control arm } \mathrm{n}=2197 \\ & \text { For HOME scores at } 4 \text { years follow-up } \\ \text { Intervention arm } \mathrm{n}=1321=59.7 \% \\ \text { Control arm } \mathrm{n}=1423=64.8 \% \\ \text { See also paper by Goodson et al } 2000\end{array}$

\section{Risk of bias}

\begin{tabular}{lll} 
Bias & Authors' judgement & Support for judgement \\
\hline $\begin{array}{l}\text { Random sequence generation (selection } \\
\text { bias) }\end{array}$ & Unclear risk & $\begin{array}{l}\text { "Each site implemented a random assignment proce- } \\
\text { dure". "Most sites used stratified random assignment, us- }\end{array}$
\end{tabular}


St Pierre 1999 (Continued)

ing stratifiers such as ethnicity, age of mother, and service sites"

\begin{tabular}{|c|c|c|}
\hline Allocation concealment (selection bias) & Unclear risk & Not reported \\
\hline $\begin{array}{l}\text { Blinding of participants and personnel } \\
\text { (performance bias) } \\
\text { All outcomes }\end{array}$ & High risk & Not possible \\
\hline $\begin{array}{l}\text { Blinding of outcome assessment (detection } \\
\text { bias) } \\
\text { All outcomes }\end{array}$ & Unclear risk & $\begin{array}{l}\text { Child testers were blind to the family's group assignment } \\
\text { at the start of study }\end{array}$ \\
\hline $\begin{array}{l}\text { Incomplete outcome data (attrition bias) } \\
\text { All outcomes }\end{array}$ & High risk & $\begin{array}{l}\text { At the five year assessment } 74 \% \text { of intervention and } 78 \% \\
\text { of control families participated in the evaluation }\end{array}$ \\
\hline Selective reporting (reporting bias) & High risk & Early data not reported \\
\hline Other bias & Low risk & Does not appear to be other biases \\
\hline
\end{tabular}

Characteristics of excluded studies [ordered by study ID]

\begin{tabular}{|c|c|}
\hline Study & Reason for exclusion \\
\hline Akinbami 2001 & Does not report study design of interest: no control group \\
\hline Babul 2007 & Does not report intervention of interest \\
\hline Baron-Epel 2006 & Does not report study design of interest: no control group \\
\hline Beirens 2006 & Paper unobtainable \\
\hline Bond 2006 & Does not report study design of interest: no control group \\
\hline Conroy 1994 & Does not report study design of interest: no control group \\
\hline Culp 1998 & Does not report study design of interest: no control group \\
\hline Cupples 2011 & Does not report intervention of interest \\
\hline Dawson 1989 & Does not report intervention of interest \\
\hline Donnellan 1981 & Does not report outcomes of interest \\
\hline Ertem 2006 & Does not report intervention of interest \\
\hline
\end{tabular}




\section{(Continued)}

\begin{tabular}{|c|c|}
\hline Feldman 2004 & Does not report study design of interest: no control group \\
\hline Fitzpatrick 1997 & Does not report study design of interest: a prospective study \\
\hline Gershater-Molko 2002 & Does not report study design of interest: no control group \\
\hline Gershater-Molko 2003 & Does not report study design of interest: no control group \\
\hline Gray 1979 & Does not report intervention of interest \\
\hline Guyer 2000 & Does not report outcomes of interest \\
\hline Hedges 2005 & Does not report outcomes of interest \\
\hline Hemmo-Lotom 2006 & Paper unobtainable \\
\hline Huxley 1993 & Does not report study design of interest: retrospective control group \\
\hline Jackson 2009 & Does not report study design of interest: developing, as opposed to testing, an intervention \\
\hline Johnson 2009 & Does not report outcomes of interest \\
\hline Jordaan 2006 & Does not report study design of interest: developing a measurement tool \\
\hline Jouriles 2010 & Does not report outcomes of interest. \\
\hline Kluger 2000 & Does not report study design of interest: not testing an intervention \\
\hline Lealman 1983 & Does not report intervention of interest \\
\hline McAuley 2004 & Does not report intervention of interest \\
\hline Odendall 2009 & IDoes not report intervention of interest \\
\hline Powell 2004 & Does not report outcomes of interest \\
\hline Quraishi 2005 & Does not report study design of interest: not testing an intervention \\
\hline Sharma 2006 & Paper unobtainable \\
\hline Smith 1984 & Does not report outcomes of interest \\
\hline Subhi 2009 & Does not report study design of interest: no control group \\
\hline Swart 2008 & Does not report intervention of interest \\
\hline
\end{tabular}


(Continued)

Taban 2001

Does not report study design of interest: no control group

Trudeau 2010

Does not report intervention of interest

Tsoumakas 2009

Does not report study design of interest: a descriptive study

Van As, 2006

Paper unobtainable

Parenting interventions for the prevention of unintentional injuries in childhood (Review)

Copyright @ 2013 The Cochrane Collaboration. Published by John Wiley \& Sons, Ltd. 
DATA ANDANALYSES

Comparison 1. Intervention versus Control (n/ $\mathrm{N}$ in clustered studies adjusted for clustering)

\begin{tabular}{lcccc} 
Outcome or subgroup title & $\begin{array}{c}\text { No. of } \\
\text { studies }\end{array}$ & $\begin{array}{c}\text { No. of } \\
\text { participants }\end{array}$ & Statistical method & Effect size \\
\hline $\begin{array}{l}\text { 1 Medically attended or } \\
\text { self-reported injuries - RCTs } \\
\text { only }\end{array}$ & 10 & 5074 & Risk Ratio (M-H, Random, 95\% CI) & $0.83[0.73,0.94]$ \\
\hline
\end{tabular}

Comparison 2. Total HOME scores

\begin{tabular}{lccccc} 
Outcome or subgroup title & $\begin{array}{c}\text { No. of } \\
\text { studies }\end{array}$ & $\begin{array}{c}\text { No. of } \\
\text { participants }\end{array}$ & Statistical method & Effect size \\
\hline 1 Total HOME scores & 3 & 368 & Mean Difference (IV, Random, 95\% CI) & $0.57[-0.59,1.72]$ \\
\hline
\end{tabular}


Analysis I.I. Comparison I Intervention versus Control ( $\mathrm{n} / \mathrm{N}$ in clustered studies adjusted for clustering), Outcome I Medically attended or self-reported injuries - RCTs only.

Review: Parenting interventions for the prevention of unintentional injuries in childhood

Comparison: I Intervention versus Control (n/ $\mathrm{N}$ in clustered studies adjusted for clustering)

Outcome: I Medically attended or self-reported injuries - RCTs only

\begin{tabular}{|c|c|c|c|c|c|}
\hline Study or subgroup & Treatment & $\begin{array}{r}\text { Control } \\
n / N\end{array}$ & $\begin{array}{c}\text { Risk Ratio } \\
\text { M- } \\
\text { H,Random,95\% } \\
\mathrm{Cl}\end{array}$ & Weight & $\begin{array}{c}\text { Risk Ratio } \\
\text { M- } \\
\text { H,Random,95\% } \\
\text { Cl }\end{array}$ \\
\hline Armstrong 2000 & $7 / 80$ & $16 / 80$ & & $2.3 \%$ & $0.44[0.19,1.01]$ \\
\hline Caldera 2007 & $38 / 131$ & $44 / 137$ & $\rightarrow$ & $11.7 \%$ & $0.90[0.63,1.30]$ \\
\hline Duggan 1999 & $68 / 309$ & $54 / 225$ & & $15.4 \%$ & $0.92[0.67,1.25]$ \\
\hline Fergusson 2005 & $32 / 184$ & $54 / 207$ & $\rightarrow$ & $10.1 \%$ & $0.67[0.45,0.98]$ \\
\hline Gutelius 1977 & $5 / 44$ & $9 / 45$ & & $1.5 \%$ & $0.57[0.21,1.56]$ \\
\hline IHDP 1990 & $17 / 345$ & $26 / 551$ & 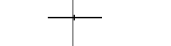 & $4.4 \%$ & $1.04[0.58,1.90]$ \\
\hline Johnson 1993 & $3 / 127$ & $8 / 105$ & & $0.9 \%$ & $0.31[0.08,1.14]$ \\
\hline Kitzman 1997 & $75 / 216$ & $207 / 481$ & - & $32.8 \%$ & $0.81[0.65,1.00]$ \\
\hline Minkovitz 2003 (a) & $77 / 832$ & $69 / 761$ & $\rightarrow$ & $15.8 \%$ & $1.02[0.75,1.39]$ \\
\hline Olds 1986 & $15 / 82$ & $31 / 132$ & $\rightarrow$ & $5.1 \%$ & $0.78[0.45,1.35]$ \\
\hline
\end{tabular}

Total (95\% CI)

2350

2724

$100.0 \%$

$0.83[0.73,0.94]$

Total events: 337 (Treatment), 518 (Control)

Heterogeneity: $\mathrm{Tau}^{2}=0.00 ; \mathrm{Ch}^{2}=9.23, \mathrm{df}=9(\mathrm{P}=0.42) ; \mathrm{I}^{2}=2 \%$

Test for overall effect: $Z=2.85(P=0.0044)$

Test for subgroup differences: Not applicable 


\section{Analysis 2.I. Comparison 2 Total HOME scores, Outcome I Total HOME scores.}

Review: Parenting interventions for the prevention of unintentional injuries in childhood

Comparison: 2 Total HOME scores

Outcome: I Total HOME scores

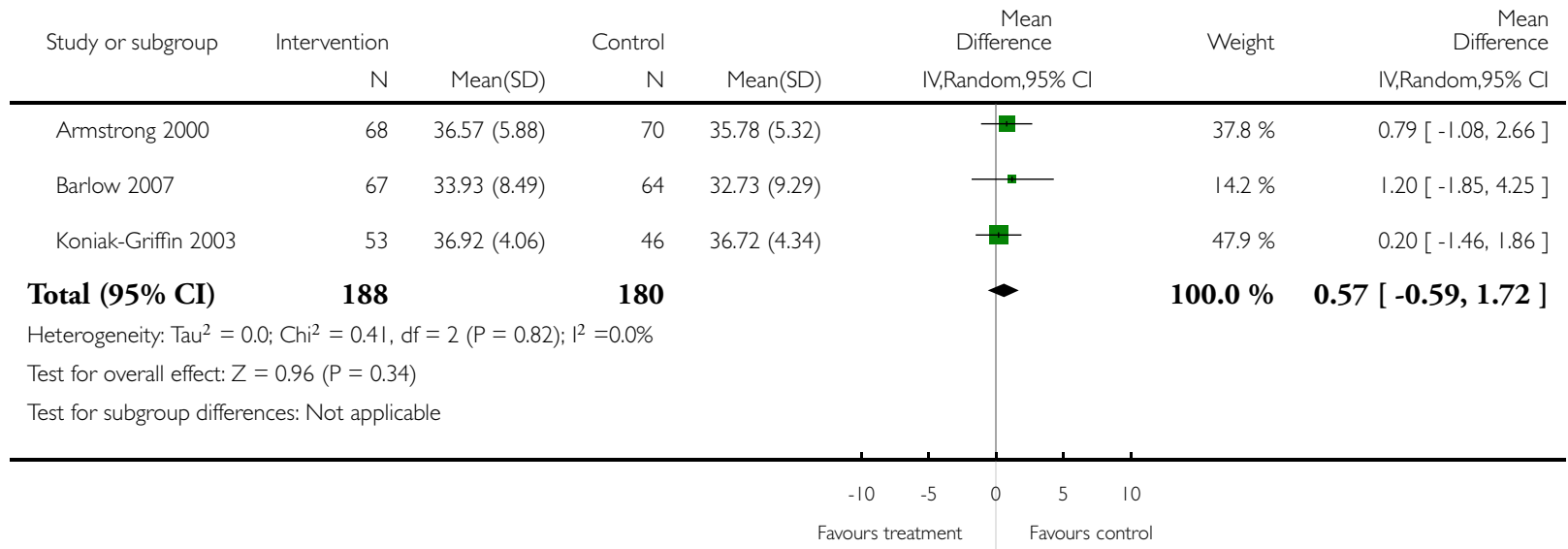

\section{ADDITIONAL TABLES}

Table 1. Summary of included studies: participant and intervention characteristics

\begin{tabular}{|c|c|c|c|c|c|c|c|c|c|}
\hline Study & $\begin{array}{l}\text { First au- } \\
\text { thor, year } \\
\text { First au- } \\
\text { thor, year } \\
\text { (second } \\
\text { paper) } \\
\text { Study de- } \\
\text { sign }\end{array}$ & $\begin{array}{l}\text { Study } \\
\text { popula- } \\
\text { tion }\end{array}$ & $\begin{array}{l}\text { Age of } \\
\text { child } \\
\text { at } \\
\text { start } \\
\text { of } \\
\text { pro- } \\
\text { gramme }\end{array}$ & $\begin{array}{l}\text { Length of } \\
\text { pro- } \\
\text { gramme } \\
\text { (months) }\end{array}$ & $\begin{array}{l}\text { Planned } \\
\text { total con- } \\
\text { tacts and } \\
\text { plan of } \\
\text { contacts }\end{array}$ & $\begin{array}{l}\text { Actual } \\
\text { total visits }\end{array}$ & $\begin{array}{l}\text { Delivery } \\
\text { setting }\end{array}$ & $\begin{array}{l}\text { Delivery } \\
\text { mode }\end{array}$ & Outcomes \\
\hline 1 & $\begin{array}{l}\text { Armstrong } \\
2000 \\
\text { Fraser } 2000 \\
\text { RCT }\end{array}$ & $\begin{array}{l}\text { EI- } \\
\text { THER one } \\
\text { of : physical } \\
\text { domestic } \\
\text { violence; } \\
\text { childhood } \\
\text { abuse of ei- } \\
\text { ther parent; } \\
\text { sole parent- } \\
\text { hood; } \\
\text { ambiva- }\end{array}$ & Birth & 6 & $\begin{array}{l}\text { approx } 12 \\
\text { (weekly for } \\
6 \text { weeks, } \\
\text { fortnightly } \\
\text { until } 3 \\
\text { months, } \\
\text { monthly } \\
\text { until } 6 \\
\text { months) }\end{array}$ & $6-13$ & home & individual & $\begin{array}{l}\text { Injuries } \\
\text { HOME } \\
\text { score }\end{array}$ \\
\hline
\end{tabular}




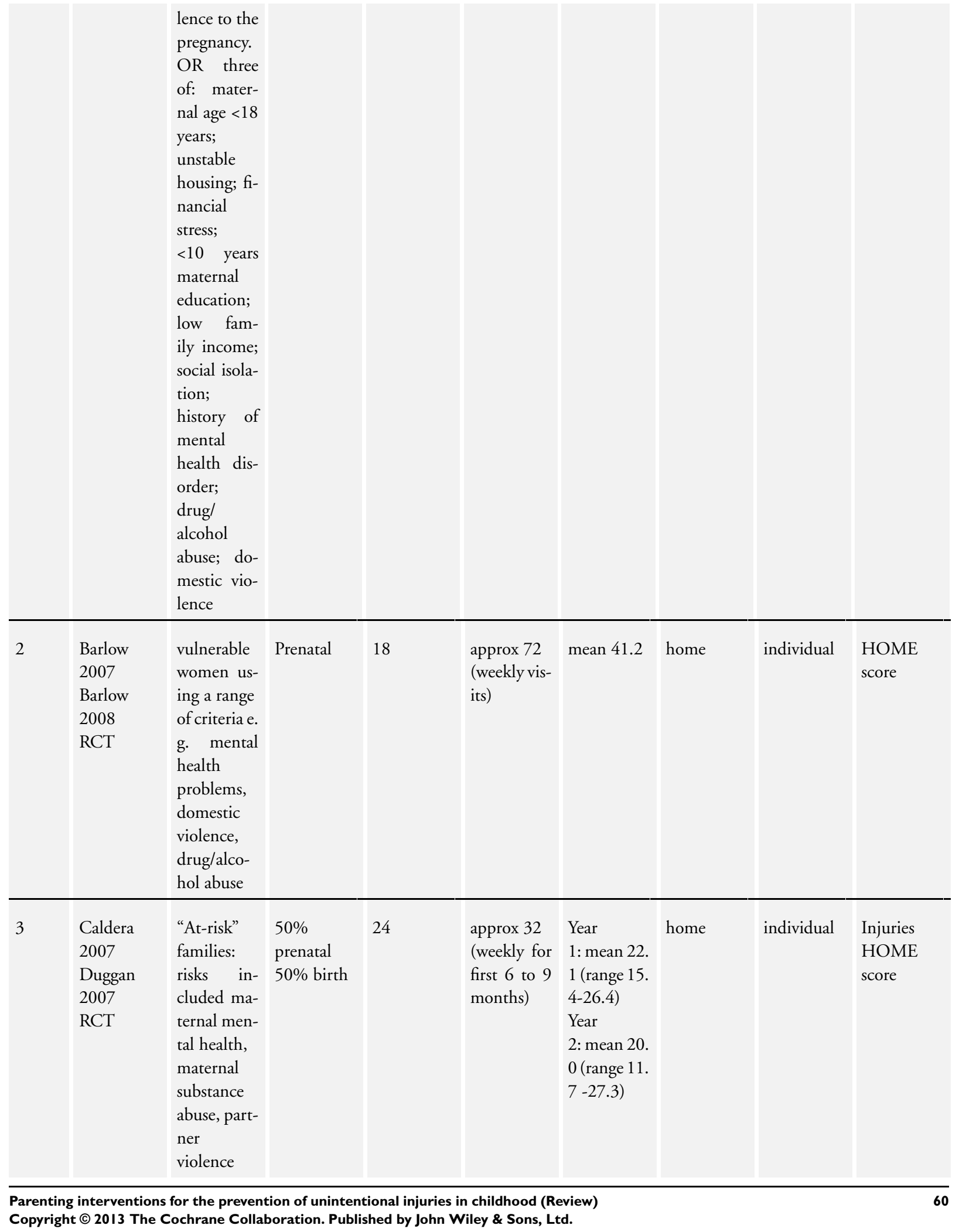


Table 1. Summary of included studies: participant and intervention characteristics (Continued)

\begin{tabular}{|c|c|c|c|c|c|c|c|c|c|}
\hline 4 & $\begin{array}{l}\text { Culp } 2007 \\
\text { cluster non } \\
\text { RCT }\end{array}$ & $\begin{array}{l}\text { first time } \\
\text { mothers } \\
\text { living in ru- } \\
\text { ral } \\
\text { commu- } \\
\text { nity }\end{array}$ & Prenatal & 15 & $\begin{array}{l}\text { approx } 40 \\
\text { (weekly in } \\
1 \text { st month, } \\
\text { fortnightly } \\
\text { for remain- } \\
\text { der of preg- } \\
\text { nancy, } \\
\text { weekly for } \\
1 \text { st } 3 \\
\text { months } \\
\text { postpar- } \\
\text { tum, fort- } \\
\text { nightly } \\
\text { from } \\
3 \\
12 \text { months } \\
\text { postpar- } \\
\text { tum }\end{array}$ & $\begin{array}{l}\text { mean } 10.9 \\
\text { prenatal } \\
\text { mean } 20.7 \\
0-12 \\
\text { months }\end{array}$ & home & individual & $\begin{array}{l}\text { Injuries } \\
\text { Home } \\
\text { safety* }\end{array}$ \\
\hline 5 & $\begin{array}{l}\text { Duggan } \\
1999 \\
\text { Duggan } \\
2004 \\
\text { RCT }\end{array}$ & $\begin{array}{l}\text { families } \\
\text { classified as } \\
\text { at } \\
\text { risk of child } \\
\text { abuse and } \\
\text { neglect. }\end{array}$ & $<1$ month & 24 & $\begin{array}{l}\text { approx } 45 \\
\text { (weekly vis- } \\
\text { its } \\
\text { decreas- } \\
\text { ing to quar- } \\
\text { terly) }\end{array}$ & $\begin{array}{l}\text { mean } 22 \\
\text { (in year } 1 \text { ) }\end{array}$ & home & individual & $\begin{array}{l}\text { Injuries } \\
\text { HOME } \\
\text { score }\end{array}$ \\
\hline 6 & $\begin{array}{l}\text { Emond } \\
2002 \\
\text { cluster } \\
\text { CBA }\end{array}$ & $\begin{array}{l}\text { first time } \\
\text { parents } \\
\text { from de- } \\
\text { prived areas }\end{array}$ & Prenatal & 11 & $\begin{array}{l}\text { approx } 8 \\
\text { (antenatal, } \\
\text { birth, } \\
3 \quad \text { weeks } \\
\text { postnatal } \\
\text { then every } \\
5 \text { weeks } \\
\text { until } 8 \\
\text { months) }\end{array}$ & $\begin{array}{l}\text { not } \\
\text { reported }\end{array}$ & home & individual & $\begin{array}{l}\text { Injuries } \\
\text { Home } \\
\text { safety* }\end{array}$ \\
\hline 7 & $\begin{array}{l}\text { Feldman } \\
1992 \\
\text { RCT }\end{array}$ & $\begin{array}{l}\text { mentally } \\
\text { retarded } \\
\text { mothers }\end{array}$ & $\begin{array}{l}1-23 \\
\text { months }\end{array}$ & 2 & $\begin{array}{l}\text { as many as } \\
\text { necessary } \\
\text { for mother } \\
\text { to learn } \\
\text { skills } \\
\text { (weekly) }\end{array}$ & $\begin{array}{l}\text { mean } 7.7 \\
\text { (range } 2 \text { - } \\
29 \text { ) }\end{array}$ & home & individual & $\begin{array}{l}\text { Home } \\
\text { safety* }\end{array}$ \\
\hline 8 & $\begin{array}{l}\text { Fergusson } \\
2005 \\
\text { RCT }\end{array}$ & $\begin{array}{l}2 \text { or more } \\
\text { of the fol- } \\
\text { lowing risk } \\
\text { factors: } \\
\text { age of par- } \\
\text { ents, }\end{array}$ & $<3$ months & 36 & $\begin{array}{l}\text { not } \\
\text { reported }\end{array}$ & $\begin{array}{l}\text { not } \\
\text { reported }\end{array}$ & home & individual & Injuries \\
\hline
\end{tabular}




\begin{tabular}{|c|c|c|c|c|c|c|c|c|c|}
\hline & & $\begin{array}{l}\text { social sup- } \\
\text { port, } \\
\text { planning of } \\
\text { pregnancy, } \\
\text { parental } \\
\text { substance } \\
\text { abuse, } \\
\text { financial } \\
\text { situa- } \\
\text { tion, family } \\
\text { violence }\end{array}$ & & & & & & & \\
\hline 9 & $\begin{array}{l}\text { Gutelius } \\
1977 \\
\text { RCT }\end{array}$ & $\begin{array}{l}\text { primigravi- } \\
\text { das, } \\
\text { unmarried, } \\
\text { women } \\
\text { aged 15-19 } \\
\text { years, } \\
\text { moth- } \\
\text { ers to black } \\
\text { babies, } \\
\text { from de- } \\
\text { prived areas }\end{array}$ & Prenatal & 36 & $\begin{array}{l}\text { approx } 64 \\
\text { routine vis- } \\
\text { its } \\
\text { (at least 9, } 6 \\
\text { and } 4 \text { in } \\
\text { years } 1,2 \\
\text { and } 3 \text { re- } \\
\text { spectively); } \\
\text { cog- } \\
\text { nitive stim- } \\
\text { ulation vis- } \\
\text { its } \\
\text { (at least } 18 \text {, } \\
12 \text { and } 8 \text { in } \\
\text { years } 1 \text {, } 2 \\
\text { and } 3 \text { re- } \\
\text { spectively) } \\
\text { group ses- } \\
\text { sions (16) }\end{array}$ & at least 64 & $\begin{array}{l}\text { home and } \\
\text { elsewhere }\end{array}$ & $\begin{array}{l}\text { individual } \\
\text { and group }\end{array}$ & Injuries \\
\hline 10 & $\begin{array}{l}\text { Hardy } \\
1989 \\
\text { quasi RCT }\end{array}$ & $\begin{array}{l}\text { inner city } \\
\text { mothers of } \\
\text { black ba- } \\
\text { bies, aged } \\
18 \text { years + }\end{array}$ & $\begin{array}{l}\text { shortly af- } \\
\text { ter birth } \\
(<10 \text { days } \\
\text { old })\end{array}$ & 24 & $\begin{array}{l}\text { approx } 10 \\
\text { (first at } 7 \text { - } \\
10 \text { days } \\
\text { then } 2-3 \\
\text { weeks prior } \\
\text { to well } \\
\text { child clinic } \\
\text { appoint- } \\
\text { ments at } 2 \text {, } \\
4,6,9,12 \text {, } \\
15,18,21 \text {, } \\
24 \text { months) }\end{array}$ & $\begin{array}{l}\text { not } \\
\text { reported }\end{array}$ & home & individual & Injuries \\
\hline 11 & $\begin{array}{l}\text { IHDP } \\
1990 \\
\text { RCT }\end{array}$ & $\begin{array}{l}\text { mothers } \\
\text { of low birth } \\
\text { weight ba- } \\
\text { bies }\end{array}$ & Birth & 36 & $\begin{array}{l}\text { approx } 116 \\
\text { (weekly } \\
\text { year 1, } \\
\text { fortnightly }\end{array}$ & $\begin{array}{l}\text { not } \\
\text { reported }\end{array}$ & $\begin{array}{l}\text { home and } \\
\text { elsewhere }\end{array}$ & $\begin{array}{l}\text { individual } \\
\text { and group }\end{array}$ & Injuries \\
\hline
\end{tabular}


Table 1. Summary of included studies: participant and intervention characteristics

\begin{tabular}{|c|c|c|c|c|c|c|c|c|c|}
\hline & & & & & $\begin{array}{l}\text { years } 2 \& 3 \text {, } \\
\text { bimonthly } \\
\text { group } \\
\text { meet- } \\
\text { ings years } 2 \\
\& 3 \text { ) }\end{array}$ & & & & \\
\hline 12 & $\begin{array}{l}\text { Johnson } \\
1993 \\
\text { Johnson } \\
2000 \\
\text { RCT }\end{array}$ & $\begin{array}{l}\text { first } \\
\text { time moth- } \\
\text { ers living in } \\
\text { deprived } \\
\text { areas }\end{array}$ & Birth & 12 & $\begin{array}{l}\text { approx } 14 \\
\text { (Once } \\
\text { a month for } \\
\text { first year + } \\
\text { birth and } 6 \\
\text { week visit) }\end{array}$ & $\begin{array}{l}\text { Of } 127 \\
\text { mothers, } \\
82 \quad(65 \%) \\
\text { received at } \\
\text { least } 10 \text { vis- } \\
\text { its, } 34 \\
(27 \%) \text { re- } \\
\text { ceived } \\
\text { between } 5 \\
\text { and } \\
9 \text { visits, and } \\
11 \text { (9\%) re- } \\
\text { ceived } \\
\text { fewer than } \\
5 \text { visits }\end{array}$ & home & individual & Injuries \\
\hline 13 & $\begin{array}{l}\text { Johnston } \\
2004 \\
\text { Johnston } \\
2006 \\
\text { cluster } \\
\text { RCT }\end{array}$ & $\begin{array}{l}\text { pregnant } \\
\text { women }\end{array}$ & Prenatal & 7 & $\begin{array}{l}\text { approx } 7 \\
\text { ( } 3 \text { prenatal } \\
\text { home visits } \\
+4 \text { postna- } \\
\text { tal } \\
\text { home and } \\
\text { office visits) }\end{array}$ & $\begin{array}{l}\text { not } \\
\text { reported }\end{array}$ & $\begin{array}{l}\text { home and } \\
\text { elsewhere }\end{array}$ & $\begin{array}{l}\text { individual } \\
\text { and group }\end{array}$ & $\begin{array}{l}\text { Home } \\
\text { safety* }\end{array}$ \\
\hline 14 & $\begin{array}{l}\text { Kemp } \\
2008 \\
\text { Kemp } \\
2011 \\
\text { RCT }\end{array}$ & $\begin{array}{l}1 \text { or more } \\
\text { of the fol- } \\
\text { lowing } \\
\text { risk factors: } \\
\text { age }<19 \\
\text { years, } \\
\text { cur- } \\
\text { rent proba- } \\
\text { ble distress } \\
\text { (assessed as } \\
\text { an } \\
\text { Edinburgh } \\
\text { Depres- } \\
\text { sion Scale } \\
\text { (EDS) } \\
\text { score of } \\
10+\text { ), } \\
\text { lack of }\end{array}$ & Prenatal & 27 & $\begin{array}{l}\text { approx } 27 \\
\text { (an- } \\
\text { tenatally: at } \\
\text { least every } \\
\text { sec- } \\
\text { ond week; } \\
\text { post natal: } \\
\text { weekly un- } \\
\text { til } 6 \text { weeks; } \\
\text { fortnightly } \\
\text { until } 12 \\
\text { weeks; } \\
\text { monthly to } \\
6 \text { months; } \\
\text { bi monthly } \\
\text { until } 2 \\
\text { years) }\end{array}$ & $\begin{array}{l}\text { mean } 16.3 \\
\text { (range } 0-52 \\
\text { visits) }\end{array}$ & home & $\begin{array}{l}\text { individual } \\
\text { and group }\end{array}$ & $\begin{array}{l}\text { HOME } \\
\text { score }\end{array}$ \\
\hline
\end{tabular}




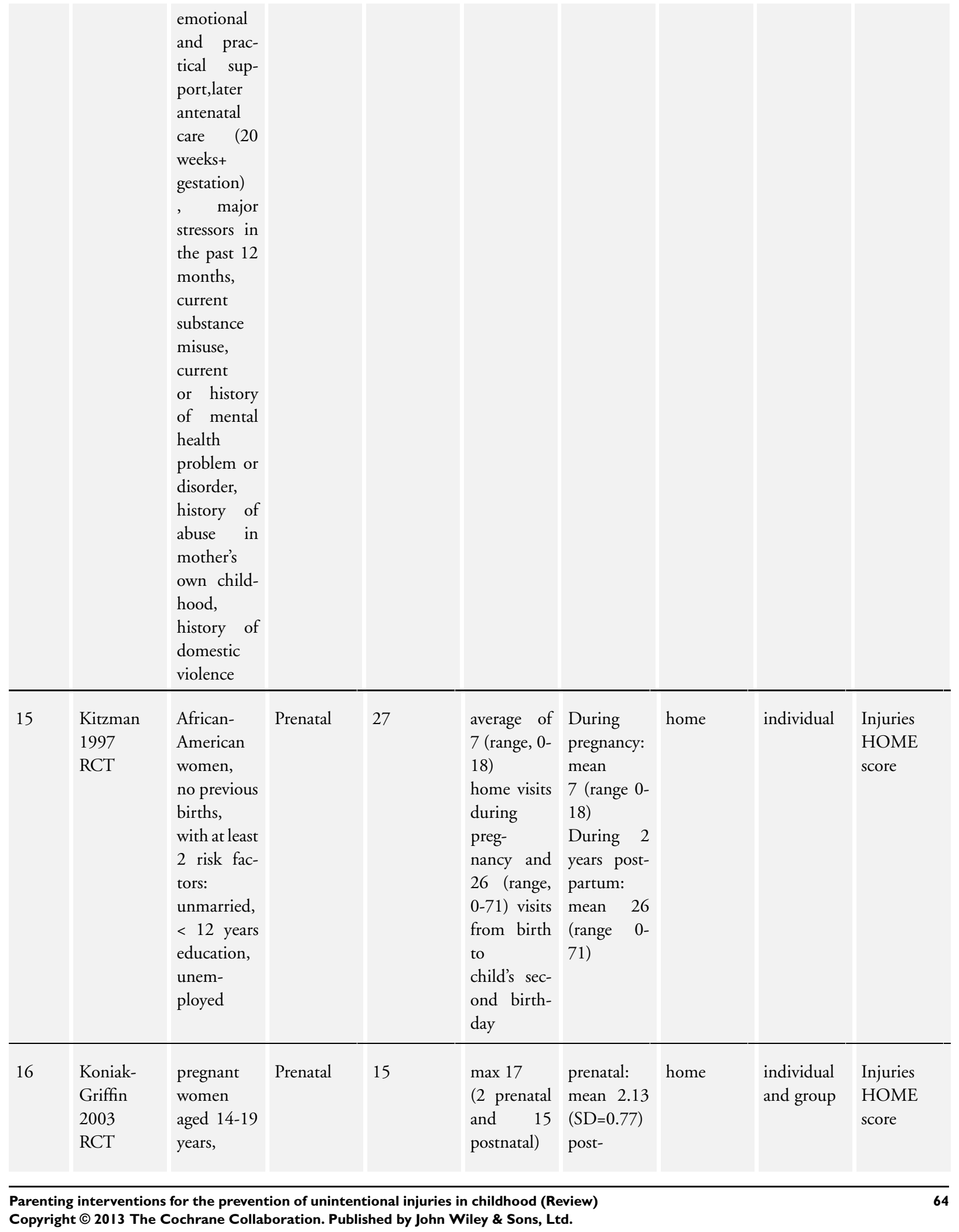


Table 1. Summary of included studies: participant and intervention characteristics

\begin{tabular}{|c|c|c|c|c|c|c|c|c|c|}
\hline & & $\begin{array}{l}\text { first time } \\
\text { mothers }\end{array}$ & & & & $\begin{array}{l}\text { natal: mean } \\
10.35 \\
(\mathrm{SD}=3.04)\end{array}$ & & & \\
\hline 17 & $\begin{array}{l}\text { Larson } \\
1980 \\
\text { partial } \\
\text { RCT }\end{array}$ & $\begin{array}{l}18-35 \\
\text { years, } \\
\text { work- } \\
\text { ing class in- } \\
\text { come, } \\
\text { high school } \\
\text { graduation } \\
\text { or less }\end{array}$ & Prenatal & 18 & $\begin{array}{l}\text { Group A: } 1 \\
\text { prenatal, } 1 \\
\text { postpar- } \\
\text { tum hospi- } \\
\text { tal visit, } 4 \\
\text { visits } \\
1-6 \text { weeks, } \\
5 \text { visits } 6 \\
\text { weeks to } 15 \\
\text { months } \\
\text { Group B: } 7 \\
\text { visits } \\
6 \text { weeks to } \\
6 \text { months, } \\
3 \text { visits } 6- \\
15 \text { months }\end{array}$ & $\begin{array}{l}\text { not } \\
\text { reported }\end{array}$ & home & individual & $\begin{array}{l}\text { Injuries } \\
\text { HOME } \\
\text { score }\end{array}$ \\
\hline 18 & $\begin{array}{l}\text { Llewellyn } \\
2003 \\
\text { RCT }\end{array}$ & $\begin{array}{l}\text { parents } \\
\text { with intel- } \\
\text { lectual dis- } \\
\text { ability }\end{array}$ & $\begin{array}{l}\text { Under } \quad 5 \\
\text { years }\end{array}$ & 3 & 10 weekly & mean 11.5 & home & individual & $\begin{array}{l}\text { Home } \\
\text { safety* }\end{array}$ \\
\hline $\begin{array}{l}19 \\
20\end{array}$ & $\begin{array}{l}\text { Minkovitz } \\
\text { 2003a, } \\
\text { RCT } \\
\text { Minkovitz } \\
\text { 2003b, } \\
\text { cluster } \\
\text { CBA }\end{array}$ & $\begin{array}{l}\text { parents of } \\
\text { newborns }\end{array}$ & $\begin{array}{l}\text { newborns < } \\
4 \text { weeks }\end{array}$ & 36 & $\begin{array}{l}6 \text { home vis- } \\
\text { its in first } 3 \\
\text { years + par- } \\
\text { ent groups }\end{array}$ & $\begin{array}{l}\text { mean home } \\
\text { visits } \\
2 \\
\text { in } 2.5 \text { years } \\
+\quad \text { family } \\
\text { made mean } \\
11 \text { well- } \\
\text { child visits }\end{array}$ & $\begin{array}{l}\text { home and } \\
\text { elsewhere }\end{array}$ & $\begin{array}{l}\text { individual } \\
\text { and group }\end{array}$ & $\begin{array}{l}\text { Injuries } \\
\text { Home } \\
\text { safety* }\end{array}$ \\
\hline 21 & $\begin{array}{l}\text { Olds } 1986 \\
\text { Olds } 1994 \\
\text { RCT }\end{array}$ & $\begin{array}{l}\text { one of the } \\
\text { following } \\
\text { characteris- } \\
\text { tics that } \\
\text { predis- } \\
\text { pose to in- } \\
\text { fant health } \\
\text { and } \\
\text { develop- } \\
\text { mental } \\
\text { problems: } \\
\text { age < } 19 \\
\text { years; sin- } \\
\text { gle parent; }\end{array}$ & Prenatal & 27 & $\begin{array}{l}\text { Interven- } \\
\text { tion } 1 \text { : } \\
\text { free trans- } \\
\text { port to pre- } \\
\text { na- } \\
\text { tal \& well } \\
\text { child vis- } \\
\text { its (0 home } \\
\text { visits); } \\
\text { Interven- } \\
\text { tion 2: } \\
\text { free trans- } \\
\text { port to pre- } \\
\text { na- }\end{array}$ & $\begin{array}{l}\text { Mean vis- } \\
\text { its: } \\
\text { Interven- } \\
\text { tion } 2=9 \\
\text { Interven- } \\
\text { tion } 3=23\end{array}$ & $\begin{array}{l}\text { home and } \\
\text { elsewhere }\end{array}$ & individual & $\begin{array}{l}\text { Injuries } \\
\text { Home } \\
\text { safety* } \\
\text { HOME } \\
\text { score }\end{array}$ \\
\hline
\end{tabular}




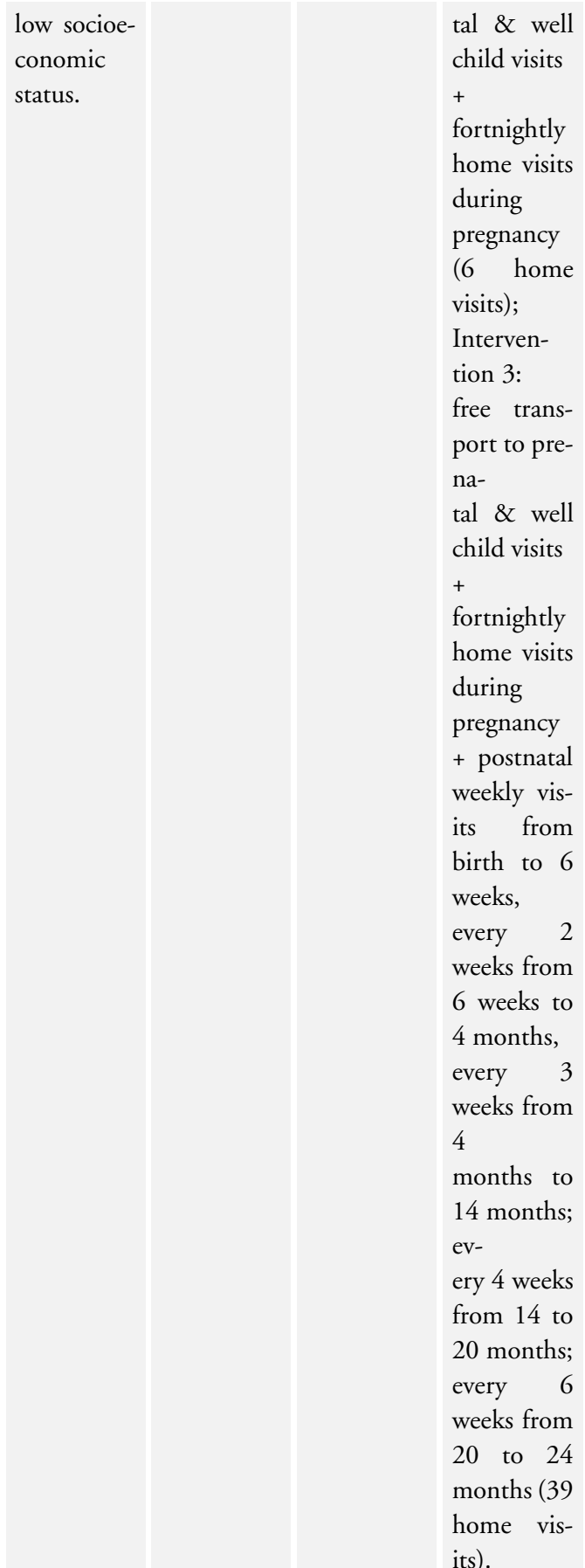

\begin{tabular}{l|l|l|l|}
\hline 22 & St Pierre & woman & Child \\
1999 & pregnant or & $<1$ year \\
& $\begin{array}{l}\text { Goodson } \\
2000\end{array}$ & had a baby & \\
& & \\
\hline
\end{tabular}

60 
Table 1. Summary of included studies: participant and intervention characteristics

\begin{tabular}{|l|l} 
RCT & $<1$ year and \\
a family in- \\
come at or \\
be- \\
low poverty \\
guidelines
\end{tabular}

\begin{tabular}{l|l}
$\begin{array}{l}\text { nightly vis- } \\
\text { its between } \\
\text { ages birth - }\end{array}$ & ilies were in \\
3 years) & pro- \\
& gramme for \\
& 5 \\
& years, $15 \%$ \\
& for 4 years, \\
& $34 \%$ for 1 - \\
& 3 \\
& years, $18 \%$ \\
& $<1$ year
\end{tabular}

*Home safety: includes home safety practices and/or use of home safety equipment and/or home hazards

Table 2. Reporting of HOME scores: total and subscales

\begin{tabular}{|c|c|c|c|c|c|}
\hline & \multirow[t]{2}{*}{ Author, year } & \multirow[t]{2}{*}{ Study design } & \multicolumn{2}{|c|}{$\begin{array}{l}\text { HOME score reported } \\
\text { and when measured }\end{array}$} & \multirow{2}{*}{$\begin{array}{l}\text { Comments (find- } \\
\text { ings reported in text of } \\
\text { the review) }\end{array}$} \\
\hline & & & Total HOME score & $\begin{array}{l}\text { Organisation of the } \\
\text { home environment }\end{array}$ & \\
\hline 1 & Armstrong 2000 & RCT & $\begin{array}{l}6 \text { months } \\
12 \text { months }\end{array}$ & $\begin{array}{l}6 \text { weeks } \\
4 \text { months } \\
12 \text { months }\end{array}$ & \\
\hline 2 & $\begin{array}{l}\text { Barlow } \\
2007\end{array}$ & RCT & $\begin{array}{l}12 \text { months } \\
36 \text { months }\end{array}$ & $\begin{array}{l}12 \text { months } \\
36 \text { months }\end{array}$ & $\begin{array}{l}\text { SD not reported, ob- } \\
\text { tained for } 12 \text { month data } \\
\text { through personal com- } \\
\text { munication }\end{array}$ \\
\hline 3 & $\begin{array}{l}\text { Calder } \\
2007\end{array}$ & RCT & 24 months & & $\begin{array}{l}\text { Reports: } \\
\text { 1. \% with HOME score } \\
\text { < or equal to } 33 \\
\text { 2. total HOME score, no } \\
\text { SD reported }\end{array}$ \\
\hline 4 & $\begin{array}{l}\text { Duggan } \\
1999\end{array}$ & RCT & & & $\begin{array}{l}\text { Does not report total } \\
\text { HOME score or organ- } \\
\text { isation of the environ- } \\
\text { ment subscale }\end{array}$ \\
\hline 5 & $\begin{array}{l}\text { Kemp } \\
2011\end{array}$ & RCT & & $\begin{array}{l}12 \text { months } \\
24 \text { months }\end{array}$ & $\begin{array}{l}\text { Mean and SE reported. } \\
\text { Unclear whether } 12 \text { or } \\
24 \text { month data reported }\end{array}$ \\
\hline 6 & $\begin{array}{l}\text { Kitzman } \\
1997\end{array}$ & RCT & $\begin{array}{l}12 \text { months } \\
24 \text { months }\end{array}$ & & $\begin{array}{l}\text { Mean, mean difference } \\
\text { and } 95 \% \text { CI reported }\end{array}$ \\
\hline
\end{tabular}


Table 2. Reporting of HOME scores: total and subscales (Continued)

\begin{tabular}{|c|c|c|c|c|}
\hline & & & & $\begin{array}{l}\text { adjusted for maternal } \\
\text { psychological resources, } \\
\text { household income and } \\
\text { poverty level of census } \\
\text { tract at } 24 \text { months. No } \\
\text { SD reported }\end{array}$ \\
\hline 7 & $\begin{array}{l}\text { Koniak-Griffin } \\
2003\end{array}$ & RCT & $\begin{array}{l}12 \text { months } \\
24 \text { months }\end{array}$ & $\begin{array}{l}\text { Reports results from An- } \\
\text { cova }\end{array}$ \\
\hline 8 & $\begin{array}{l}\text { Larson } \\
1980\end{array}$ & Partially randomised & $\begin{array}{l}6 \text { weeks } \\
6 \text { months } \\
12 \text { months } \\
18 \text { months }\end{array}$ & $\begin{array}{l}\text { Means and statistical sig- } \\
\text { nificance reported. No } \\
\text { SD reported. }\end{array}$ \\
\hline 9 & $\begin{array}{l}\text { Olds } \\
1986\end{array}$ & RCT & $\begin{array}{l}34 \text { months } \\
46 \text { months }\end{array}$ & No SD reported. \\
\hline 10 & $\begin{array}{l}\text { St Pierre } \\
1999\end{array}$ & RCT & 48 months & $\begin{array}{l}\text { Reports only data at } 48 \\
\text { months }\end{array}$ \\
\hline
\end{tabular}

\section{A P P E N D I C ES}

\section{Appendix I. Search strategy}

Cochrane Injuries Group Specialised Register (searched 24 Jan 2011): 57 records (limit: 2005 to 2011)

1. (child* or infan* or toddl* or pre-school* or preschool* or "pre school" or young* or adolesc* or pediat* or paediat* or minor* or boy* or girl* or teen* or adolesc* or baby or babies)

2. ((accident* AND prevent*) or safety or (safe* AND device*) or (safe* AND equipment*) or (infan* AND equipment*) or (protective AND device*) or injur* or wound* or accident* or fracture* or poison* or suffocat* or asphyx* or drown* or burn* or scald* or lacer* or contus* or $\left(\right.$ smok* $^{*}$ AND inhal $\left.{ }^{*}\right)$ )

3. (parent* AND program*) or (parent* AND train*) or (parent* AND educat*) or (parent* AND promot $\left.{ }^{*}\right)$ or $^{*}$ (parent* AND skill $^{*}$ ) or (parent* AND intervent*) or (parent* AND group*) or (parent* AND support*) or ("parent-child relations" or "parentchild interaction" or "object attachment")

\section{1 and 2 and 3}

Cochrane Central Register of Controlled Trials 2011, issue 1 (The Cochrane Library): 101 records

\#1 ((parent* near3 program*) or (parent* near3 train*) or (parent* near3 educat*) or (parent* near3 promot*) or (parent* $^{*}$ near3 skill*) or (parent* near3 intervent*) or (parent* near3 group) or (parent* near3 support) or (parent-child relations or parent-child interaction or object attachment)):ti, ab

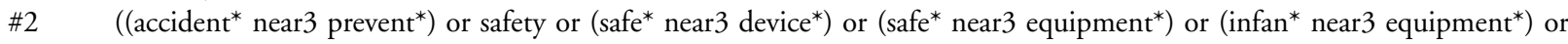

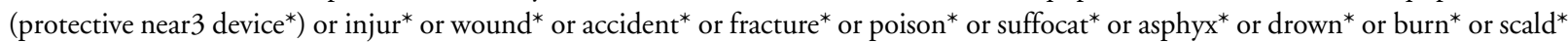
or lacer* or contus* ${ }^{*}$ or $($ smok* near3 inhal*) $): t i, a b^{*}$

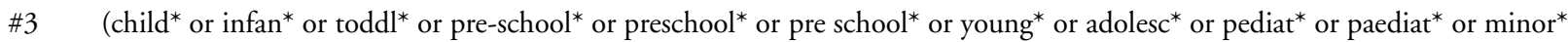
or boy* or girl* or teen* or adolesc* or baby or babies):ti, ab

\#4 (\#1 AND \#2 AND \#3)

MEDLINE (Ovid SP) 1950 to 2011 week 2 (limit: 2005 to 2011): 274 records

Parenting interventions for the prevention of unintentional injuries in childhood (Review)

Copyright $\Subset 2013$ The Cochrane Collaboration. Published by John Wiley \& Sons, Ltd. 
1. (infan\$ or child $\$$ or teen $\$$ or adolesc $\$$ or minor $\$$ or toddl $\$$ or bab $\$$ ).mp.

2. ( $\operatorname{parent} \$ \operatorname{adj} 3 \operatorname{program} \$)$ or (parent $\$ \operatorname{adj} 3 \operatorname{train} \$)$ or (parent $\$ \operatorname{adj} 3$ educat $\$$ ) or (parent $\$ \operatorname{adj} 3$ promot $\$$ ) or $(\operatorname{parent} \$ \operatorname{adj} 3$ skill $\$)$ or (parent $\$$ adj3 intervent $\$$ ) or (parent $\$$ adj3 group) or (parent $\$$ adj3 support) or (parent-child relations or parent-child interaction or object attachment)).mp.

3. ( (accident $\$$ adj3 prevent $\$$ ) or safety or (safe $\$ \operatorname{adj} 3$ device $\$$ ) or (safe $\$$ adj3 equipment $\$$ ) or (infan $\$$ adj3 equipment $\$$ ) or (protective adj3 device $\$$ ) or injur $\$$ or wound $\$$ or accident $\$$ or fracture $\$$ or poison $\$$ or suffocat $\$$ or asphyx $\$$ or drown $\$$ or burn $\$$ or scald $\$$ or lacer $\$$ or contus $\$$ or ( $\operatorname{smok} \$$ adj3 inhal $\$)$ ). mp.

4. (randomised controlled trial or randomized controlled trial or random allocation or double blind method or clinical trial or control group or evaluat $\$$ or intervent $\$$ or comparative study).mp.

5.1 and 2 and 3 and 4

\section{EMBASE (Ovid SP) 1980 to 2011 week 2 (limit:2005 to 2011): 406 records}

1. ((parent* adj3 program*) or (parent* adj3 train*) or (parent* adj3 educat*) or (parent* adj3 promot*) or (parent* adj3 skill*) or (parent ${ }^{*}$ adj3 intervent $t^{*}$ or (parent* adj3 group) or (parent* adj3 support) or (parent-child relations or parent-child interaction or object attachment)).mp.

2. ((accident* adj3 prevent $\left.{ }^{*}\right)$ or safety or $\left(\right.$ safe* $^{*}$ adj3 device*) or (safe* adj3 equipment ${ }^{*}$ ) or (infan* adj3 equipment*) or (protective adj3 device*) or injur* or wound* or accident* or fracture* or poison* or suffocat* or asphyx* or drown* or burn* or scald* or lacer* or contus* or $\left(\right.$ smok $^{*}$ adj3 inhal $\left.\left.{ }^{*}\right)\right)$.mp.

3. (randomised controlled trial or randomized controlled trial or random allocation or double blind method or clinical trial or control group or evaluat* or intervent* or comparative study).mp.

4. (child* or infan* $^{*}$ or toddl ${ }^{*}$ or pre-school* or preschool* $^{*}$ or pre?school* or young* or adolesc $^{*}$ or pediat* or paediat $^{*}$ or minor $^{*}$ or boy* or girl* or teen* or adolesc* or baby or babies).mp.

5. 1 and 2 and 3 and 4

6. 5

7. limit 6 to $\mathrm{yr}=$ "2005 - 2010"

ISI Web of Science: Social Sciences Citation Index (SSCI) 1970 to January 2011 (limit:2005 to 2011) and ISI Web of Science: Conference Proceedings Citation Index- Social Science \& Humanities (CPCI-SSH) -1990 to January 2011(limit:2005 to 2011): 185 records

1. (child* or infan* $^{*}$ or toddl* ${ }^{*}$ or pre-school* or preschool* $^{*}$ or pre school* or young* $^{*}$ or adolesc or pediat* $^{*}$ or paediat* or minor $^{*}$ or boy* or girl* or teen* or adolesc* or baby or babies)

2. ((accident* SAME prevent*) or safety or (safe* SAME device*) or (safe* SAME equipment*) or (infan* SAME equipment*) or (protective SAME device*) or injur* or wound* or accident* or fracture* or poison* or suffocat* or asphyx* or drown* or burn* or scald* or lacer* or contus* or (smok* SAME inhal*))

3. (parent* SAME program*) or (parent* SAME train*) or (parent* SAME educat*) or (parent* SAME promot*) or (parent* SAME skill*$^{*}$ ) or (parent* SAME intervent*) or (parent* SAME group) or (parent* SAME support) or (parent-child relations or parent-child interaction or object attachment)

4. 1 AND 2 AND 3

5. (randomised OR randomized OR randomly OR random order OR random sequence OR random allocation OR randomly allocated $\mathrm{OR}$ at random $\mathrm{OR}$ randomized controlled trial)

6. (controlled clinical trial OR controlled trial OR clinical trial OR placebo)

7. ((singl* OR doubl* OR trebl* OR tripl*) SAME (blind* OR mask*))

8. 5 OR 6 OR 7

9. (human*)

10. 8 AND 9

11. 4 AND 10

\section{CINAHL (EBSCO) 1982 to 24 Jan 2011 (limit:2005 to 2011): 213 records}

S1 (child* or infan* or toddl* or pre-school* or preschool* or pre school* or young* or adolesc* or pediat* or paediat* or minor* or boy* or girl* or teen* or adolesc* or baby or babies)

S2 ((accident* N3 prevent*) or safety or (safe* N3 device*) or (safe* N3 equipment*) or (infan* N3 equipment*) or (protective N3

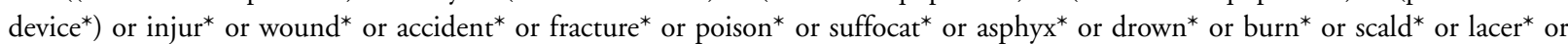
contus* or $\left(\right.$ smok $^{*} \mathrm{~N} 3$ inhal $\left.\left.^{*}\right)\right)$

S3 (parent* N3 program*) or (parent* N3 train*) or (parent* N3 educat*) or (parent* N3 promot*) or (parent* N3 skill*) or (parent* N3 intervent ${ }^{*}$ ) or (parent* N3 group) or (parent* N3 support) or (parent-child relations or parent-child interaction or object attachment)

Parenting interventions for the prevention of unintentional injuries in childhood (Review)

Copyright $\Subset 2013$ The Cochrane Collaboration. Published by John Wiley \& Sons, Ltd. 
S4 S1 and S2 and S3

\section{ASSIA and ERIC}

(infan* or child* or teen* or adolesc* or minor* or toddl* or bab*) and ((parent* within 3 program*) or (parent* within 3 train*) or (parent* within 3 educat $^{*}$ ) or (parent* within 3 promot $^{*}$ ) or (parent ${ }^{*}$ within 3 skill ${ }^{*}$ ) or (parent* within 3 intervent $\left.{ }^{*}\right)$ or $\left(\right.$ parent $^{*}$ within 3 group) or (parent* within 3 support $^{*}$ ) or ((parent-child relations) or (parent-child interaction) or (object attachment)) ) and ((accident* within 3 prevent*) or safety or (safe* within 3 device*) or (safe* within 3 equipment*) or (infan* within 3 equipment*) or (protective within 3 device*) or injur* or wound* or accident* ${ }^{*}$ or fracture* or poison* or suffocat* ${ }^{*}$ or asphyx ${ }^{*}$ or drown* or burn* ${ }^{*}$

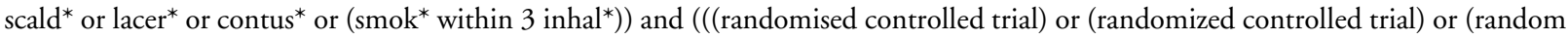
allocation) ) or ((double blind method) or (clinical trial) or (control group)) or (evaluat* or intervent* or (comparative study)))

\section{ProQuest dissertation and thesis}

(infan ${ }^{*}$ or child ${ }^{*}$ or teen ${ }^{*}$ or adolesc ${ }^{*}$ or minor ${ }^{*}$ or toddl ${ }^{*}$ or bab $\left.b^{*}\right) A N D\left(\right.$ arent $\left.{ }^{*}\right) A N D\left(\right.$ injur $^{*}$ or accident or wound $\left.^{*}\right)$ AND (randomi ${ }^{*}$ controlled trial or random* allocation) OR (double blind method) OR (clinical trial or control group) OR (comparative stud* or evalua* or intervent $\left.{ }^{*}\right)$ AND PDN $(>1 / 1 / 2005)$ AND PDN $(<12 / 31 / 2011)$

\section{BIOSIS Preview}

Topic=(infan* OR child* OR teen* OR adolesc* ${ }^{*}$ or minor* OR toddl* OR bab*) AND Topic=(parent* program* OR parent* ${ }^{*}$ train $^{*}$ OR parent* educat* OR parent* promot* OR parent* skill* OR parent* intervent* OR parent* group OR parent* support* OR (parentchild relations OR parent-child interaction OR object attachment)) AND Topic=(injur* OR accident* OR wound* OR fracture* OR safe* OR protect* OR poison* OR suffocat* OR asphyx* OR drown* OR burn* OR scald* OR lacer* OR contus*) AND Topic= ((randomised controlled trial OR randomized controlled trial OR random allocation) OR (double blind method OR clinical trial OR control group) OR (evaluat* OR intervent* OR comparative study))

Databases=PREVIEWS Timespan $=2005-2011$

\section{Sociological Abstracts}

\#1 (infan* ${ }^{*}$ or child* or teen* or adolesc* ${ }^{*}$ or minor* ${ }^{*}$ or toddl* or bab*) and ((((parent-child relations) or (parent-child interaction)) or ((parent-child relations) or (parent-child interaction)) or (object attachment)) and ((accident* or injur* or wound* or accident* or fracture* or poison* or suffocat* or asphyx* or drown* or burn* or scald* or lacer* or contus*) or (safe* or protective*) or (smok* within 3 inhal $\left.\left.{ }^{*}\right)\right)$ and $((($ randomised controlled trial) or (randomized controlled trial) or (random allocation)) or ((double blind method) or (clinical trial) or (control group)) or (evaluat* or intervent* or (comparative study)))

\section{Zetoc}

general: child or infant or baby and parent.

general: parenting intervention and injury.

\section{WHAT'S NEW}

Last assessed as up-to-date: 31 January 2011.

\begin{tabular}{l|l|l}
\hline Date & Event & Description \\
\hline 8 August 2012 & New citation required and conclusions have changed & $\begin{array}{l}\text { The review has been updated with data from seven new } \\
\text { studies. We have now included a meta-analysis of HOME } \\
\text { scores. The results and conclusions have changed (minor) }\end{array}$ \\
\hline 31 January 2011 & New search has been performed & $\begin{array}{l}\text { The search for studies was updated to January 2011. } \\
\text { Seven new studies are included }\end{array}$ \\
\hline
\end{tabular}

Parenting interventions for the prevention of unintentional injuries in childhood (Review) 


\section{CONTRIBUTIONSOFAUTHORS}

DK had the original idea for the review. DK, CM, JM and SS-B drafted the study protocol. LY and CM undertook the searches. LY, $\mathrm{CM}$, TS and DK undertook data extraction. CM undertook the analyses. CM and DK drafted the final review.

\section{DECLARATIONSOF INTEREST}

None known.

\section{SOURCES OF SUPPORT}

\section{Internal sources}

- University of Nottingham, UK.

- University of Warwick, UK.

\section{External sources}

- Department of Health., UK.

- This Cochrane update was funded by the National Institute for Health Research Health Technology Assessment (NIHR HTA) Programme (project number 09/02/02) and a summary will be published in Health Technology Assessment.

- The views and opinions expressed therein are those of the authors and do not necessarily reflect those of the HTA programme, NIHR, NHS or the Department of Health.

\section{DIFFERENCES BETWEEN PROTOCOLANDREVIEW}

1. Types of outcomes measures: we also reported scores on the HOME scale and thus section 3 of "Types of outcomes measures" now reads:

"safety practices (for example, storage of hazardous objects and substances, use of baby walkers, unsafe hot water temperature, etc and composite measures of safety practices including the Home Observation for Measurement of the Environment inventory. The InfantToddler HOME inventory, designed for use with children aged 0 to 3 years, consists of 6 subscales: emotional and verbal responsivity of the primary caregiver (items 1-11); avoidance of restriction and punishment (items 12-19); organisation of the physical and temporal environment (items 20-25) including "the child's play environment appears safe and free of hazards"; provision of appropriate play materials (items 26-34); parental involvement with the child (items 35-40) and opportunities for variety in daily stimulation (items 40-45) (Caldwell 2003; Totsika 2004). A higher score indicates a more appropriate home environment for child development.

In addition, in this update we had sufficient data to undertake a meta-analysis of HOME scores.

2. Websites searched: we also searched "Public Health website (UK)"

3. Quality assessment: in the protocol we stated that we would assess the quality of non-randomised studies using the tool developed by Reisch and colleagues (Reisch, 1989). However we did not use the Reisch tool and thus this section now reads as below.

"The following sources of bias were assessed for non-randomised studies:

- participant selection (selection bias)

- blinding (performance bias and detection bias)

- blinding of participants and personnel (performance bias)

- blinding of outcome assessment (detection bias)

- incomplete outcome data (attrition bias)

Parenting interventions for the prevention of unintentional injuries in childhood (Review) 
- selective reporting (reporting bias)

- risk of bias due to confounding: Was there an assessment of the distribution of confounders between treatment arms? If so, do treatment arms appear similar in terms of confounders?

- other bias."

4. Quality assessment: in addition we have added the following sentence to this section:

"Disagreement between reviewers was dealt with by referral to a third reviewer."

5. Measures of treatment effect: we stated in the protocol that we would pool results and present them as relative risks and $95 \%$ CI for the binary outcomes. We have adjusted this sentence to read:

"Pooled relative risks and 95\% confidence intervals have been used for binary outcome measures and mean differences and $95 \%$ confidence intervals for continuous outcome measures."

6. Data analysis/synthesis: we stated in the protocol that "if there are sufficient studies we will pool results and present them as relative risks and 95\% CI for the binary outcomes of possession of items of safety equipment, safety practices and occurrence of at least one self reported medically attended injury". However in the review we pooled results for self reported medically attended injuries and HOME scores and thus we have written the following sentence in the full review:

"Pooled relative risks and 95\% CI were estimated for occurrence of at least one self reported or medically attended injury. Pooled mean differences and 95\% CI were estimated for HOME scale scores."

7. Primary and secondary analyses: in the protocol we state that "As the review includes both randomised and non-randomised studies the primary analysis will be based on randomised studies with a secondary analysis including both randomised and non-randomised studies". However we have not combined RCT and non RCTs in a single meta-analysis.

Thus in the review under "Data synthesis" we have written "Pooled relative risks and 95\% CI were estimated for occurrence of at least one self reported or medically attended injury using data from included RCTs. Pooled mean differences and 95\% CI were estimated for HOME scale scores using data from included RCTs." and "Where there were insufficient clinically homogenous studies to combine in a meta-analysis or where findings were from non RCTs, their results were combined in a narrative review".

8. Sensitivity analyses: we stated in the protocol that "sensitivity analyses would be undertaken for individual aspects of the study quality as discussed in the section on quality assessment". In the final review we give more precise detail stating:

"Sensitivity analyses have been undertaken including only RCTs considered to be at low risk of selection bias in terms of adequate allocation concealment, detection bias in terms of blinded outcome assessment and attrition bias due to follow up of fewer than $80 \%$ of participants in each arm."

\section{INDEX TERMS}

\section{Medical Subject Headings (MeSH)}

*Accident Prevention; *Parenting; Accidents, Home [prevention \& control]; Protective Devices; Randomized Controlled Trials as Topic; Safety; Wounds and Injuries [* prevention \& control]

Parenting interventions for the prevention of unintentional injuries in childhood (Review) 


\section{MeSH check words}

Adolescent; Child; Child, Preschool; Humans; Infant

Copyright $\odot 2013$ The Cochrane Collaboration. Published by John Wiley \& Sons, Ltd. 